UNIVERSIDADE DE BRASÍLIA

FACULDADE DE AGRONOMIA E MEDICINA VETERINÁRIA PROGRAMA DE PÓS-GRADUAÇÃO EM AGRONOMIA

SELEÇÃO DE ESTIRPES DE Bacillus thuringiensis TÓXICAS À Helicoverpa armigera E PROMOTORAS DE CRESCIMENTO VEGETAL

CARLA FERREIRA CAIXETA

DISSERTAÇÃO DE MESTRADO EM AGRONOMIA 
UNIVERSIDADE DE BRASÍLIA

FACULDADE DE AGRONOMIA E MEDICINA VETERINÁRIA

PROGRAMA DE PÓS-GRADUAÇÃO EM AGRONOMIA

\section{SELEÇÃO DE ESTIRPES DE Bacillus thuringiensis TÓXICAS À Helicoverpa armigera E PROMOTORAS DE CRESCIMENTO VEGETAL}

CARLA FERREIRA CAIXETA

ORIENTADORA: ROSE GOMES MONNERAT

DISSERTAÇÃO DE MESTRADO EM AGRONOMIA

PUBLICAÇÃO: 84/2015

BRASÍLIA/DF

FEVEREIRO/2015 
UNIVERSIDADE DE BRASÍLIA

FACULDADE DE AGRONOMIA E MEDICINA VETERINÁRIA

PROGRAMA DE PÓS-GRADUAÇ̃̃o EM AGRONOMIA

\section{SELEÇÃO DE ESTIRPES DE Bacillus thuringiensis TÓXICAS À Helicoverpa armigera E PROMOTORAS DE CRESCIMENTO VEGETAL}

CARLA FERREIRA CAIXETA

DISSERTAÇÃO DE MESTRAdO SUBMETIDA AO PROGRAMA DE PÓSGRADUAÇÃ̃O EM AGRONOMIA, COMO PARTE DOS REQUISITOS NECESSÁRIOS À OBTENÇÃO DO GRAU DE MESTRE EM AGRONOMIA.

APROVADA POR:

ROSE GOMES MONNERAT, Dra. Pesquisadora Embrapa Recursos Genéticos e Biotecnologia (Orientadora)/CPF 512.803.701-06/e-mail: rose.monnerat @ embrapa.br

MARIA LUCRÉCIA GEROSA RAMOS, Dra. Professora Adjunto unB - FAV (Examinador Interno)/ CPF: 002.094.438-12/ e-mail: lucrecia@unb.

CARLOS MARCELO SILVEIRA SOARES, Dr. Pesquisador Instituto Mato-Grossense do Algodão - IMA-MT (Examinador Externo)/CPF: 490.618.600-91/e-mail: carlosmarcelo@imamt.com.br

BRASÍLIA/DF, 27 DE FEVEREIRO DE 2015 


\section{FICHA CATALOGRÁFICA}

Caixeta, Carla Ferreira.

Seleção de estirpes de Bacillus thuringiensis tóxicas à Helicoverpa armigera $\mathrm{e}$ promotoras de crescimento vegetal. Carla Ferreira Caixeta; orientação de Rose Gomes Monnerat - Brasília, 2015.

82 p. : il.

Dissertação de Mestrado (M) - Universidade de Brasília/Faculdade de Agronomia e Medicina Veterinária, 2015.

1.Controle biológico 2. Metabólito secundários 3. Diversidade genética.

I. Monnerat, R. II. Seleção de estirpes de Bacillus thuringiensis tóxicas à Helicoverpa armigera e promotoras de crescimento vegetal.

\section{REFERÊNCIA BIBLIOGRÁFICA}

CAIXETA, C. F. Seleção de estirpes de Bacillus thuringiensis tóxicas à Helicoverpa armigera e promotoras de crescimento vegetal. Brasília: Faculdade de Agronomia e Medicina Veterinária, Universidade de Brasília, 2015, 82 p. Dissertação de Mestrado.

\section{CESSÃO DE DIREITOS}

NOME DO AUTOR: Carla Ferreira Caixeta

TÍTULO DA DISSERTAÇÃO: Seleção de estirpes de Bacillus thuringiensis tóxicas à Helicoverpa armigera e promotoras de crescimento vegetal.

GRAU: Mestre ANO: 2015

É concedida à Universidade de Brasília permissão para reproduzir cópias desta dissertação de mestrado para única e exclusivamente propósitos acadêmicos e científicos. $\mathrm{O}$ autor reserva para si os outros direitos autorais, de publicação. Nenhuma parte desta dissertação de mestrado pode ser reproduzida sem a autorização por escrito do autor. Citações são estimuladas, desde que citada à fonte.

Nome: Carla Ferreira Caixeta

CPF: 071.076.756-05

Endereço: SCRN 708/709 bloco H entrada 37 apto 202 - Asa norte - Brasília/DF

CEP: 70.741-680

Tel: (61) 8108-3610 / e-mail: carlacaixeta@ hotmail.com 
DEDICO

À Deus por ter me concedido as forças necessárias, a perseverança e a fé para realização e concretização deste trabalho. Aos meus pais faço de minha conquista o instrumento de gratidão, respeito, amor, carinho, compreensão e reconhecimento que recebi $e$ 


\section{AGRADECIMENTOS}

À Deus, por me guiar por caminhos que às vezes pareceram incertos, mas que no final sempre foram as melhores escolhas.

Agradeço à minha orientadora, Dra. Rose Monnerat, pela oportunidade, confiança e pelo privilégio de fazer parte de sua equipe de pesquisa.

À Dra. Lílian Praça e Dra. Bárbara Eckstein pela amizade, paciência e contribuições nos trabalhos.

Ao Dr. Paulo Queiroz pelo incentivo, disponibilidade e por toda ajuda.

Ao Dr. Marcelo Soares pelo apoio, incentivo e por aceitar participar da banca examinadora.

À Dra. Érica, Érica, Eriqueta, mamãe da Lalá, você é um exemplo de pessoa, professora, pesquisadora e mãe, um anjo que apareceu e me mostrou um caminho novo. Muito, muito Obrigada!!!

Ao Elias pela amizade e imensa contribuição neste trabalho.

A todos os colegas e funcionários do Prédio de Controle Biológico, em especial ao Helinho, Isabella, Daniela, Willian, Zilda, Débora, Renata, Pedro, Márcio, Saluana pela ajuda indispensável e amizade.

Aos que estão na equipe LBE e LCPI, Neila, Rayane, Sandro, Marcelo Castro, Laura, Zezinho, Flávia, Briana, Anabele, Mayco, Raul, Gabriel, Fernanda, e aos que já seguiram os seus caminhos, mas que sempre me proporcionaram momentos de descontração, mesmo nas horas mais estressantes de trabalho, sempre tem um que nos faz sorrir.

À Zonaite, Jório, Marina e Ester pela amizade e por toda a ajuda nas avaliações, foi essencial.

Aos professores do Programa de Pós-graduação da FAV por todo ensinamento repassado. Em especial a Prof. ${ }^{\text {a }}$ Cristina Schetino por me proporcionar um crescimento profissional e pessoal, sempre muito bom conversar com você. Ao Prof. Cícero Celio e Ernandes Rodrigues pelo apoio e atenção.

À Prof. Maria Lucrécia por aceitar participar da banca examinadora e por suas colaborações desde a qualificação.

Aos meus colegas de Pós-graduação, em especial ao Alex Cortês, Alejandra Ortega, Flívia Fernandes, Sabrina Navas e Silas que foram o meu apoio dentro e fora da sala de aula, por todas as risadas e conversas incentivadoras.

À Marla e Cris pela amizade, por longas conversas, risadas e agradável convivência. 
Aos meus amores:

Minha mãe Célia por ser a inspiração que me faz querer ser melhor a cada dia e nunca me deixar abater nas dificuldades. Obrigada por nunca me deixar desistir!!

Meu pai Randolfo que desde nova me ensinou a ser responsável e dedicada ao trabalho, sei que nunca quis me deixar voar, mas hoje sabe que foi o melhor.

Meu irmão Adriano por toda ajuda, sem você eu não conseguiria.

Aos meus Avós, Tios, Tias, Primas, Primos e Adriane, muito obrigada por compreenderem a minha ausência e me apoiarem sempre.

As minhas madrinhas Gisele e Sandra, minhas mães!! Muito obrigada por todo amor, carinho e por comemorarem comigo todas as minhas conquistas, simplesmente por comporem uma das melhores partes de mim, mesmo a distância.

Amo muito vocês!!

À Joana, Paulinha, Sol, Márcia, Alisson, Sarah, Paulo, Matheus, Ivan, Augusto, Rosana,

Célio e, a toda a equipe que é muito grande, muito obrigada pela amizade e por todos os momentos de descontração e palavras de incentivo.

As minha amigas Alessandra, Fernandinha e Flavinha, que mesmo longe me apoiaram e incentivaram os meus sonhos. Que essa amizade complete mais décadas, enfim que seja para sempre.

À CAPES pela concessão da bolsa de estudos.

Enfim, a todos que direta ou indiretamente ajudaram no desenvolvimento e finalização deste trabalho.

MUITO OBRIGADA!!

A certeza de que estamos apenas começando,

A certeza de que é preciso continuar

E a certeza de que podemos ser interrompidos antes de terminar.

Fazer da interrupção um caminho novo,

Fazer da queda um passo de dança,

Fazer do medo uma escada,

Fazer do sonho a ponte."

(Fernando Sabino) 


\section{ÍNDICE GERAL}

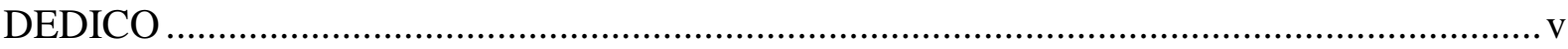

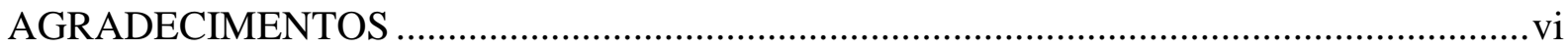

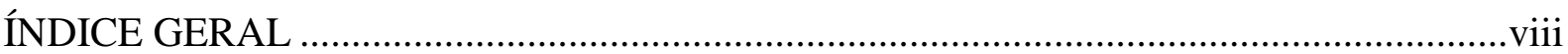

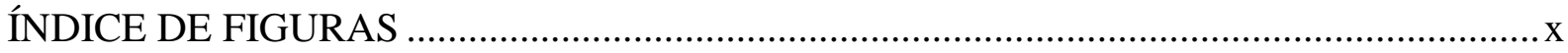

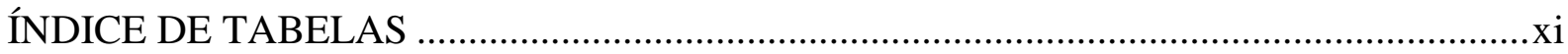

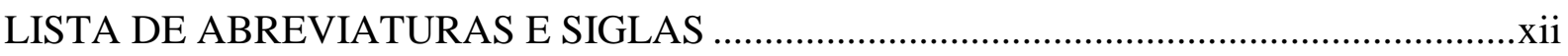

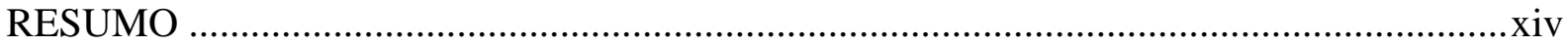

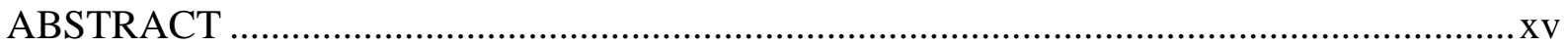

1 INTRODUÇÃ

2 REVISÃO

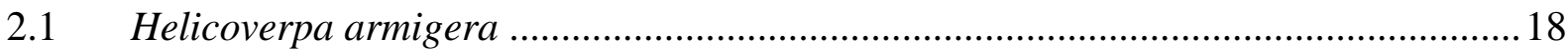

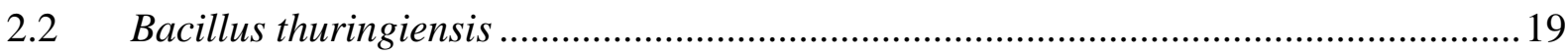

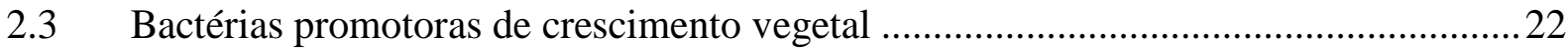

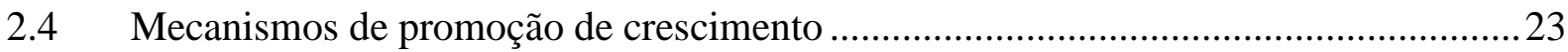

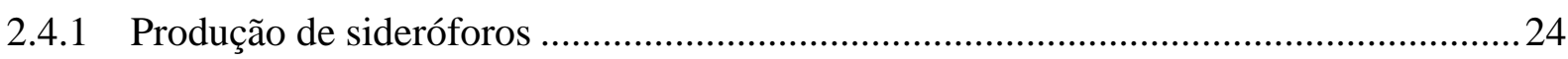

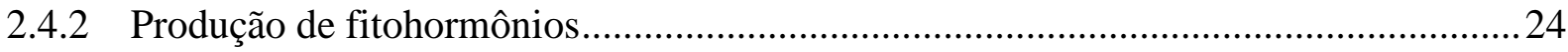

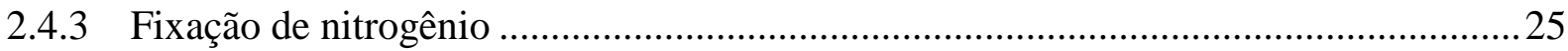

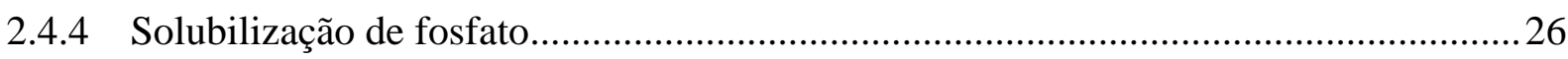

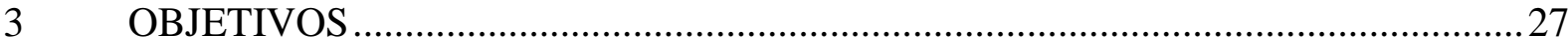

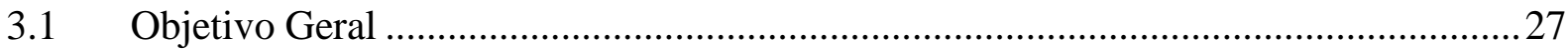

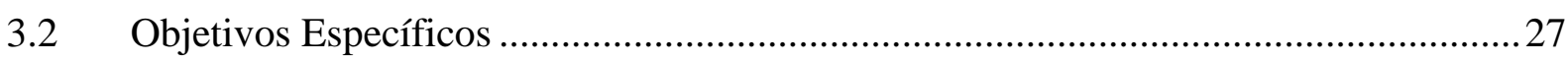

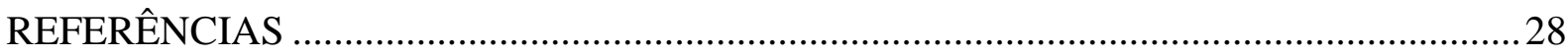

CAPÍTULO ÚNICO - SELEÇÃO DE ESTIRPES DE Bacillus thuringiensis TÓXICAS À Helicoverpa armigera E PROMOTORAS DE CRESCIMENTO VEGETAL .........................37

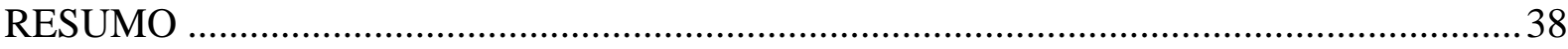

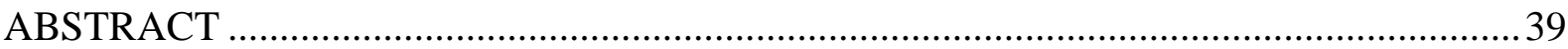

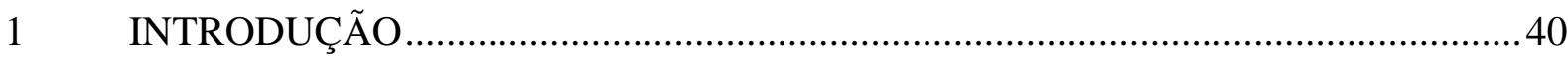

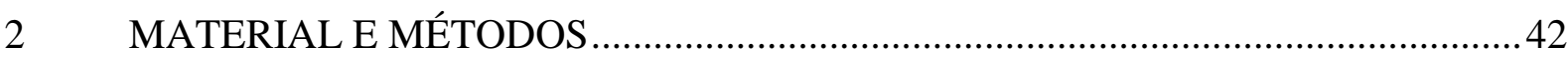

2.1 Determinação da toxicidade de $B$. thuringiensis à $H$. armigera ..................................42 
2.1.1 Criação massal de Helicoverpa armigera ............................................................... 42

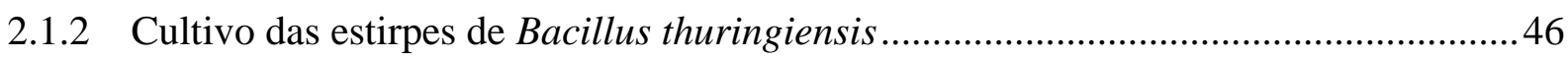

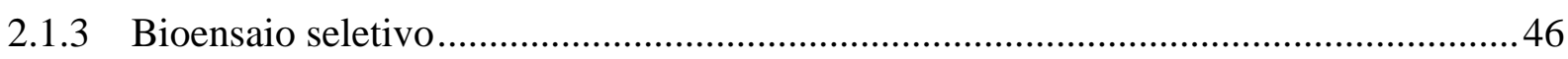

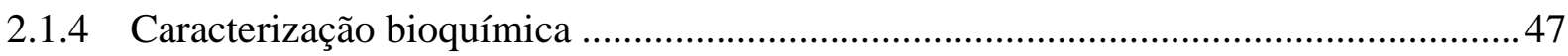

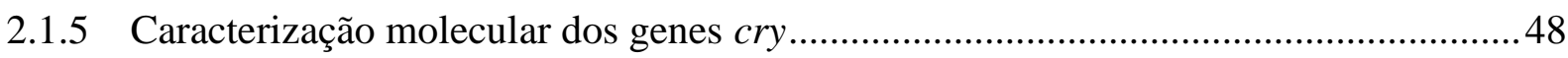

2.2 Determinação da capacidade de promoção de crescimento por estirpes de $B$.

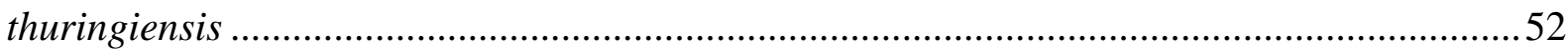

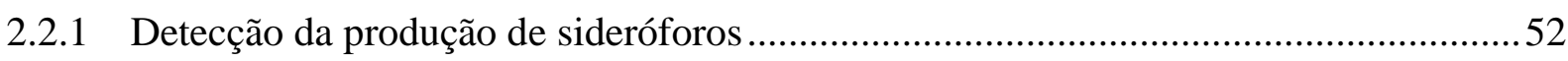

2.2.2 Detecção e quantificação da produção de ácido indol-acético (AIA) ..........................52

2.2.3 Detecção da solubilização de fosfato inorgânico ........................................................53

2.2.4 Detecção da capacidade de fixação assimbiótica de nitrogênio ...................................53

2.2.5 Detecção de genes relacionados ao metabolismo de crescimento vegetal. ..................54

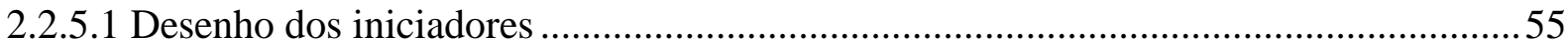

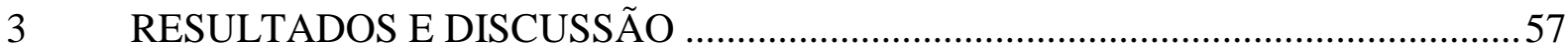

3.1 Criação massal de Helicoverpa armigera ....................................................................57

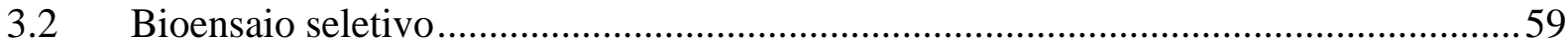

3.3 Caracterização bioquímica e molecular de genes cry das estirpes de B. thuringiensis 62

3.4 Determinação da capacidade de promoção de crescimento por estirpes de $B$.

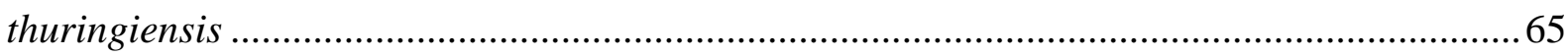

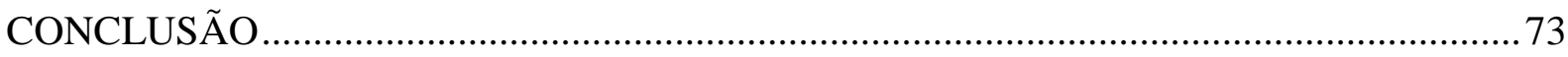

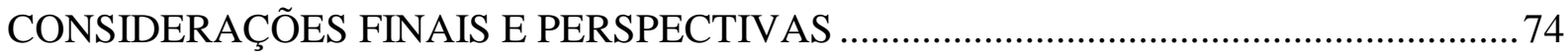

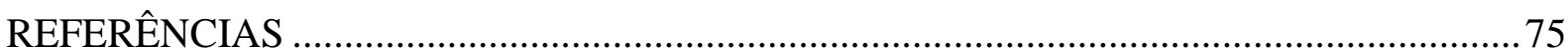




\section{ÍNDICE DE FIGURAS}

Figura 1 - Esquema do modo de ação de toxinas Cry para lepidópteros. .................................21

Figura 2 - Pupas de fêmeas e de machos de $H$. armigera .......................................................4

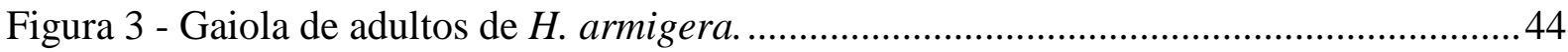

Figura 4 - Barbante de algodão perdurado na parte superior da gaiola para realização das posturas de $H$. armigera.

Figura 5 - Lagartas de $H$. armigera individualizadas em copos plásticos com tampa contendo dieta artificial. 46

Figura 6 - Placa de cultura de células com 24 poços com dieta artifical de $H$. armigera ........ 47

Figura 7 - Vias dependentes de triptofano para biossíntese de AIA. ......................................55

Figura 8 - Padrão de RFLP-PCR digerido com a enzima BstZ17I. .......................................57

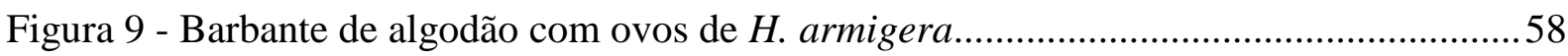

Figura 10 - Lagartas de H. armigera de diferentes colorações. ..............................................58

Figura 11 - Mariposas de H. armigera - fêmea (esquerda) e macho (direita). .......................59

Figura 12 - Perfil protéico das estirpes selecionadas de B. thuringiensis.................................62

Figura 13 - Produtos de PCR obtidos para o gene fosfatase ácida ........................................... 70

Figura 14 - Produtos de PCR obtidos para o gene biossíntese de sideróforos .........................71

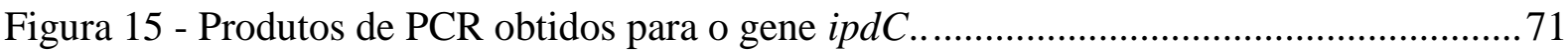




\section{ÍNDICE DE TABELAS}

Tabela 1- Ingredientes autoclaváveis para a dieta artificial para alimentação das lagartas de $H$. armigera

Tabela 2 - Ingredientes não autoclaváveis para a dieta artificial para alimentação das lagartas de H. armigera

Tabela 3 - Dieta líquida para alimentação dos adultos de $H$. armigera

Tabela 4 - Características dos iniciadores utilizados para a detecção dos genes cry em estirpes de B. thuringiensis

Tabela 5 - Característica dos iniciadores utilizados para detecção dos genes fosfatase ácida (metabolismo de solubilização de fosfato); sideróforos (capacidade de produzir complexos com ferro) e iam1, iam2 e ipdC (produção de ácido indol-acético) em estirpes de $B$. thuringiensis

Tabela 6- Característica dos iniciadores desenhados para a detecção dos genes iam1, iam2 e ipdC em estirpes de $B$. thuringiensis 56

Tabela 7 - Resultados de bioensaio seletivo contra H. armigera 60

Tabela 8 - Estirpe, sorotipo, conteúdo gênico e perfil protéico das estirpes de $B$. thuringiensis que apresentaram $100 \%$ de mortalidade à $H$. armigera

Tabela 9 - Caracterização bioquímica das estirpes de $B$. thuringiensis na produção de metabolitos secundários com capacidade de promoção de crescimento vegetal 65 Tabela 10 - Caracterização molecular das estirpes de B. thuringiensis para a presença dos genes de promoção de crescimento vegetal 68 


\section{LISTA DE ABREVIATURAS E SIGLAS}

\begin{tabular}{|c|c|}
\hline$\%$ & Porcentagem \\
\hline \pm & Mais ou menos \\
\hline${ }^{\circ} \mathrm{C}$ & Graus Celsius \\
\hline$\mu \mathrm{g} \mathrm{ml}^{-1}$ & Microgramas por mililitro \\
\hline atm & Pressão atmosférica \\
\hline $\mathrm{Bt}$ & Bacillus thuringiensis \\
\hline $\mathrm{CaCl}_{2}$ & Cloreto de cálcio \\
\hline $\mathrm{CaHPO}_{4}$ & Fosfato de cálcio \\
\hline DNA & Ácido desoxirribonucleico \\
\hline dNTP & Deoxinucleotídeos \\
\hline EDTA & Ácido etilenodiamino tetracético \\
\hline $\mathrm{FeCl}_{3}$ & Cloreto de Ferro III \\
\hline g & Grama \\
\hline K2HPO4 & Fosfato de potássio dibásico \\
\hline $\mathrm{kDa}$ & Quilodalton \\
\hline $\mathrm{L}$ & Litro \\
\hline M & Molar \\
\hline $\mathrm{mA}$ & Miliampère \\
\hline $\mathrm{mg}$ & Miligrama \\
\hline $\min$ & Minuto \\
\hline $\mathrm{mL}$ & Mililitro \\
\hline $\mathrm{mm}$ & Milímetro \\
\hline $\mathrm{mM}$ & Milimolar \\
\hline $\mathrm{mm}$ & Milímetro \\
\hline $\mathrm{NaCl}$ & cloreto de sódio \\
\hline $\mathrm{pb}$ & Pares de bases \\
\hline PCR & Reação em cadeia da polimerase \\
\hline PGPR & Plant growth promoting rhizobacteria \\
\hline PMSF & Fenilmetilsulfonil fluoride \\
\hline RFLP & Restriction Fragment Length Polymorphism \\
\hline
\end{tabular}


rpm

$\mathrm{S}$

SDS

SDS-PAGE

$\mathrm{Tm}$

Tris- $\mathrm{HCl}$

TSL

$\mathrm{V}$

$\beta$

$\delta$

$\mu \mathrm{L}$ rotação por minuto

Segundo

Dodecilsulfato de sódio

Eletroforese em gel de poliacrilamida desnaturado com SDS

Temperatura de anelamento

Tris aminometano-ácido clorídrico

tripticaseína de soja líquido

Volt

Beta

Delta

Microlitro 


\section{RESUMO}

Helicoverpa armigera (Hübner, 1808) (Lepidoptera: Noctuidae) é uma espécie extremamente polífaga, se alimenta das mais diferentes culturas de interesse econômico e tem grande adaptabilidade às várias condições climáticas consideradas uma praga de importância. Bacillus thuringiensis (Bt) é uma bactéria cosmopolita que expressa diversas proteínas durante seus estágios de crescimento que possuem atividade entomopatogênica, podendo atuar como importante agente de controle biológico, além de ser capaz de colonizar o interior das plantas promovendo o seu crescimento. Com a necessidade de se conhecer cada vez mais e explorar as potencialidades deste microrganismo o estudo objetivou selecionar 100 estirpes de Bacillus thuringiensis com toxicidade para Helicoverpa armigera e potencial para promoção de crescimento vegetal. Das estirpes avaliadas 23 apresentaram $100 \%$ de mortalidade para $H$. armigera, sendo quinze pertencentes às subsp. kurstaki, aizawai, tolworthi, fokuokaensis, sotto, morrisoni, thuringiensis e oito não sorotipadas. As estirpes apresentam perfil proteíco de 130 e $65 \mathrm{kDa}$, sendo que algumas apresentaram apenas uma das proteínas e fragmentos de DNA de tamanho esperado para a detecção dos genes cryl e cry2. $\mathrm{Na}$ detecção da capacidade de promoção de crescimento in vitro, nenhuma estirpe apresentou a capacidade de produção de sideróforos, solubilização de fosfatos e fixação biológica de nitrogênio. Na produção de AIA todas as estirpes foram positivas e a quantidade variou de $1,17 \mu \mathrm{g} \mathrm{mL}^{-1}$ (estirpe S93) a 7,44 $\mu \mathrm{g} \mathrm{mL}^{-1}$ (estirpe S1983). Das 100 estirpes analisadas 45 apresentaram amplicons esperados para todos os genes avaliados, sendo que 71 estirpes apresentaram amplicons de tamanhos esperados para o gene fosfatase ácida, 57 foram positivos para os genes sideróforos. Os genes envolvidos nas rotas de biossíntese do hormônio AIA se mostraram mais frequentes em estirpes de $\mathrm{Bt}$, sendo que das estirpes analisadas 91 foram positivos para a presença do gene ipdC, 97 para o genes iaml e 93 para o gene iam2. B. thuringiensis pode ser utilizado no controle de $H$. armigera e possui potencial como inoculante para a promoção de crescimento vegetal, abrindo novas perspectivas para o uso agronômico.

Palavras-chave: controle biológico, metabólitos secundários, diversidade genética. 


\begin{abstract}
Helicoverpa armigera (Hübner, 1808) (Lepidoptera: Noctuidae) is an extremely polyphagous species, feeding from different types of crops with economic importance and has great adaptability to various climatic conditions, considered an important pest. Bacillus thuringiensis is a cosmopolitan bacteria that express different proteins during their growth stages with entomopathogenic activity, and may act as an important biological control agent, besides being capable to colonize the interior of plants, promoting its growth. To know more and explore the potentials of this microorganism, the aimed of this work to select 100 strain of Bacillus thuringiensis wich toxicity to Helicoverpa armigera and potential for plant growth promotion. 23 strains showed $100 \%$ the mortality against $H$. armigera, of which fifteen belonged to subsp. kurstaki, aizawai, tolworthi, fokuokaensis, sotto, morrisoni, thuringiensis and eight without serotype. Some strains exhibited the profile of 130 and $65 \mathrm{kDa}$, other showed just one of the proteins and the amplicons with the expected size of cryl and cry 2 gene. In vitro detection of growth promotion capability, showed that no strain had the siderophore production capability, phosphate solubiliation and biological fixation of nitrogen. All strains tested were capable of produce IAA, and the amount varied from $1,17 \mu \mathrm{g} \mathrm{mL}^{-1}$ (S93 strain) to $7,44 \mu \mathrm{g} \mathrm{mL}^{-1}$ (1983 strain). 45 of the 100 analyzed strains showed the expected amplicons for all the studied genes, 71 strains showed the expected amplicon size for the acid phosphatase gene, 57 were positive for siderophore gene. The genes involved in the biosynthesis of IAA hormone were more frequents in Bt strains, 91 strains were positive for the presence of $i p d C$ gene, 97 were positive for iaml gene, and 93 for iam 2 gene. $B$ thuringiensis can be used in biological control against $H$. armigera and has a great potencial to promote plant growth, creating new perspectives for agronomic use.
\end{abstract}

Keywords: Biological control, secondary metabolite, genetic diversity. 


\section{INTRODUÇÃO}

O Brasil apresenta um papel de destaque no cenário mundial pela quantidade e qualidade de sua produção agrícola. Baseada no modelo convencional utiliza de forma intensiva, fertilizantes químicos e agrotóxicos, o que torna o País um dos maiores consumidores de insumos agrícolas no mundo.

Impulsionada pelo ambiente favorável, com duas safras em um ano em algumas regiões, associado à melhoria da fertilidade dos solos, à irrigação e ao desenvolvimento de plantas melhor adaptadas, a agricultura brasileira experimentou uma grande expansão na última década. Todavia, esse crescimento não foi acompanhado pela indústria brasileira de insumos agrícolas, tornando o País ainda mais dependente da importação de fertilizantes e agrotóxicos. Essa situação torna os produtores quase reféns do mercado internacional, que estabelece os preços, bem como as quantidades de fertilizantes a serem disponibilizadas.

Caracterizado pelo monocultivo realizados em extensas áreas, o sistema de produção agrícola do Brasil favorece o surgimento de elevados níveis populacionais de vários insetos, os quais pelos prejuízos econômicos ocasionados passaram a ser considerados pragas.

Detectada na safra 2012/2013, mas provavelmente com introdução anterior a essa data, Helicoverpa armigera, até então considerada uma praga quarentenária $\mathrm{A} 1$, rapidamente obteve o status de praga e causou perdas econômicas significativas em vários estados brasileiros, principalmente no oeste da Bahia. Espécie polífaga, tem preferência em se alimentar das estruturas reprodutivas das plantas, como flores, inflorescências, frutos e vagens. Todavia, também ataca brotos, folhas e caules. No Brasil, há registro de sua ocorrência em cultivos de algodão, soja, milho, tomate e citros.

$\mathrm{Na}$ tentativa de reduzir os danos ocasionados pela $H$. armigera, o MAPA liberou em 2013, em caráter emergencial, diversos produtos fitossanitários, dentre eles o benzoato de emamectina, inseticida de classe toxicológica I, produto extremamente tóxico e altamente perigoso ao meio ambiente. $\mathrm{O}$ emprego desse e de outros inseticidas convencionais impactam na elevação de custos de produção e podem degradar recursos naturais, contaminado o solo e a água e comprometendo a fauna benéfica como polinizadores e inimigos naturais das pragas.

$\mathrm{O}$ cenário acima descrito estimula o desenvolvimento de novas abordagens, que venham a auxiliar a agricultura brasileira, mas que não impliquem na geração de mais dependência externa ou aumentem os já severos impactos ambientais. Neste contexto, o emprego de Bacillus thuringiensis, uma bactéria entomopatogênica e que também tem a capacidade de estimular o crescimento de plantas como já demonstrado em alface (GOMES et 
al., 2014), leguminosas (TANUJA et al., 2003), amendoim (WANG et al., 2014) e ainda como inseticida sistêmico (PRAÇA et al., 2012) pode vir a ser uma alternativa interessante.

O presente trabalho tem por objetivo selecionar estirpes de B. thuringiensis, que além de serem tóxicas à $H$. armigera, apresentem potencial para promover o crescimento vegetal. 


\section{REVISÃO}

\subsection{Helicoverpa armigera}

Helicoverpa armigera (Hübner, 1808) (Lepidoptera: Noctuidae) apresenta ampla distribuição geográfica, sendo registrada na Europa, Ásia, África, Oceania (GUO, 1997; AVILLA et al, 2005; VASSAL et al., 2008). Na safra 2012/13 foi identificada no Brasil, nos estados da Bahia, Goiás, Mato Grosso e São Paulo (CZEPAK et al., 2013; SPECHT et al., 2013; BUENO et al., 2014).

Essa espécie é extremamente polífaga, registrada como um inseto prejudicial em 181 espécies de plantas cultivadas e silvestres em pelo menos 45 famílias (SRIVASTAVA et al., 2010). Alimenta-se das mais diferentes culturas de interesse econômico, como milho, soja, algodão, tomate (AVILLA et al, 2005; VASSAL et al., 2008), feijão, sorgo, milheto, feijão guandu, trigo (ÁVILA et al, 2013) e citros (BUENO et al., 2014). Devido a sua preferência pelas partes reprodutivas e sua habilidade de atacar um grande número de hospedeiros, recebeu o status de praga de importância econômica (CUNNINGHAM et al., 1999).

É uma espécie que apresenta grande mobilidade, podendo o adulto alcançar uma distância de até $1000 \mathrm{~km}$ com seus voos (PEDGLEY, 1985). Além de possuir alta capacidade de sobrevivência, podendo completar várias gerações ao ano, pois seu período de ovo a adulto dura de quatro a seis semanas (FITT, 1989). Este fato pode ser atribuído à sua fertilidade elevada, comportamento de migração, elevada adaptabilidade a várias condições climáticas e do desenvolvimento de resistência à ampla gama de inseticidas (NASERI et al., 2010).

$\mathrm{Na}$ fase adulta, as fêmeas de H. armigera são capazes de ovipositar de 1000 a 1500 ovos num período de 12 a 15 dias. As mariposas preferem a face superior das folhas ou superfícies mais ásperas e os ovos são colocados isolados (SRINIVASAN et al., 2013).

O período larval dura de 13 a 25 dias e é composto por 5 estádios. As lagartas variam da cor verde ao preto e com listras brancas longitudinais. No último estádio as lagartas deixam a parte aérea e migram para o solo, onde empupam (CZEPAK et al., 2013).

As lagartas de $H$. armigera se alimentam de folhas e caules, porém, têm preferência por brotos, inflorescências, frutos e vagens (WANG \& LI, 1986).

Os inseticidas químicos são largamente utilizados nos ambientes agrícolas como uma alternativa rápida (ÁVILA, et al., 2013), com o intuito de ajudar os produtores a controlar em caráter emergencial o Ministério da Agricultura, Pecuária e Abastecimento (MAPA) no início de 2013, liberou o inseticida benzoato de emamectina. 
O controle de $H$. armigera pode ser realizado por outros métodos e não somente com produtos químicos (ÁVILA, et al., 2013). Produtos formulados a base de Bacillus thuringiensis são uma alternativa promissora contra este inseto, pois sua atividade entomopatogênica já foi comprovada contra vários insetos da ordem Lepidoptera, podendo ser mais um método utilizado no manejo desta praga.

Como H. armigera era considerada uma praga exótica para o Brasil, pesquisas direcionadas a avaliação da suscetibilidade as toxinas de B. thuringiensis são importantes a fim de auxiliar na escolha de um produto eficiente.

\subsection{Bacillus thuringiensis}

B. thuringiensis (Berliner, 1911) (Bt) é uma bactéria Gram positiva, aeróbia, pertencente à família Bacillaceae. Pode ser encontrada no mundo todo, e nos mais diferentes substratos como solo, água, insetos mortos, superfície de plantas (BRAVO et al., 1998) e no interior das raízes (MONNERAT el al., 2003).

A organização entre várias estirpes de B. thuringiensis foi proposto por Barjac \& Bonnefoi (1962) agrupando taxonomicamente por sorotipos ou subespécies, baseada em propriedades bioquímicas, na reação de aglutinação de antígenos flagelares das células vegetativas.

Durante seu crescimento as estirpes de $B$. thuringiensis produzem diferentes fatores de virulência, como as $\delta$-endotoxinas, Vip, $\alpha$-exotoxina, $\beta$-exotoxina, hemolisinas, enterotoxinas, quitinases e fosfolipases (HOFTE \& WHITELEY, 1989; HANSEN \& SALAMITOU, 2000).

As protoxinas "Vip" (do inglês: Vegetative Insecticidal Proteins) são proteínas produzidas e liberadas durante a fase inicial do crescimento das bactérias, por não formarem cristais protéicos foram excluídas da nomenclatura Cry (ESTRUCH et al., 1996). As toxinas binárias, Vip1 e Vip2 atuam no controle de algumas espécies das ordens Coleoptera (WARREN, 1997) e Hemiptera (SAMPURNA \& MAITI, 2011); as proteínas da família Vip3A controlam algumas espécies da ordem Lepidoptera (ESTRUCH et al., 1996).

O modo de ação das proteínas Vip3A ainda estudado mostra ter atuação no epitélio intestinal do inseto assim como as proteínas Cry. Devido sua forma solúvel, essas se ligam mais rapidamente aos receptores da membrana das células epiteliais do intestino dos insetos susceptíveis, resultando na degeneração da camada epitelial (YU et al., 1997). A proteína Vip3A quando ativada liga-se aos receptores localizados nas microvilosidades das células colunares do epitélio intestinal das lagartas susceptíveis (BRAVO et al., 2005). 
As $\delta$-endotoxinas são formadas durante a fase estacionária do seu ciclo de crescimento na forma de inclusões protéicas cristalinas (BRAVO et al., 2005) ou também chamadas de toxinas Cry ou Cyt, sendo estas as responsáveis pela atividade entomopatogênica desta bactéria (MONNERAT \& BRAVO, 2000; BRAVO et al., 2005).

As proteínas Cry estão classificadas em 73 grupos organizados em diferentes subgrupos, que são codificadas por 630 genes cry já sequenciados, além dos três grupos de toxinas Cyt que são codificadas por 11 genes cyt. Estas proteínas são agrupadas em função do grau de identidade de seus aminoácidos e sua atualização constate pode ser visualizada via Internet no endereço: http://www.lifesci.sussex.ac.uk/home/Neil_Crickmore/ (CRICKMORE et al., 2015).

As proteínas Cry são tóxicas para insetos das ordens Lepidoptera, Coleoptera, Hymenoptera, Diptera e nematoides (SOBERÓN et al., 2007) e as proteínas Cyt ativas para insetos da ordem Diptera (BRAVO et al., 2005).

Os cristais de Bt (Figura 1), ao serem ingeridos pelas larvas de insetos suscetíveis, são solubilizados no intestino médio que apresenta um $\mathrm{pH}$ em torno de 9,5, liberando uma ou mais proteínas (KNOWLES, 1994). As toxinas Cry ao serem ativadas pelas proteases do intestino se ligam a receptores específicos nas microvilosidades das células epiteliais do intestino médio (MONNERAT \& BRAVO, 2000; BRAVO et al., 2005), já as toxinas Cyt se interagem diretamente com os lipídeos da membrana (PROMDONKOY \& ELLAR, 2003), ambas formadoras de poro (PFT) (BRAVO et al., 2011).

Com a ocorrência da ligação destas toxinas aos receptores específicos e abertura ou formação dos poros na membrana intestinal das larvas inicia-se um desequilíbrio osmótico entre o meio intra e extracelular, ocasionando a perda da integridade da membrana (LIANG et al., 1995; RABINOVITCH et al., 2000).

Os sintomas apresentados pelas larvas dos insetos suscetíveis após ingerirem os cristais e esporos de B. thuringiensis são: perda de apetite e abandono do alimento, paralisia do intestino, vômito, diarréia, paralisia geral e por fim morte do inseto. (ARONSON et al., 1986). 


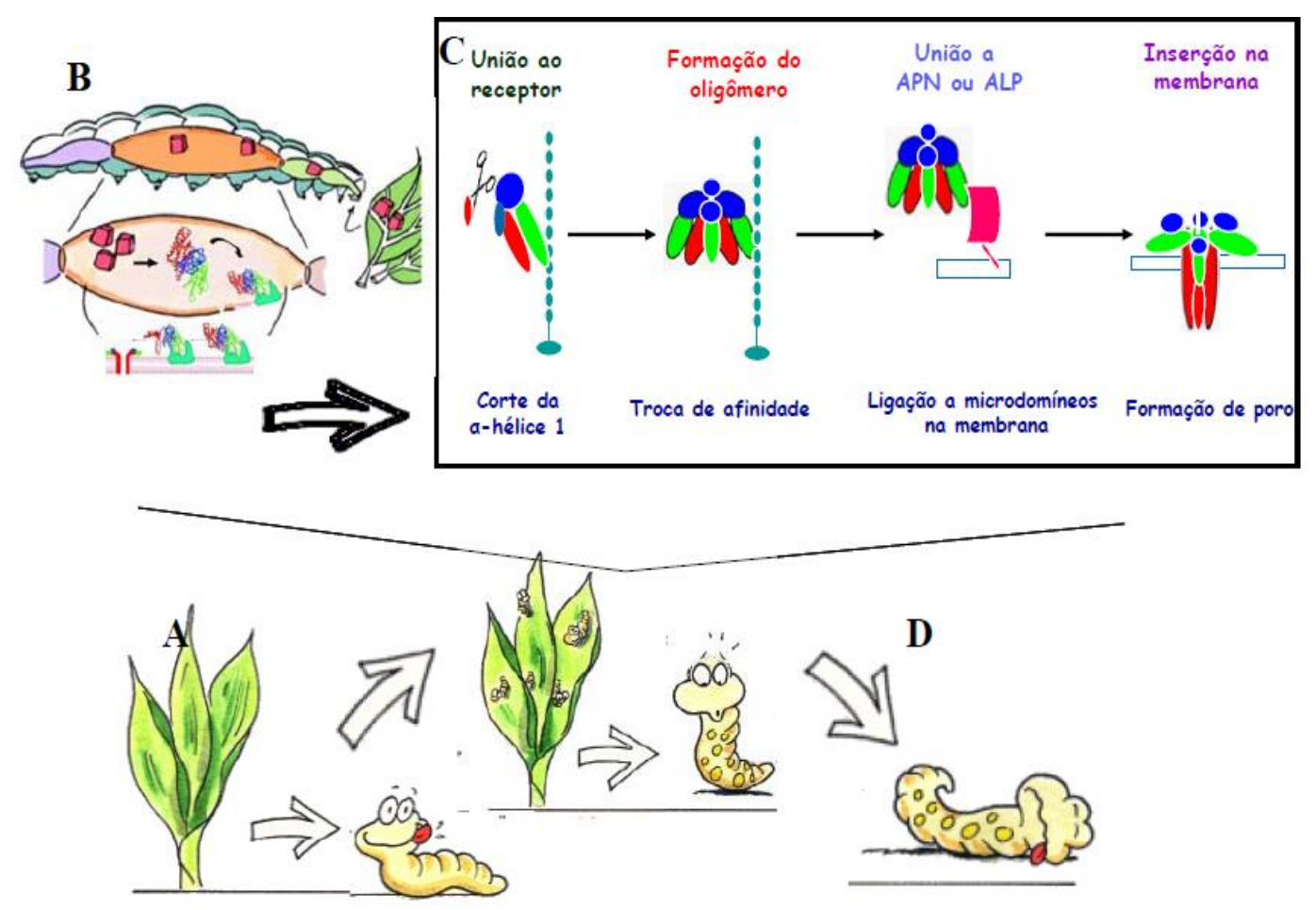

Figura 1 - Esquema do modo de ação de toxinas Cry para lepidópteros. A - O inseto ingere os cristais; B - no intestino médio da larva os cristais são solubilizados e ativados em proteínas que se ligam ao receptor; C - Esta ligação resulta na ativação de vias de sinalização intracelulares. Após se ligar ao receptor, há a inserção da toxina na membrana, formando poros e ativando vias de sinalização intracelular que podem ativar respostas apoptóticas e choque osmótico induzidos pela formação do poro; D - levando o inseto à morte (Adaptado de Bravo et al, 2007).

A aplicação de $B$. thuringiensis no controle de insetos pragas é uma ferramenta poderosa por não contaminar o meio ambiente, ser altamente específica devido à presença de receptores específicos no intestino médio dos insetos-alvo e pela ausência de interação dos receptores dos insetos benéficos e vertebrados (PIGOTT \& ELLAR 2007; BRAVO et al., 2011).

Além da sua utilização como inseticida biológico estão sendo realizados estudos para verificar o seu potencial como inoculante vegetal. B. thuringiensis como inoculante foi testado em alface (GOMES et al., 2003), soja (BAI et al., 2003), leguminosas (TANUJA et al., 2013), algodão (SANTANA, 2014) e amendoim (WANG et al, 2014) e os resultados obtidos apontaram o seu potencial como uma alternativa promissora na promoção de crescimento vegetal. 


\subsection{Bactérias promotoras de crescimento vegetal}

Rizobactérias promotoras de crescimento vegetal (PGPR - Plant growth-promoting rhizobacteria) são bactérias com capacidade de colonizar as raízes e que exercem efeitos benéficos no crescimento e desenvolvimento das plantas (CHOUDHARY \& JOHRI, 2009).

A utilização de PGPR permite melhor absorção de água e nutrientes pelas plantas e a consequente diminuição do uso de fertilizantes e pesticidas químicos proporcionando uma maior sustentabilidade do sistema de produção (CANDIDO et al., 2013).

Estirpes com atividade PGPR já relatados pertencem aos gêneros Agrobacterium, Arthrobacter, Azospirillum, Bacillus, Bradyrhizobium, Frankia, Pseudomonas, Rhizobium, Serratia, Thiobacillus (CHOUDHARY \& JOHRI, 2009), Mesorrhizobium (AHMAD et al., 2008), Azoarcus, Azotobacter, Clostridium, Enterobacter, Gluconacetobacter (HUREK \& REINHOLD-HUREK, 2003).

Porém já foram relatadas evidências de que a promoção de crescimento vegetal é maior quando induzido por bactérias endofiticas do que apenas por rizobactérias (TANUJA et al., 2013).

As bactérias endofíticas são aquelas que possuem capacidade de colonizar os tecidos internos das plantas (TANUJA et al., 2013), ou seja, conseguem atravessar o córtex da raiz e atingir o sistema vascular sendo encontrado no caule e nas folhas (PRAÇA et al., 2012; COMPANT et al., 2005).

As PGPRs podem estimular o crescimento de forma direta através da fixação de nitrogênio, produção de hormônio vegetal, solubilização de fósforo e produção de sideróforos (SZENTES et al., 2013) ou podem viver de forma endofítica apenas para se proteger de ambiente competitivo sem ganhar ou provocar nenhum dano (WELLINGTON \& BORGES, 2004).

Nos solos existem diversas populações de bactérias aeróbicas formadoras de endósporos que podem contribuir direta e indiretamente na produtividade das culturas, como exemplo Bacillus spp. (CHOUDHARY \& JOHRI, 2009).

A maioria tem a capacidade de se desenvolver de forma endofítica, além de ser um organismo do solo de vida livre como B. cereus, B. insolitus, B. megaterium, B. pumilus, Bacillus subtilis, P. polymyxa, (SHISHIDO et al., 1999) e B. thuringiensis (MONNERAT et al., 2003; PRAÇA et al., 2012) e também promoveram o crescimento vegetal (GOMES et al., 2003; TANUJA et al., 2013; WANG et al, 2014). 
Trabalhos realizados por Tanuja et al. (2013) e Praça et al. (2012) com diferentes estirpes de $B$. thuringiensis verificaram a capacidade destas de colonizarem o interior das raízes e migrarem endofiticamente para o caule e folhas das plantas.

Os mecanismos de promoção de crescimento vegetal pelas bactérias podem ser influenciados por diversos fatores abióticos e bióticos (BLOEMBERG \& LUTGTENBERG, 2001), mostrando a necessidade de estudos aprofundados sobre os mecanismos e dos seus efeitos benéficos nas condições de campo.

\subsection{Mecanismos de promoção de crescimento}

A promoção de crescimento vegetal por microrganismos é favorecida por mecanismos diretos como a fixação biológica de nitrogênio, produção de fitohormônios, solubilização de fosfato e disponibilização de outros nutrientes (STURZ et al., 2000; SZENTES et al., 2013) e/ou por mecanismos indiretos como o controle biológico de fitopatógenos e insetos (AZEVEDO et al., 2000; STURZ et al., 2000) pelo aumento da resistência a estresses bióticos e abióticos (BULGARELLI et al., 2013) e produção de sideróforos (SHARMA \& JOHRI, 2003).

Os mecanismos de promoção do crescimento vegetal, apresentados por estes microrganismos podem ser explorados em benefício de uma agricultura mais sustentável e de menor impacto ambiental (JAMES \& BALDANI, 2012). As bactérias que apresentam mais de uma característica para a promoção de crescimento são almejadas para uma possível aplicação em campo (VERMA et al., 2001).

Desta forma, a exploração e utilização de microrganismos eficientes na promoção do desenvolvimento vegetal podem auxiliar na sustentabilidade da atividade agrícola pela diminuição do uso de insumos derivados - direta ou indiretamente - do petróleo (DOBBELAERE et al., 2003; LUGTENBERG \& KAMILOVA, 2009).

O crescimento e desenvolvimento vegetal muitas vezes são respostas da produção de reguladores de crescimento produzidos por diferentes espécies de bactérias associadas aos vegetais (OLIVEIRA et al., 2014). 


\subsubsection{Produção de sideróforos}

O ferro é um nutriente essencial para inúmeros processos biológicos, como respiração e síntese de DNA e componente de proteínas envolvidas no processo de transferência de elétrons (PIERRE \& FONTECAVE, 1999).

É um dos minerais mais abundantes na Terra, porém ele está relativamente indisponível no solo para a assimilação direta pelos microrganismos. Para superar esse problema, os microrganismos do solo secretam os sideróforos (DOBBELAERE et al., 2003).

Sideróforos bacterianos são moléculas de baixo peso molecular que são produzidas também por PGPRs e que se ligam ao ferro com alta afinidade (GRAY \& SMITH, 2005; SHARMA \& JOHRI, 2003). Podem ser produzidos por bactérias dois tipos de sideróforos: o hidroxamato e o catecol (NEILANDS \& NAKAMURA, 1991).

O complexo ferro-sideróforo não é prejudicial para as plantas, sendo que algumas conseguem capturar esse complexo para dentro de suas células, onde o ferro é liberado e disponibilizado para os processos biológicos (CROWLEY et al., 1988), além de inibir o crescimento de microrganismos patogênicos para as plantas (SHARMA \& JOHRI, 2003)

O sideróforo tem a função de transportar o ferro através da membrana celular. A entrada do ferro no citoplasma acontece depois que o ferro é reduzido e/ou desmembrado do seu ligante, podendo o sideróforo ser reciclado para iniciar novamente o processo (NEILANDS, 1995).

\subsubsection{Produção de fitohormônios}

Dos fitohormônios produzidos por bactérias a auxina é a mais estudada, sendo que a capacidade de síntese deste fitohormônio tem distribuição ampla entre bactérias associativas, e acredita-se que $80 \%$ das bactérias da rizosfera produzem auxinas (PATTEN \& GLICK , 1996).

A auxina é o hormônio vegetal produzido em maior quantidade, sendo o seu composto mais estudado o ácido indolacético (AIA) (PATTEN \& GLICK, 1996). A auxina tem como principais funções promover o alongamento celular, divisão, diferenciação celular e de tecidos e a formação radicular, além de aumentar a resistência a fatores de estresse (TSAVKELOVA et al., 2006; TAIZ \& ZEIGER, 2006). O triptofano tem sido identificado como a principal molécula precursora da biossíntese de AIA em bactérias (TSAVKELOVA et al., 2006). 
A biossíntese de AIA por L-triptofano pode ocorrer por duas vias distintas, uma pela enzima chamada ipdC ou IpyA (índole-3pyruvate descarboxylase) (LEBUHN \& HARTMANN, 1993) e outra pela enzima IAM (indol-3-acetaldeido) (BROEK et al., 1999).

\subsubsection{Fixação de nitrogênio}

O nitrogênio é um dos elementos mais importantes para o desenvolvimento das plantas (GUIMARÃES et al., 2003), por ser constituinte de diversas moléculas como ácidos nucléicos, aminoácidos, bases nitrogenadas, clorofila e outros (FERREIRA, 2008; MOREIRA \& SIQUEIRA, 2006).

É o elemento mais abundante na atmosfera sendo encontrado na forma de $\mathrm{N}_{2}$, porém essa forma química é inacessível para os seres eucariotos e para a maioria dos procariotos. Alguns microrganismos possuem uma enzima chamada nitrogenase, que permite a estes transformarem o $\mathrm{N}_{2}$ em fontes assimiláveis pelos vegetais e outros seres vivos, sendo denominados de fixadores de nitrogênio ou diazotróficos (MOREIRA \& SIQUEIRA, 2006).

A utilização de microrganismos que fixam nitrogênio do ar e melhoram o crescimento e desenvolvimento vegetal, contribuem para a diminuição do uso de adubos nitrogenados e consequentemente a contaminação do meio ambiente (BARRAQUIO, 1997; CHOUDHURY \& KENNEDY, 2004; GRAY \& SMITH, 2005).

O uso extensivo de fertilizantes nitrogenados na agricultura gera diversos problemas, sendo o ambiental provocado devido grande parte dos fertilizantes adicionados ao solo serem consumido por bactérias (que oxidam o nitrogênio, liberando óxido nitroso e óxido nítrico na atmosfera) ou lixiviado pelas águas até o lençol freático, causando a eutrofização de rios e lagos (LEWIS et al., 1984).

As espécies fixadoras de nitrogênio são na sua maioria de vida livre e ocorrem nos diferentes tipos de solos, rizosferas, água doce ou salgada, em associações ou não com fungos e outros animais. Podem ainda viver endofiticamente nas plantas colonizando os tecidos internos (CRAWFORD et al, 2000; MOREIRA \& SIQUEIRA, 2006).

No final dos anos 90 foram relatados como microrganismos endofiticos diazotróficos, os pertencentes aos gêneros Agrobacterium, Azospirillum, Bacillus, Pseudomonas e Rhizobium (CHANWAY, 1998). 


\subsubsection{Solubilização de fosfato}

O fósforo é o nutriente mais abundante nos solos, porém é o maior limitante do crescimento vegetal, por ser essencial ao desenvolvimento das plantas. Esse elemento é o componente principal de nucleotídeos, e esta relacionado com o armazenamento e transferência de energia sob forma de ATP (NOVAIS et al., 2007; FORNASIERI FILHO, 1992).

Microrganismos presente no solo são capazes de solubilizar fosfato mineral insolúvel pela produção de vários ácidos orgânicos que acidificam o solo, liberando íons ortofosfato solúveis, que podem ser captados pelas plantas (JONES, 1998).

A solubilização de compostos orgânicos fosfatados por microrganismos só acontece quando ocorre a liberação da enzima fosfatase (GYANESHWAR et al., 2002; GARCIA et al., 1992) ou fosfohidrolases, classificadas em ácidas ou alcalinas de acordo com o pH ótimo de atividade. Estas enzimas podem ser secretadas fora da membrana plasmática, ou permanecerem retidas na membrana como proteínas solúveis (RODRÍGUEZ \& FRAGA, 1999).

Entre os gêneros relatados com a capacidade de solubilizar fosfato inorgânico estão Pseudomonas, Bacillus, Rhizobium, Burkholderia, Achromobacter, Agrobacterium, Microccocus, Flavobacterium e Erwinia (RODRÍGUEZ \& FRAGA, 1999).

Considerando que a disponibilidade de $\mathrm{P}$ é uma etapa limitante para a nutrição da planta, a habilidade em solubilizar fosfato inorgânico por bactérias associativas representa um grande potencial para a promoção do crescimento vegetal (OLIVEIRA et al., 2014). 


\section{OBJETIVOS}

\subsection{Objetivo Geral}

Selecionar estirpes de Bacillus thuringiensis com toxicidade para Helicoverpa armigera e potencial para promoção de crescimento vegetal.

\subsection{Objetivos Específicos}

- Selecionar estirpes de B. thuringiensis tóxicas à H. armigera;

- Caracterizar as estirpes de $B$. thuringiensis tóxicas à $H$. armigera por métodos bioquímicos e moleculares;

- Identificar e selecionar estirpes de B. thuringiensis produtoras de auxinas, sideróforos, solubilizadoras de fosfato inorgânico e fixadoras de nitrogênio de forma assimbiótica in vitro;

- Caracterizar estirpes de B. thuringiensis por método molecular para os genes de promoção de crescimento. 


\section{REFERÊNCIAS}

AHMAD, F.; AHMAD, I.; KHAN, M.S. Screening of free-living rhizospheric bacteria for their multiple plant growth promoting activities. Microbiological Research, v. 163, p. 173$181,2008$.

ARONSON, A.I.; BECKMAN, W.; DUNN, P. Bacillus thuringiensis and related insect pathogens. Microbiology Rewiew, v. 50, p. 1-24, 1986.

ÁVILA, C.J.; VIVIAN, L.M.; TOMQUEISKI, G. V. Ocorrência, aspectos biológicos, danos e estratégias de manejo de Helicoverpa armigera (Hübner) (Lepidoptera: Noctuidae) nos sistemas de produção agrícolas. Dourados: Embrapa Agropecuária Oeste,p. 1-12, 2013 (Circular técnica n 23).

AVILlA， C.; VARGAS-OSUNA， E.; GONZÁLEZ-CABRERA， J.; FERRÉ, J.; GONZÁLEZ-ZAMORA, J.E. Toxicity of several $\delta$-endotoxins of Bacillus thuringiensis against Helicoverpa armigera (Lepidoptera: Noctuidae) from Spain. Journal of Invertebrate Pathology, v. 90, p. 51-54, 2005.

AZEVEDO, J.L.; ARAÚJO, W.L.; MACCHERONI-JR, W. Importância dos microrganismos endofiticos no controle de insetos. In: MELO, I.S.; AZEVEDO, J.L. (Ed.) Controle Biológico. Jaguariúna: Embrapa Meio Ambiente, cap. 3, p. 57-93, 2000.

BAI, Y.X., ZHOU, X., SMITH, D.L. Enhanced Soybean plant growth resulting from coinoculation of Bacillus strains with Bradyrhizobium japonicum. Crop Science, v. 43, p. 1774-1781, 2003.

BARJAC, H.; BONNEFOI, A. Essai de classification biochimique et seroloqique de 24 souches de Bacillus du type Bacillus thuringiensis. Enthomophaga, v.7, p. 5-31, 1962.

BARRAQUIO, W.L.; REVILLA L.; LADHA, J.K. Isolation of endophytic diazotrophic bacteria from wetland rice. Plant and Soil, v. 194, p.15-24, 1997.

BLOEMBERG, G.V.; LUGTENBERG, B.J.J. Molecular basis of plant growth promotion and biocontrol by rhizobacteria. Current Opinion in Plant Biology, v.4, p. 343-350, 2001. 
BRAVO, A.; GILL, S. S.; SOBERÓN, M. Bacillus thuringiensis mechanisms and use. In: GILBERT, L. I., LATROU, K., GILL, S. S. (Ed.). Comprehensive Molecular Insect Science. Amsterdam: Elsevier BV. p. 175-206, 2005.

BRAVO, A.; GILL, S.S.; SOBERÓN, M. Mode of action of Bacillus thuringiensis Cry and Cyt toxins and their potential for insect control. Toxicon, v.49, p. 423-435, 2007.

BRAVO, A.; LIKITVIVATANAVONG, S.; GILL, S.S.; SOBERÓN, M. Bacillus thuringiensis: a story of a successful bioinsecticide. Insect Biochem Mol Biol, v. 41, p. 423431, 2011.

BROEK, A.V. Auxins upregulate expression of the indole-3- Pyruvate dercarboxylase gene in Azospirillum brasilense. Journal of Bacteriology, Washington, v. 181, p. 1338-1342, 1999.

BUENO, R.C.O.F.; YAMAMOTO, P. T.; CARVALHO, M.M. BUENO, N. M. Occurence of Helicoverpa armigera (HÜBNER, 1808) on citrus in the state of São Paulo, Brazil. Rev. Bras. Frutic., v. 36, n. 2, p. 520-523, 2014.

BULGARELLI, D.; SCHLAEPPI, K.; SPAEPEN, S.; VAN THEMAAT, E. V. L.; SCHULZE-LEFERT, P. Structure and functions of the bacterial microbiota of plants. Annual Review of Plant Biology, v. 64, p. 807-838, 2013.

CANDIDO, V.; CAMPANELLI, G.; D’ADDABBO, T.; CASTRONUOVO, D.; RENCO, M.; CAMELE, I. Growth and yield promoting effect of artificial mycorrhization combined with different fertiliser rates on field-grown tomato. Italian Journal of Agronomy, p.8-22, 2013.

CHANWAY, C.P. Bacterial endophytes: ecological and practical implications. Sydowia, v.50, p. 149-170, 1998.

CHOUDHARY, D.K.; JOHRI, B.N. Interactions of Bacillus spp. and plants - With special reference to induced systemic resistance (ISR). Microbiological Research, v.164, p.493-513, 2009.

CHOUDHURY, A.T.M.A.; KENNEDY, I.R. Prospects and potentials for systems of biological nitrogen fixation in sustainable rice production, Biology and Fertility of Soils, v. 39, p. 219-227, 2004. 
COMPANT, S.; REITER, B.; SESSITSCH, A.; NOWAK, J.; CLEMENT, C.; AIT BARKA, E. Endophytic colonization of Vitis vinifera L. by a plant growth promoting bacterium, Burkholderia sp. strain PsJN. Applied and Environmental Microbiology, v.71, p.16851693, 2005.

CRAWFORD, N.M., Nitrogen and sulfur. In: BUCHANAN, B.B; GRUISSEM, W.; JONES, R.L. Biochemestry \& Molecular Biology of plants. Rockville: American Society of plant physilogists, p. 786-849, 2000.

CRICKMORE, N.; ZEIGLER, D. R.; SCHNEPF, E.; VAN RIE, J.; LERECLUS, D.; BAUM, J.; BRAVO, A.; DEAN, D. H. Bacillus thuringiensis toxin nomenclature. Disponível em: http://www.biols.susx.ac.uk/Home/Neil_Crickmore/Bt/. Acesso em: 30 janeiro 2015.

CROWLEY, D.E.; REID, C.P.P.; SZANISZLO, P.J. Utilization of microbial siderophores in iron acquisition by oat. Plant Phys, v.87, p. 680-685, 1988.

CUNNINGHAM, J.P.; ZALUCKI, M.P.; WEST, S.A. Learning in Helicoverpa armigera (Lepidoptera: Noctuidae): a new look at the behaviour and control of a polyphagous pest. Bulletin of Entomological Research, v. 89, n. 3, p. 201-207, 1999.

CZEPAK, C.; ALBERNAZ, K.C.; VIVAN, L.M.; GUIMARÃES, H.O.; CARVALHAIS, T. Primeiro registro de ocorrência de Helicoverpa armigera (Hübner) (Lepidoptera: Noctuidae) no Brasil. Pesquisa Agropecuária Tropical, v.43, p.110-113, 2013.

DOBBELAERE, S.; VANDERLEYDEN, J.; OKON, Y. Plant growth-promoting effects of diazotrophs in the rhizosphere. Crit Rev Plant Sci, v. 22, p. 107-149, 2003.

ESTRUCH, J.J.; WARREN, G.W.; MULLINS, M.A.; NYE, G.J.; CRAIG, J.A.; KOZIEL, M.G. Vip3A, a novel Bacillus thuringiensis vegetative insecticidal protein with a wide spectrum of activities against lepidopteran insects. Proceedings of the National Academy of Sciences of the United States of America, v.93, p.5389-5394, 1996.

FERREIRA, J.S. Qualidade de inoculante, inoculação e reinoculação de Herbaspirillum seropedicae em duas variedades de arroz irrigado. Tese de Doutorado. Universidade Federal Rural do Rio de Janeiro, Seropédica, 2008. 
FIGUEIREDO, M.V.B.; SELDIN, L.; ARAUJO, F.F.; MARIANO, R.L.R. Plant Growth Promoting Rhizobacteria: Fundamentals and Applications. In: Plant growth and health promoting bacteria. Berlin: Springer,v.18, p.21-43, 2010.

FITT, G. P. The ecology of Heliothis species in relation to agroecosystems. Annual Review of Entomology, Palo Alto, v. 34, n. 1, p. 17-52, 1989.

FORNASIERI FILHO, D. A cultura do milho. Jaboticabal: FUNEP, 1992.

GARCIA, C.; FERNANDEZ, T.; COSTA, F. CERRANTI, B.; MASCIANDARO, G. Kinetics of phosphatase activity in organic wastes. Soil Biol Biochem. v. 25, p. 361-365, 1992.

GOMES, A.M.A.; MARIANO, R.L.R.; SILVEIRA, E.B.; MESQUITA, J.C.P. Isolamento, seleção de bactérias e efeito da utilização de Bacillus spp. na produção de mudas orgânicas de alface. Horticultura Brasileira, Brasília, v. 21, n. 4, p. 699-703, outubro-dezembro 2003.

GRAY, E.J.; SMITH, D.L. Intracellular and extracelular PGPR:commonalities and distinctions in the plant-bacterium signaling processes. Soil Biology And Biochemistry, v. 37, p. 395-412, 2005.

GUIMARÃES, S.L.; BALDANI, J.I.; BALDANI, V.L.D. Efeito da inoculação de bactérias diazotróficas endofíticas em arroz de sequeiro. Agronomia, v.37, p.25-30, 2003.

GUO, Y.Y. Progress in the researches on migrationregularity of Helicoverpa armigera and relationships between the pest and its host plants. Acta Entomologica Sinica, v. 40, n. 1, p. $1-6,1997$.

GYANESHWAR, P.; KUMAR, G. N.; PAREKH, L. J.; POOLE, P. S.Role of soil microorganisms in improving P nutrition of plants. Plant and Soil, v. 245, p. 83-93, 2002.

HANSEN, B.M., SALAMITOU, S. Virulence of Bacillus thuringiensis. In: Entomopathogenic Bacteria: From Laboratory to Field Application (Charles, J. et al., eds), p. 41-64, Kluwer Academic Publishers, 2000.

HUREK, T.; REINHOLD-HUREK, B. Azoarcus spp. strain BH72 as a model for nitrogen fixing grass endophytes. Journal Biotechnology, p.106:169, 2003. 
JAMES, E.K.; BALDANI, J.I. The role of biological nitrogen fixation by non-legumes in the sustainable production of food and biofuels. Plant and Soil, v. 356, p. 1-3, 2012.

JONES, D.L. Organic acids in the rhizosphere - a critical review. Plant Soil, v. 205, p. 25-44, 1998.

KNOWLES, B. Mechanism of action of Bacillus thuringiensis insecticidal $\delta$-endotoxins. Adv. Insect. Physiol, v.24, p. 275-308, 1994.

LEBUHN, M.; HARTMANN, A. Method for the determination of indole-3-acetic acid and related compounds of L-tryptohan catabolism in soils. Journal of Chromatography, v. 629, p. 255-266, 1993.

LEWIS, W.M.; SAUNDERS, J.F.; CRUMPAKER, D.W.; BRENDECKE， C.M. Eutrophication and land use, Lake Dillon, Colorado. Ecological Studies, v.46, 202 p., 1984.

LIANG, Y., PATEL, S.S.; DEAN, D.H. Irreversible binding kinectics of Bacillus thuringiensis CryIA-endotoxins to Gypsy moth brush border membrane vesicles is directly correlated to toxicity. J. Biol. Chem, 1995.

LUGTENBERG, B.; KAMILOVA, F. Plant-growth-promoting rhizobacteria. Annual Review of Microbiology, v. 63, p. 541-556, 2009.

MONNERAT, R.G.; BRAVO, A. Proteínas bioinseticidas produzidas pela bactéria Bacillus thuringiensis: modo de ação e resistência. In: Controle Biológico, eds. MELO, I. S.; AZEVEDO, J.L., Jaguariúna: Embrapa Meio Ambiente. v. 3, p. 163-200, 2000.

MONNERAT, R.G.; SANTOS, R.; BARROS, P.; BATISTA, A.; BERRY, C. Isolamento e caracterização de estirpes de Bacillus thuringiensis endofíticas de algodão, Brasília: Embrapa Recursos Genéticos e Biotecnologia, 2003, 4p. (Embrapa Recursos Genéticos e Biotecnologia, Comunicado técnico, 98).

MOREIRA, F.M.S.; SIQUEIRA, J.O. Fixaçãoo biológica de nitrogênio atmosférico. In: MOREIRA, F.M.S.; SIQUEIRA, J.O Microbiologia e Bioquímica do Solo. Lavras: Editora UFLA, 2006. p.449-542.

NASERI, B.; FATHIPOUR, Y.; MOHARRAMIPOUR, S.; HOSSEININAVEH, V.; GATEHOUSE, A. M. Digestive proteolytic and amylolytic activities of Helicoverpa 
armigera in response to feeding on different soybean cultivars. Pest Management Science, v. 66, n. 12, p. 1.316-1.323, 2010.

NEILANDS, J.B. Siderophores: Structure and Function of Microbial Iron Transport Compounds. The Journal of Biological Chemistry, v. 270, n. 45, 1995.

NEILANDS, J.B.; NAKAMURA, K. Detection, determination, isolation, characterization and regulation of microbial iron chelates. In: WINKELMANN, G. (Ed.). CRC handbook of microbial iron chelates. Florida: CRC Press, 1991. p.1-14.

NOVAIS, R.F.; ALVAREZ, V.H.; BARROS, N.F.; FONTES, R.L.F.; CANTARUTTI, R.B.; NEVES, J.C.L. Fertilidade o Solo. 1 ${ }^{\text {a }}$. Ed. Viçosa: Sociedade Brasileira de Ciência do Solo, 2007. 1017p.

OLIVEIRA, A.L.M.; COSTA, K.R.; FERREIRA, D.C.; MILANI, K.M.L.; SANTOS, O.J.A.P.; SILVA, M.B.; ZULUANGA, Y.A.Biodiversity of soil bacteria and its applications for a sustainable agriculture. Biochemistry and Biotechnology Reports, v.3, n.1, p. 56-77, 2014.

PATTEN, C.L.; GLICK, B.R. Bacterial biosynthesis of indole-3-acetic acid. Canadian Jounal of Microbiology, v.42, p.207-220, 1996.

PEDGLEY, D. E. Windborne migration of Heliothis armigera (Hübner) (Lepidoptera: Noctuidae) to the British Isles. Entomologist's Gazette, v. 36, n. 1,p. 15-20, 1985.

PIERRE, J.L.; FONTECAVE, M. Iron and activated oxygen species in biology: the basic chemistry. Biometals, v.12, p. 195-199, 1999.

PIGOTT, C.R.; ELLAR, D.J. Role of receptors in Bacillus thuringiensis crystal toxin activity. Microbiol Mol Biol Ver, v. 71, p.255-281, 2007.

PRAÇA, L.B.; GOMES, A.C.M.M.; CABRAL, G. MARTINS, E.S.; SUJII, E.R.; MONNERAT, R.G. Endophytic colonization by Brazilian strains of Bacillus thuringiensis on cabbage seedlings grown in vitro. Bt Research, v.3, n.3, p.11-19, 2012.

PROMDONKOY, B., ELLAR, D.J. Investigation of the pore forming mechanism of a Cytolitic d-endotoxin from Bacillus thuringiensis. Biochem. J. v. 374, p.255-259, 2003. 
RABINOVITCH, L.; SILVA, C.M.B.; ALVES, R.S. de A. Controle biológico de vetores de doenças tropicais utilizando Bacillus entomopatogênicos. In: Controle Biológico, Eds. MELO, I.S.; AZEVEDO, J.L. Jaguariúna, SP, Embrapa Meio Ambiente, v.2, p. 17-90, 2000.

RODRÍGUEZ, H.; FRAGA, R. Phosphate solubilizing bactéria and their role in plant growth promotion. Biotechnology Advances, v.17, p.319-339, 1999.

SAMPURNA, S.; MAITI, M. K. Molecular characterization of a novel vegetative insecticidal protein from Bacillus thuringiensis effective against sap-sucking insect pest. Journal of Microbiology and Biotechnology, v. 21, n. 9, p. 937-946, 2011.

SANTANA, F.S.C. Bacillus thuringiensis como endofíticos em algodão: avaliação na promoção de crescimento e controle de Spodoptera frugiperda. Dissertação de Mestrado, Universidade de Brasília, Brasília, 2014.

SHARMA, A.; JOHRI, B.N. Growth promoting influence of siderophore-producing Pseudomonas strains GRP3A and PRS9 in maize (Zea mays L.) under iron limiting conditions. Microbiological Research, v.158, p.243-248, 2003.

SHISHIDO, M.; BREUIL, C.; CHANWAY, C.P. Endophytic colonization of spruce by plant growth-promoting rhyzobacteria. FEMS Mictrobiology Ecology, v.29, p.191-196, 1999.

SOBERÓN, M.; FERNANDEZ, L.E.; PEREZ, C.; GILL, S.S.; BRAVO, A. Mode of action of mosquitocidal Bacillus thuringiensis toxins. Toxicon. v. 49, p. 597-600, 2007.

SPECHT, A.; SOSA-GOMEZ, D.R.; PAULA-MORAES, S.V.; YANO, S.A.C. Identificação morfológica e molecular de Helicoverpa armigera (Lepidoptera: Noctuidae) e ampliação de seu registro de ocorrência no Brasil. Pesquisa Agropecuária Brasileira, Brasília, v.48, n.6, p.689-692, 2013.

SRINIVASAN, R.; SU, F.; HUANG, C. Oviposition dynamics and larval development of Helicoverpa armigera on a highly preferred unusitable host plant, Solanum viarum. Entomologia Experimentalis et applicata, v. 147, p. 217-224, 2013.

SRIVASTAVA, C. P.; NITIN, J.; TRIVEDI, T.P. Forecasting of Helicoverpa armigera populations and impact of climate change. Indian Journal of Agricultural Sciences, v. 80, n.1, p. 3-10, 2010. 
STURZ, A.V.; CHRISTIE, B.R; NOWAK, J. Bacterial endophytes: potential role in developing sustainable systems of crop production. Critical Reviews in Plant Sciences. v. 19. p.1-30, 2000.

SZENTES, S.; RADU, G.; LASLO, É.; LÁNYI, S.; MARA, G. Selection and evaluation of potential biocontrol rhizobacteria from a raised bog environment. Crop Protection, v.52, p.116-124, 2013.

TAIZ, L.; ZEIGER, E. Fisiologia vegetal. 3a Ed. Artmed. Porto Alegre, 2006.

TANUJA, R.; BISHT, S.C.; MISHRA, P.K. Ascending migration of endophytic Bacillus thuringiensis and assessment of benefits to different legumes of N.W. Himalayas. European Journal of Soil Biology, v.56, p.56-64, 2013.

TSAVKELOVA, E. A.; KLIMOVA, S. YU.; CHERDYNTSEVA, T. A.; NETRUSOV A. I. Microbial producers of plant growth stimulators and their practical use: A Review. Applied Biochemistry and Microbiology, v.42, n.2, p. 117-126, 2006.

VASSAL, J.M.; BREVAULT, T.; ACHALEKE, J.; MENOZZI, P. Genetic structure of the polyphagous pest Helicoverpa armigera (Lepidoptera: Noctuidae) across the sub- Saharan cotton belt. Commun. Agric. Appl. Biol. Sci. v.73, p.433-437, 2008.

VERMA, S.C.; LADHA, J.K.; TRIPATHI, A.K. Evaluation of plant growth promoting and colonization ability of endophytic diazotrophs from deep qater rice. Journal of Biotechnology, v. 91, p. 127-141, 2001.

WANG, N.C.; LI, Z.H. Studies on the biology of cotton bollworn Heliothis armigera (Hübner) and H. punctigera Wallengren (Lepidoptera: Noctuidae) in Australia: what do we know? Australian Journal of Zoology, Melbourne, v.34, n.6, p.779-814, 1986.

WANG. T.; LIU, M.; LI H. f Acta Agriculturae Scandinavica, Section B - Soil \& Plant Science. v. 64, 2014

WARREN, G. W. Vegetative insecticidal proteins: novel proteins for control of corn pests, p. 109-121. In: CAROZZI, N.; KOZIEL, M., Advances in insect control: the role of transgenic plants. Taylor and Francis, 1997. 
WELLINGTON, B.; BORGES, M.T. Delivery methods for endophytic bacteria into maize, Biocontrol, v.49, p.315-322, 2004.

YU, C. G.; MULlinS, M. A.; WARREN, G. W.; KOZIEL, M. G.; ESTRUCH, J. J. The Bacillus thuringienses vegetative insecticidal protein Vip3A lyses midgut ephitelium cells of susceptible insects. Applied and Environmental Microbiology, v. 63, n. 2, p. 532-536, 1997. 


\section{CAPÍTULO ÚNICO}

SELEÇÃO DE ESTIRPES DE Bacillus thuringiensis TÓXICAS À Helicoverpa armigera E PROMOTORAS DE CRESCIMENTO VEGETAL 


\section{RESUMO}

O estudo objetivou selecionar 100 estirpes de Bacillus thuringiensis com toxicidade para Helicoverpa armigera e potencial para promoção de crescimento vegetal. Das estirpes avaliadas 23 apresentaram $100 \%$ de mortalidade para $H$. armigera, sendo quinze pertencentes às subsp. kurstaki (S607, S845, S1258, S1264, S1450-HD1, S1905, S2122, S2124), aizawai (S616, S1295), tolworthi (S1304), fokuokaensis (S608), sotto (S615), morrisoni (S1301), thuringiensis (S1269) e oito estirpes sem subespécie identificadas. As estirpes apresentam perfil proteíco de 130 e $65 \mathrm{kDa}$, sendo que algumas apresentaram apenas uma das proteínas e fragmentos de DNA de tamanho esperado para a detecção dos genes cryl e cry2. Na detecção da capacidade de promoção de crescimento in vitro, nenhuma estirpe apresentou a capacidade de produção de sideróforos, solubilização de fosfatos e fixação biológica de nitrogênio. Na produção de AIA todas as estirpes foram positivas e a quantidade variou de $1,17 \mu \mathrm{g} \mathrm{mL}^{-1}$ (estirpe S93) a 7,44 $\mathrm{g} \mathrm{mL}^{-1}$ (estirpe S1983). Das 100 estirpes analisadas 45 apresentaram amplicons esperados para todos os genes avaliados, sendo que 71 estirpes apresentaram amplicons de tamanhos esperados para o gene fosfatase ácida, 57 foram positivos para os genes sideróforos. Os genes envolvidos nas rotas de biossíntese do hormônio AIA se mostraram mais frequentes em estirpes de $\mathrm{Bt}$, sendo que das estirpes analisadas 91 foram positivos para a presença do gene ipdC, 97 para o genes iaml e 93 para o gene iam2. B. thuringiensis pode ser utilizado no controle de $H$. armigera e possui potencial como inoculante para a promoção de crescimento vegetal, abrindo novas perspectivas para o uso agronômico.

Palavras-chave: controle biológico, metabólitos secundários, diversidade genética. 


\begin{abstract}
This work to select 100 strain of Bacillus thuringiensis wich toxicity to Helicoverpa armigera and potential for plant growth promotion. 23 strains showed $100 \%$ the mortality against $H$. armigera, of which fifteen belonged to subsp. kurstaki (S607, S845, S1258, S1264, S1450HD1, S1905, S2122, S2124), aizawai (S616, S1295), tolworthi (S1304), fokuokaensis (S608), sotto (S615), morrisoni (S1301), thuringiensis (S1269) and eight without serotype. Some strains exhibited the profile of 130 and $65 \mathrm{kDa}$, other showed just one of the proteins and the amplicons with the expected size of cryl and cry 2 gene. In vitro detection of growth promotion capability, showed that no strain had the siderophore production capability, phosphate solubiliation and biological fixation of nitrogen. All strains tested were capable of produce IAA, and the amount varied from $1,17 \mu \mathrm{g} \mathrm{mL}^{-1}$ (S93 strain) to 7,44 $\mu \mathrm{g} \mathrm{mL}^{-1}$ (1983 strain). 45 of the 100 analyzed strains showed the expected amplicons for all the studied genes, 71 strains showed the expected amplicon size for the acid phosphatase gene, 57 were positive for siderophore gene. The genes involved in the biosynthesis of IAA hormone were more frequents in Bt strains, 91 strains were positive for the presence of ipdC gene, 97 were positive for iam1 gene, and 93 for iam2 gene. B thuringiensis can be used in biological control against $H$. armigera and has a great potencial to promote plant growth, creating new perspectives for agronomic use.
\end{abstract}

Keywords: Biological control, secondary metabolite, genetic diversity. 


\section{INTRODUÇÃO}

O Brasil destaca-se no cenário mundial pela importância da sua produção agrícola, que é baseada no modelo convencional, que emprega de forma intensiva, fertilizantes químicos e agrotóxicos, tornando o País um dos maiores consumidores mundiais.

Os insumos utilizados na agricultura brasileira são na sua maior parte importados, já que a indústria brasileira não acompanhou o crescimento agrícola. Com isso, os produtores ficam reféns da disponibilidade e dos preços praticados pelo mercado internacional, o que provoca uma insegurança econômica e aumento dos custos de produção.

As condições ambientais brasileiras juntamente com a melhoria da fertilidade dos solos, a irrigação e o desenvolvimento de variedades adaptadas, permitiram a produção em várias regiões e épocas do ano. Tal fato, entretanto possibilita aumento populacional de algumas espécies de insetos que assumem o papel de praga, o que é ainda mais acentuado por extensas áreas agrícolas com monocultivo.

Na safra 2012/2013, mas provavelmente com introdução anterior a essa data, foi registrada a ocorrência de Helicoverpa armigera em cultivos de algodão, soja, milho, tomate e citros, até então considerada uma praga quarentenária A1, mas que obteve o status de praga e causou perdas econômicas significativas em vários estados brasileiros, principalmente no oeste da Bahia. Espécie polífaga, tem preferência em se alimentar das estruturas reprodutivas das plantas, como flores, inflorescências, frutos e vagens. Todavia, também ataca brotos, folhas e caules.

O MAPA liberou em 2013, em caráter emergencial, na tentativa de reduzir os danos ocasionados pela $H$. armigera, diversos produtos fitossanitários, dentre eles o benzoato de emamectina, inseticida de classe toxicológica I, produto extremamente tóxico e altamente perigoso ao meio ambiente.

Porém, o uso intensivo e indiscriminado desses produtos impacta na elevação do custo de produção e podem degradar os recursos naturais, contaminar o solo, água, alimentos, flora e fauna, provocando desequilíbrios biológicos e ecológicos.

O desenvolvimento de novas abordagens, que venham a auxiliar a agricultura brasileira, mas que não impliquem na geração de mais dependência externa ou aumentem os já severos impactos ambientais pode ser realizada com a ampliação da oferta de insumos biológicos, como a tecnologia de inoculação com rizóbios na soja, rizobactérias promotoras de crescimento vegetal (PGPR) e pelo uso de microrganismos no controle de insetos-pragas. 
Neste contexto, o emprego de Bacillus thuringiensis, uma bactéria entomopatogênica a insetos de várias ordens e que também tem a capacidade de estimular o crescimento de plantas como já demonstrado em alface (GOMES et al., 2014), leguminosas (TANUJA et al., 2003), amendoim (WANG et al., 2014) e ainda como inseticida sistêmico (PRAÇA et al., 2012) pode vir a ser uma alternativa interessante.

O presente trabalho tem por objetivo selecionar estirpes de B. thuringiensis, que além de serem tóxicas à $H$. armigera, apresentem potencial para promover o crescimento vegetal. 


\section{MATERIAL E MÉTODOS}

A Embrapa Recursos Genéticos e Biotecnologia possui desde 1987 uma Coleção de Bactérias de Invertebrados composta por 2583 estirpes de Bacillus spp.

Para a realização deste trabalho foram selecionadas 100 estirpes de B. thuringiensis. Algumas das estirpes escolhidas já possuiam subespécie identificada e apresentarem toxicidade a insetos da ordem Lepidoptera e outras foram avaliadas pela primeira vez.

A fim de avaliar a toxicidade destas estirpes de B. thuringiensis para lagartas de $H$. armigera, bioensaios seletivos foram realizados. As estirpes que apresentaram 100\% mortalidade a este inseto foram caracterizadas molecular e bioquimicamente. As mesmas estirpes foram avaliadas também quanto à capacidade de produção de metabólitos secundários in vitro relacionados à promoção de crescimento vegetal e caracterizadas quanto à presença dos genes.

Os experimentos foram conduzidos no Laboratório de Bactérias Entomopatogênicas da Embrapa Recursos Genéticos e Biotecnologia - Brasília-DF.

\subsection{Determinação da toxicidade de $\boldsymbol{B}$. thuringiensis à $\boldsymbol{H}$. armigera}

\subsubsection{Criação massal de Helicoverpa armigera}

A criação massal de $H$. armigera foi estabelecida no Laboratório de Cultura de Plantas e Insetos da Embrapa Recursos Genéticos e Biotecnologia. Para isso, os ovos foram gentilmente cedidos pela Embrapa Hortaliças.

Após a eclosão, lagartas neonatas foram individualizas em copos plásticos de $30 \mathrm{~mL}$ com tampa contendo dieta artificial para Anticarsia gemmatalis descrita por Greene et al. (1976) com modificações, onde permaneceram até atingirem a fase de pupa.

Para o preparo da dieta, todos os ingredientes autoclaváveis (Tabela 1) foram colocados em um Becker de $2000 \mathrm{~mL}$ e misturados até ficar homogêneo. O Becker foi fechado com o papel alumínio e autoclavado por 20 minutos a $120^{\circ} \mathrm{C} / 1 \mathrm{~atm}$. 
Tabela 1- Ingredientes autoclaváveis para a dieta artificial para alimentação das lagartas de $H$. armigera

\begin{tabular}{cc}
\hline Ingredientes & Quantidade \\
\hline Feijão branco triturado & $75 \mathrm{~g}$ \\
Levedo de cerveja & $37,5 \mathrm{~g}$ \\
Germén de trigo & $60 \mathrm{~g}$ \\
Proteína de soja triturada & $30 \mathrm{~g}$ \\
Leite em pó & $30 \mathrm{~g}$ \\
Ágar & $30 \mathrm{~g}$ \\
Água destilada & $1200 \mathrm{~mL}$ \\
\hline
\end{tabular}

Após a autoclavagem e com a dieta na temperatura de $60^{\circ} \mathrm{C}$ foram acrescentados os ingredientes não autoclaváveis (Tabela 2), sendo homogeneizada e vertida em um pote plástico com capacidade de $2 \mathrm{~L}$.

Tabela 2 - Ingredientes não autoclaváveis para a dieta artificial para alimentação das lagartas de H. armigera

\begin{tabular}{cc}
\hline Ingredientes & Quantidade \\
\hline Ácido ascórbico & $3,6 \mathrm{~g}$ \\
Ácido sórbico & $1,8 \mathrm{~g}$ \\
Nipagim (Metil Parabeno) & $3 \mathrm{~g}$ \\
Solução vitamínica* & $9 \mathrm{~mL}$ \\
Formol 40\% & $3,6 \mathrm{~mL}$
\end{tabular}

*Composição da solução vitamínica: $12 \mathrm{~g}$ ácido ascórbico; $0,15 \mathrm{~g}$ niacina, $0,30 \mathrm{~g}$ pantotenato de cálcio, $0,040 \mathrm{~g}$ Tiamina $\mathrm{HCl}$, 0,080 $\mathrm{g}$ Riboflavina, 0,040 g Piridoxina, 0,080 g de ácido fólico. Misturar todos os componentes em $1000 \mathrm{~mL}$ de água destilada estéril e armazenar em geladeira.

O recipiente contendo a dieta foi então deixado sob luz ultra-violeta por 20 minutos, sendo posteriormente fechado e armazenado a $8{ }^{\circ} \mathrm{C}$. Nas condições de preparo e armazenamento ideais a dieta tem uma validade de 40 dias.

As pupas foram retiradas dos potes e sexadas de acordo com a metodologia de Butt \& Cantu (1962), sendo posteriormente desinfectadas com uma solução de formol $5 \%$ por 5 minutos, água destilada por 2 minutos e sulfato de cobre $1 \%$ por 2 minutos, colocadas para secar em papel toalha. As pupas sexadas foram distribuídas de 10 em 10 em potes plásticos de $200 \mathrm{~mL}$ com tampa para emergirem separadamente (Figura 2). 


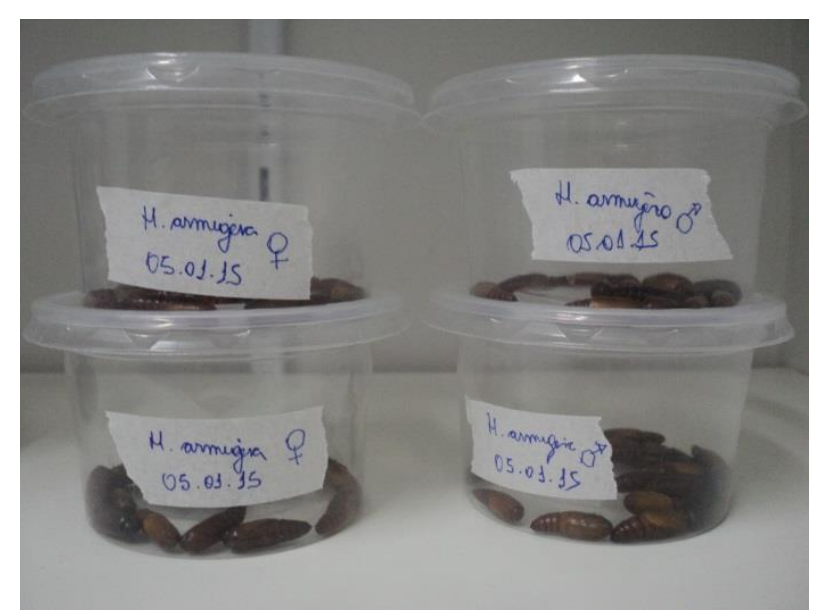

Figura 2 - Pupas de fêmeas e de machos de H. armigera.

Trinta casais de adultos recém-emergidos foram colocados em gaiolas de polietileno de 50x30x30 cm (Figura 3) e alimentados com algodão embedido na dieta líquida (75\% de dieta líquida (Tabela 3) e $25 \%$ de cerveja sem álcool) dentro de copos plásticos de $50 \mathrm{~mL}$. Para aumentar a umidade e favorecer a cópula foram colocados três copos plásticos de $50 \mathrm{~mL}$ contendo algodão molhado com água destilada.

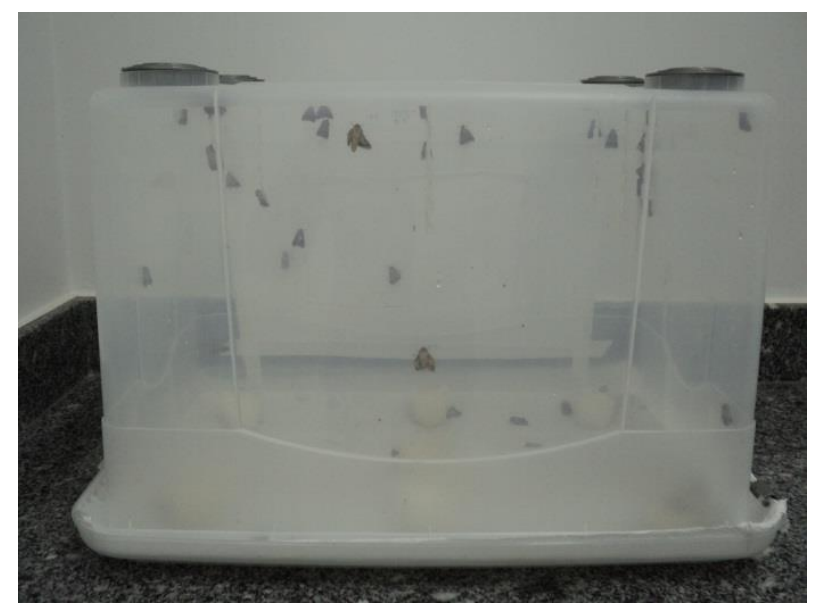

Figura 3 - Gaiola de adultos de H. armigera. 
Tabela 3 - Dieta líquida para alimentação dos adultos de H. armigera

\begin{tabular}{cc}
\hline Ingredientes & Quantidade \\
\hline Mel & $10 \mathrm{~g}$ \\
Ácido sórbico & $1 \mathrm{~g}$ \\
Nipagim (Metil Parabeno) & $1 \mathrm{~g}$ \\
Açúcar & $60 \mathrm{~g}$ \\
Água destilada & $1000 \mathrm{~mL}$ \\
\hline
\end{tabular}

A dieta líquida após completamente dissolvida pode ser armazenada a $8{ }^{\circ} \mathrm{C}$. A cerveja sem álcool foi colocada apenas no momento de ser colocada dentro da gaiola.

Para a oviposição foram colocados pedaços de barbantes de algodão desfiados pendurados na parte superior e papel toalha na base da gaiola. A cada dois dias foi montada uma nova gaiola, sendo os adultos vivos cuidadosamente transferidos e os barbantes com posturas (Figura 4) retirados e colocados em potes plásticos de $250 \mathrm{~mL}$ com tampa sem dieta artificial.

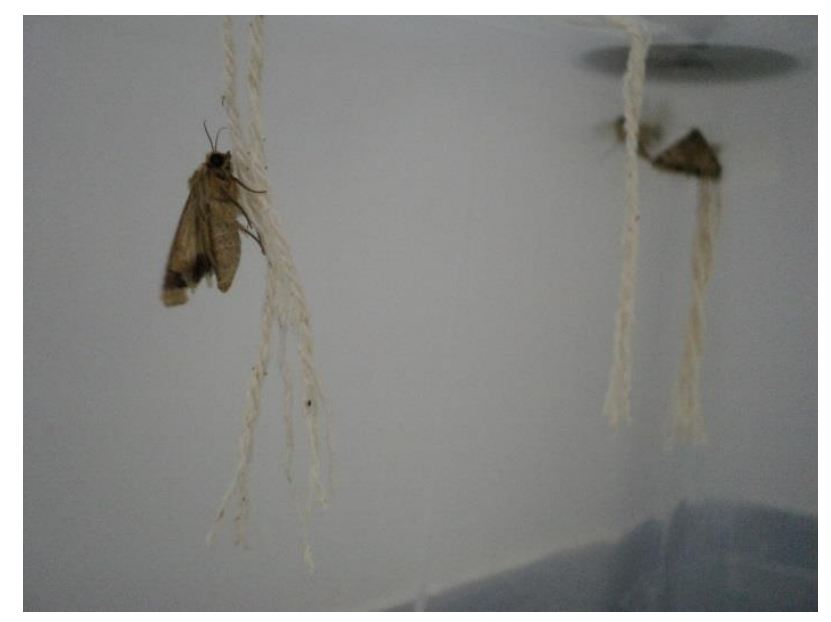

Figura 4 - Barbante de algodão perdurado na parte superior da gaiola para realização das posturas de $H$. armigera.

A eclosão das lagartas iniciou após três dias após a postura e foram cuidadosamente individualizadas para copos plásticos contendo dieta artificial. Por serem canibais o repique deve ser realizado um ou dois dias após a eclosão das lagartas (Figura 5). 


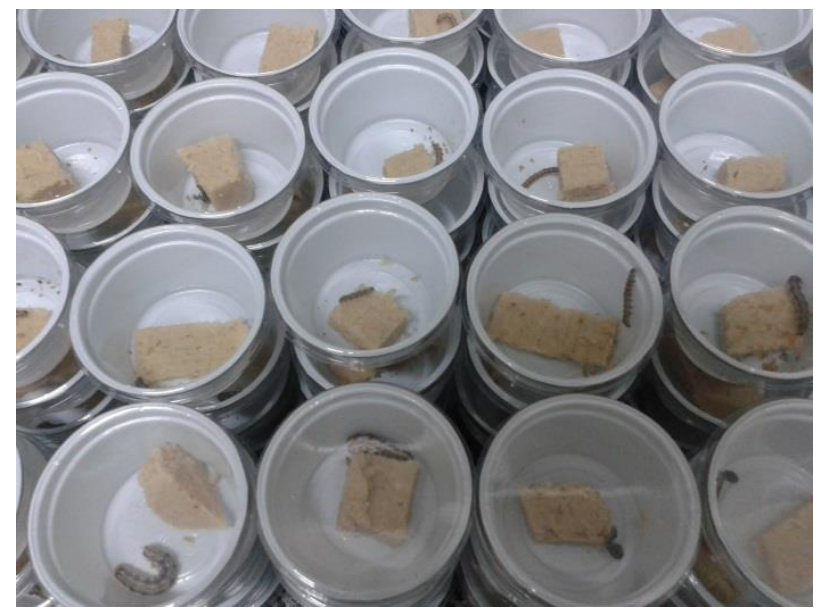

Figura 5 - Lagartas de $H$. armigera individualizadas em copos plásticos com tampa contendo dieta artificial.

Os adultos foram mantidos em salas separadas das lagartas. As condições das salas eram de umidade média de $60 \%$, temperatura de $28^{\circ} \mathrm{C} \pm 2$, fotoperíodo de $14 / 10$ horas.

A confirmação da espécie $H$. armigera foi realizada utilizando a metodologia de Behere et al. (2008).

\subsubsection{Cultivo das estirpes de Bacillus thuringiensis}

As estirpes de $B$. thuringiensis foram cultivadas em meio Embrapa (MONNERAT et al., 2007) a $28{ }^{\circ} \mathrm{C}$ por 72 horas sob agitação contínua de $200 \mathrm{rpm}$ até sua completa esporulação. Para verificar a pureza e o crescimento, uma gota do cultivo final de cada estirpes foi analisada em microscópio óptico de contraste de fases com aumento de $1000 \mathrm{X}$ para observação de esporos e cristais, sendo então, o cultivo final, utilizadas para a realização do bioensaio seletivo, caracterização bioquímica e ensaio bioquímico de promoção de crescimento vegetal.

\subsubsection{Bioensaio seletivo}

O bioensaio seletivo consistiu na busca de estirpes que tenham potencial para o controle de $100 \%$ das lagartas de H. armigera.

Para a realização dos bioensaios $35 \mu \mathrm{L}$ do cultivo final foi adicionado na dieta dos insetos previamente distribuída em placas de cultivo de células com 24 poços (Figura 6). Após a absorção da cultura pela dieta nas placas, uma lagarta neonata foi colocada em cada 
poço. Para cada estirpe foi utilizado uma placa e uma sem adição da bactéria foi utilizada como testemunha.

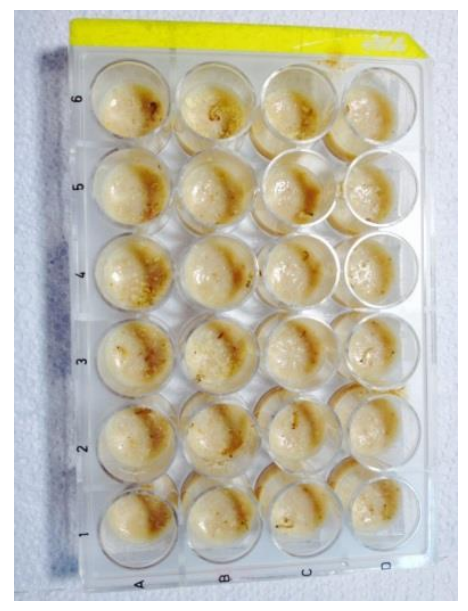

Figura 6 - Placa de cultura de células com 24 poços com dieta artifical de H. armigera.

O ensaio foi mantido nas mesmas condições da criação massal. A primeira avaliação da mortalidade foi realizada 48 horas após o início do ensaio, quando as lagartas sobreviventes foram transferidas para copos plásticos $(30 \mathrm{~mL})$ com tampa contendo dieta livre do patógeno. No sétimo dia após o início do ensaio foi realizada a segunda e última avaliação (MONNERAT et al., 2001; SILVA-WERNECK \& MONNERAT, 2001). Ao final foi determinado o número de lagartas mortas nas três repetições determinando-se a porcentagem de mortalidade. Os bioensaios foram realizados em triplicata.

\subsubsection{Caracterização bioquímica}

A caracterização do perfil protéico das estirpes que apresentaram 100\% de mortalidade para as lagartas de $H$. armigera foi analisado de acordo com o protocolo de extração de proteínas descrito por Lecadet et al., (1991) com modificações.

As culturas bacterianas foram transferidas na quantidade de $1,5 \mathrm{~mL}$ para tubos de polipropileno de 1,5 mL estéreis e, em seguida centrifugadas a $14000 \mathrm{rpm}$ (Jouan BR4i França), por 15 minutos. Os sobrenadantes foram descartados e o procedimento repetido por mais duas vezes para a obtenção do sedimento. Após a terceira centrifugação, os sobrenadantes foram descartados e o sedimento lavado com $1,5 \mathrm{~mL}$ de $\mathrm{NaCl} 5 \mathrm{M}$ e centrifugado por 15 minutos. O sobrenadante foi descartado e as paredes do tubo foram secas com papel filtro. Os sedimentos foram lavados por três vezes com 1,5 mL com uma solução 
de EDTA $100 \mathrm{mM}$ e PMSF $1 \mathrm{mM}$ e centrifugados por 15 minutos. Ao final o sobrenadante foi descartado e o sedimento contendo o complexo esporo-cristal foi ressuspenso em $300 \mu \mathrm{L}$ da solução de EDTA 100 mM e PMSF 1 mM e armazenados a $-20{ }^{\circ} \mathrm{C}$.

As análises dos perfis protéicos das estirpes foram realizadas conforme procedimento descrito por Laemmli (1970), através da eletroforese em gel de poliacrilamida-SDS a 10\% (SDS-PAGE). Alíquotas de $20 \mu \mathrm{L}$ das preparações de esporo-cristal foram diluídas em $8 \mu \mathrm{L}$ de tampão de amostra de proteína 4X (250 mM Tris-HCl, pH 6,8, 40\% Glicerol, 0,14 mM SDS, $10 \% \beta$-Mercaptoetanol, $0,1 \%$ Azul de Bromofenol) fervidas a $100{ }^{\circ} \mathrm{C}$ por 5 minutos e aplicadas em gel de poliacrilamida SDS-PAGE 10\%. Foi utilizado $5 \mu \mathrm{L}$ de marcador de proteína (marcador de massa molecular Rainbow da GE). A eletroforese foi realizada em um aparelho de eletroforese vertical (Biorad), contendo tampão de corrida 1X (Tris-base, glicina, SDS $10 \%$ ) a voltagem constante de $120 \mathrm{~V}$ por aproximadamente 1 hora e 30 minutos. $\mathrm{O}$ gel foi corado com $20 \mathrm{~mL}$ de solução corante de Comassie blue (40\% metanol e 25\% Comassie blue 250-R) por 12 horas e descorado com $20 \mathrm{~mL}$ de solução descorante (40\% de metanol, $10 \%$ ácido acético e $50 \%$ água destilada) até a visualização dos perfis protéicos das estirpes.

\subsubsection{Caracterização molecular dos genes cry}

As estirpes que apresentaram $100 \%$ de mortalidade para as lagartas de $H$. armigera foram caracterizadas quanto à presença de genes cry.

O DNA das estirpes de Bt foi extraído utilizando a metodologia descrita por Bravo et al. (1998). Para tal, as estirpes foram cultivadas em meio Ágar Embrapa (MONNERAT et al., 2007) a $30^{\circ} \mathrm{C}$ por 16 horas. Após o crescimento, uma alça (usando se alça de platina - $\emptyset: 0,5$ $\mathrm{mm}$ ) da bactéria cultivada foi colocada em $100 \mu \mathrm{L}$ de água destilada estéril em um micro tubo. Após serem vigorosamente homogeneizadas em homogeinizador tipo "vortex", as amostras foram congeladas por uma hora a $-20{ }^{\circ} \mathrm{C}$, em seguida, fervidas a $100{ }^{\circ} \mathrm{C}$ por 10 minutos e resfriadas em gelo por 2 minutos. Após este procedimento as amostras foram centrifugadas $14.000 \mathrm{rpm}$ por 2 minutos (Jouan BR4i - França) e o sobrenadante cuidadosamente transferido sem o sedimento para um tubo novo estéril.

Os iniciadores usados para cada reação estão descritos na tabela 3. O programa de PCR utilizado para a amplificação foi de $94{ }^{\circ} \mathrm{C} / 5 \mathrm{~min}, 30$ ciclos de $94{ }^{\circ} \mathrm{C} / 1 \mathrm{~min}$, anelamento (vide temperatura de anelamento, Tabela 4 ), $72{ }^{\circ} \mathrm{C} / 1$ min e $30 \mathrm{~s}$, bem como uma extensão final de $72{ }^{\circ} \mathrm{C} / 5 \mathrm{~min}$. Para a realização dos PCRs foi preparado um Mix que consiste em 0,6 $\mu \mathrm{L}$ de dNTP mix $(10 \mathrm{mM}), 1,0 \mu \mathrm{L}$ de cada iniciador $(10 \mu \mathrm{M}), 2,5 \mathrm{U}$ de Taq DNA polimerase 
e $5 \mu \mathrm{L}$ do sobrenadante em um volume total de $30 \mu \mathrm{L}$. Foram utilizados oligonucleotídeos para a identificação dos seguintes genes: cryl, cry2, cry3, cry4, cry5, cry 7 , cry8, cry9, cry 10 , cry11, cry12, cry13, cry 14, cry 17, cry 19, cry 21, cry 24, cry 25, cry 27, cry 29, cry 30, cry 32 , cry39, cry40 (CERON et al., 1995; BRAVO et al., 1998; IBARRA et al., 2003).

Tabela 4 - Características dos iniciadores utilizados para a detecção dos genes cry em estirpes de $B$. thuringiensis

\begin{tabular}{|c|c|c|c|c|c|}
\hline Oligos & Sequência & Genes & $\begin{array}{c}\text { Bandas } \\
\text { de DNA } \\
(\mathrm{pb}) \\
\end{array}$ & $\begin{array}{c}\text { Cristal } \\
\text { Protéico } \\
(\mathrm{kDa}) \\
\end{array}$ & $\begin{array}{l}\text { Tm } \\
\left({ }^{\circ} \mathrm{C}\right)\end{array}$ \\
\hline \multirow{8}{*}{$\begin{array}{l}\text { cry1 } \\
\text { Ceron et } \\
\text { al.,1995 }\end{array}$} & & crylAa & 272 & 133 & \multirow{8}{*}{48} \\
\hline & & $\operatorname{crylAb}$ & 284 & 130 & \\
\hline & & crylAc & 272 & 133 & \\
\hline & 5'TGTAGAAGAGGAAGTCTATCCA3' (d) ${ }^{1}$ & $\operatorname{crylB}$ & 290 & 140 & \\
\hline & 5’'TATCGGTTTCTGGGAAGTA3' $(\mathrm{r})^{2}$ & $\begin{array}{l}\operatorname{cry} 1 C, \\
\operatorname{cry} 1 D\end{array}$ & 284 & $132-134$ & \\
\hline & & crylEa & 275 & 133 & \\
\hline & & crylEb & 290 & 133 & \\
\hline & & crylFa & 284 & $132-134$ & \\
\hline cry1 & 5’TGTAGAAGAGGAAGTCTATCCA3' (d) & crylAa & 246 & 133 & 53 \\
\hline $\begin{array}{l}\text { Ceron } e t \\
\text { al., } 1994\end{array}$ & 5’TTGGAGCTCTCAAGGTGTAA 3’ (r) & & & & \\
\hline cry1 esp. & 5'CAGCCGATTTACCTTCTA 3' (d) & crylAd & 171 & 133 & 53 \\
\hline $\begin{array}{l}\text { Ceron } \text { et } \\
\text { al., } 1994\end{array}$ & 5'TTGGAGCTCTCAAGGTGTAA3' (r) & & & & \\
\hline cry1 esp. & 5'GTTAGATTAAATAGTAGTGG 3' (d) & crylAc & 180 & 133 & 53 \\
\hline $\begin{array}{l}\text { Ceron } e t \\
\text { al., } 1994\end{array}$ & 5’TGTAGGTGGTACTGTTATTG 3’' (r) & & & & \\
\hline cry1 esp. & 5'AACAACTATCTGTTCTTGAC3' (d) & crylAb & 216 & 130 & 53 \\
\hline $\begin{array}{l}\text { Ceron } \text { et } \\
\text { al., } 1994\end{array}$ & 5'CTCTTATTATACTTACACTAC3' (r) & & & & \\
\hline cry1 esp. & 5’CTTCATCACGATGGAGTAA3' (d) & $\operatorname{crylB}$ & 367 & 140 & 53 \\
\hline $\begin{array}{l}\text { Ceron } e t \\
\text { al., } 1994\end{array}$ & 5'CATAATTTGGTCGTTCTGTT3' (r) & & & & \\
\hline
\end{tabular}


continuação Tabela 4 - Características dos iniciadores utilizados para a detecção dos genes cry em estirpes de $B$. thuringiensis

\begin{tabular}{|c|c|c|c|c|c|}
\hline Oligos & Sequência & Genes & $\begin{array}{c}\text { Bandas } \\
\text { de DNA } \\
(\text { pb })\end{array}$ & $\begin{array}{l}\text { Cristal } \\
\text { Protéico } \\
\text { (kDa) }\end{array}$ & $\begin{array}{l}\mathbf{T m} \\
\left({ }^{\circ} \mathrm{C}\right)\end{array}$ \\
\hline $\begin{array}{l}\text { cry1 esp. } \\
\text { Ceron et } \\
\text { al., } 1994\end{array}$ & $\begin{array}{l}\text { 5'AAAGATCTGGAACACCTTT 3' (d) } \\
\text { 5'CAAACTCTAAATCCTTTCAC 3' (r) }\end{array}$ & cry1C & 130 & 134 & 53 \\
\hline $\begin{array}{l}\text { cry1 esp. } \\
\text { Ceron } \text { et } \\
\text { al., } 1994\end{array}$ & $\begin{array}{l}\text { 5'CTGCAGCAAGCTATCCAA3' (d) } \\
\text { 5'ATTTCAATTGTCAAGGCCTG3' (r) }\end{array}$ & crylD & 290 & 132 & 53 \\
\hline $\begin{array}{l}\text { cry1 esp. } \\
\text { Ceron } \text { et } \\
\text { al., } 1994\end{array}$ & $\begin{array}{l}\text { 5'GTATAAGTGGAGGGATCCATATG3' (d) } \\
\text { 5'GGATCCCTACATGTTACGCTT3' (r) }\end{array}$ & crylI & 2100 & 72 & 54 \\
\hline $\begin{array}{l}\text { cry2 } \\
\text { Bravo } \\
\text { et al., } \\
1998 \\
\end{array}$ & $\begin{array}{l}\text { 5'GAGTTTAATCGACAAGTAGATAATTT3' } \\
\text { (d) } \\
\text { 5'GGAAAAGAGAATATAAAAATGGCCAG3' } \\
\text { (r) }\end{array}$ & cry 2 & 526 & 72 & 51 \\
\hline $\begin{array}{l}\text { cry3 } \\
\text { Ceron et } \\
\text { al., } 1995\end{array}$ & $\begin{array}{l}\text { 5’TTAACCGTTTTCGCAGAGA3’ (d) } \\
\text { 5’TCCGCACTTCTATGTGTCCAAG3' (r) }\end{array}$ & $\begin{array}{l}\text { cry } 3 A \\
\text { cry } 3 B, \\
\text { cry } 3 C \\
\text { cry } 3 C b \\
\text { cry } 3 C c \\
\text { cry } 3 D \\
\text { cry } 3 F \\
\text { cry } 3 G\end{array}$ & $\begin{array}{l}703 \\
709 \\
694 \\
718 \\
652 \\
733\end{array}$ & 73 & 48 \\
\hline $\begin{array}{l}\text { cry4 } \\
\text { Ibarra et } \\
\text { al., } 2003\end{array}$ & $\begin{array}{l}\text { 5'CGTTTTCAAGACCTAATAATATAATACC3' } \\
\text { (d) } \\
\text { 5'CGGCTTGATCTATGTCATAATCTGT3' (r) }\end{array}$ & cry $4 B$ & 321 & 72 & 50 \\
\hline $\begin{array}{l}\text { cry } 5+12+ \\
14+21 \\
\text { Bravo et } \\
\text { al., } 1998\end{array}$ & $\begin{array}{l}\text { 5’TTCGTAAATTGGTCAATCAAGCAA3' (d) } \\
\text { 5'AAGACCAAATTCAATACCAGGGTT3' (r) }\end{array}$ & $\begin{array}{l}\text { cry } 5 A a, \\
\text { cry } 5 A b, \\
\text { cry } 5 A c, \\
\text { cry } 5 B \\
\text { cry } 12 \\
\text { cry } 14 \\
\text { cry } 21\end{array}$ & $\begin{array}{l}477 \\
483 \\
489\end{array}$ & $\begin{array}{c}152-142 \\
135-140 \\
142 \\
132\end{array}$ & 50 \\
\hline $\begin{array}{l}\text { cry8 } \\
\text { Bravo et } \\
\text { al., } 1998\end{array}$ & $\begin{array}{l}\text { 5’ATGAGTCCAAATAATCTAAATG 3' (d) } \\
\text { 5’TTTGATTGAATGAGTTCTTCCACTC3' (r) }\end{array}$ & $\begin{array}{l}\operatorname{cry} 8 A \\
\operatorname{cry} 8 B \\
\operatorname{cry} 8 C\end{array}$ & 376 & $\begin{array}{l}131 \\
134 \\
130 \\
\end{array}$ & 49 \\
\hline
\end{tabular}


continuação Tabela 4 - Características dos iniciadores utilizados para a detecção dos genes cry em estirpes de $B$. thuringiensis

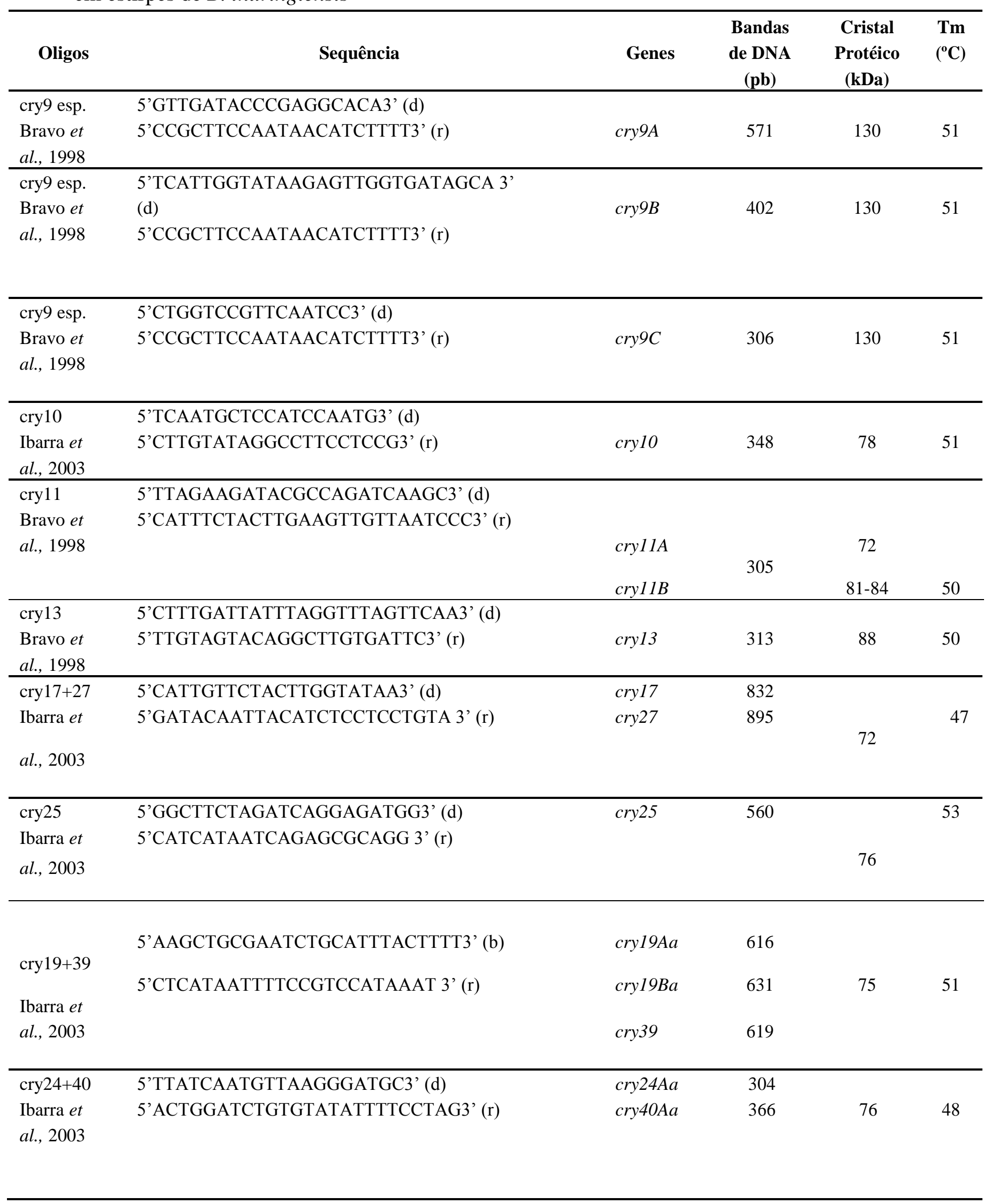


continuação Tabela 4 - Características dos iniciadores utilizados para a detecção dos genes cry em estirpes de $B$. thuringiensis

\begin{tabular}{|c|c|c|c|c|c|}
\hline Oligos & Sequência & Genes & $\begin{array}{l}\text { Bandas } \\
\text { de DNA }\end{array}$ & $\begin{array}{l}\text { Cristal } \\
\text { Protéico }\end{array}$ & $\begin{array}{l}\mathrm{Tm} \\
\left({ }^{\circ} \mathrm{C}\right)\end{array}$ \\
\hline $\begin{array}{l}\text { cry29 } \\
\text { Ibarra et } \\
\text { al., } 2003\end{array}$ & $\begin{array}{l}\text { 5'TCAGCTCCAATAACTGGTG 3' (d) } \\
\text { 5'GCATGTCATCCCCTTGTCTA3' (r) }\end{array}$ & cry 29 & 451 & 74,4 & 50 \\
\hline $\begin{array}{l}\text { cry30 } \\
\text { Ibarra et } \\
\text { al., } 2003\end{array}$ & $\begin{array}{l}\text { 5'AACTCACACATCCTCCATCG3' (d) } \\
\text { 5'ATCGAAGGCAATCATTCG3' (r) }\end{array}$ & cry 30 & 265 & 77,8 & 50 \\
\hline $\begin{array}{l}\text { cry30 } \\
\text { Ibarra } e t \\
\text { al., } 2003\end{array}$ & $\begin{array}{l}\text { 5'TGGTCGGGAGAGAATGGATGGA3' (d) } \\
\text { 5'ATGTTTGCGACACCATTTTC 3' (r) }\end{array}$ & $\begin{array}{l}\text { cry32Aa } \\
\text { cry } 32 B a \\
\text { cry32Ca } \\
\text { cry32D }\end{array}$ & $\begin{array}{l}677 \\
676\end{array}$ & 82 & 54 \\
\hline
\end{tabular}

\subsection{Determinação da capacidade de promoção de crescimento por estirpes de $B$.} thuringiensis

\subsubsection{Detecção da produção de sideróforos}

A metodologia utilizada foi a descrita por Cattelan (1999). Cem microlitros do cultivo final foram utilizados para inocular $10 \mathrm{~mL}$ de meio TSL 10 vezes diluído em erlenmeyer de $50 \mathrm{~mL}$ e, mantido sob agitação contínua de $200 \mathrm{rpm}$ a $28^{\circ} \mathrm{C}$ por 72 horas. As culturas bacterianas foram centrifugadas a $10.000 \mathrm{rpm}$ por 10 minutos (Jouan BR4i - França).

Posteriormente, a uma $\mathrm{mL}$ do sobrenadante foi adicionado uma $\mathrm{mL}$ da solução indicadora de Cromo Azurol S (CAS). Foram consideradas positivas as estirpes em que foi observada a mudança de coloração da mistura de azul para amarelo-alaranjado em 15 minutos, sendo o ensaio realizado em triplicata.

\subsubsection{Detecção e quantificação da produção de ácido indol-acético (AIA)}

Foram utilizados $100 \mu \mathrm{L}$ do cultivo final dos isolados para inocular $15 \mathrm{~mL}$ de meio DYGS em erlenmeyer de $50 \mathrm{~mL}$ (RODRIGUES NETO et al., 1986) suplementado com Ltriptofano na concentração final de $600 \mu \mathrm{g} \mathrm{mL}^{-1}$. Estes foram colocados sob agitação contínua de $200 \mathrm{rpm}$ a $28^{\circ} \mathrm{C}$ por 72 horas. Posteriormente, a cultura bacteriana foi centrifugada a 10.000 rpm por 3 minutos (Jouan BR4i - França). 
A produção de AIA foi determina pelo método colorimétrico descrito por Gordon \& Weber (1950) onde $500 \mu \mathrm{L}$ do sobrenadante foi transferido para tubos de ensaio pequenos e adicionado $1 \mathrm{~mL}$ do reagente de Salkowski $\left(1 \mathrm{ml}\right.$ de $0,5 \mathrm{M} \mathrm{FeCl}_{3}$ em $50 \mathrm{ml}$ de ácido perclórico 35\%) previamente preparado. As análises foram realizadas em triplicata e as amostras foram mantidas no escuro por 30 minutos em temperatura ambiente para posterior leitura.

A leitura da absorbância foi realizada em equipamento Picodrop Spectrometer (Pico100 - Inglaterra) com um comprimento de onda de $530 \mathrm{~nm}$. A quantificação de AIA foi avaliada utilizando uma curva de calibração de AIA sintético (Sigma) nas concentrações de 0; $1 ; 2,5 ; 5 ; 7,5$ e $10 \mu \mathrm{g} \mathrm{mL}^{-1}$.

\subsubsection{Detecção da solubilização de fosfato inorgânico}

A capacidade de solubilização de fosfato foi avalida utilizando-se a metodologia descrita por Sylvester-Bradley et al. (1982). Foi utilizado o meio GY autoclavado que ao atingir uma temperatura próxima a $50^{\circ} \mathrm{C}$, foi adicionado $50 \mathrm{~mL}$ de $\mathrm{K}_{2} \mathrm{HPO}_{4}(10 \%)$ e $100 \mathrm{~mL}$ de $\mathrm{CaCl}_{2}(10 \%)$ também autoclavados para a formação de precipitado insolúvel de $\mathrm{CaHPO}_{4} \mathrm{e}$ em seguida o meio fe cultura foi distribuído em placas de Petri. Vinte microlitros do cultivo final de cada isolado foram utilizados para a inoculação em um ponto do meio de cultura.

As placas foram mantidas no escuro em estufa de crescimento por 7 dias a $30^{\circ} \mathrm{C}$. A avaliação foi visual sendo considerado solubilizadores as estirpes que formaram um halo transparente no meio de cultura originalmente opaco. $\mathrm{O}$ ensaio foi realizado em triplicata.

\subsubsection{Detecção da capacidade de fixação assimbiótica de nitrogênio}

Para avaliar a capacidade de fixação biológica de nitrogênio $100 \mu \mathrm{L}$ de cada estirpe do cultivo final foram utilizados como inóculo em tudo de ensaio contendo $5 \mathrm{~mL}$ de meio TBNR semi-sólido isento de nitrogênio (SELDIN et al., 1984). As estirpes foram incubadas por sete dias a $30^{\circ} \mathrm{C}$ em estufa de crescimento, sendo o ensaio realizado em triplicata. Foram consideradas fixadoras as estirpes que se desenvolveram formando uma película interior do meio. 
2.2.5 Detecção de genes relacionados ao metabolismo de crescimento vegetal.

As estirpes de $B$. thuringiensis selecionadas para os ensaios in vitro quanto à presença de metabólitos secundários relacionados ao crescimento vegetal, foram caracterizadas via PCR para detecção dos genes da fosfatase ácida (metabolismo de solubilização de fosfato); sideróforos (capacidade de produzir complexos com ferro) e iam1, iam2 e ipdC (produção de ácido indol-acético).

Os iniciadores e a temperatura de anelamento usados estão descritos na tabela 5 . O DNA foi extraído e os programas de PCR utilizados foram realizados conforme descrito no item 2.1.5.

Tabela 5 - Característica dos iniciadores utilizados para detecção dos genes fosfatase ácida (metabolismo de solubilização de fosfato); sideróforos (capacidade de produzir complexos com ferro) e iam1, iam2 e ipdC (produção de ácido indol-acético) em estirpes de $B$. thuringiensis

\begin{tabular}{|c|c|c|c|c|c|}
\hline Gene alvo & $\begin{array}{l}\text { Sequência dos iniciadores } \\
\qquad\left(5^{\prime} \rightarrow 3^{\prime}\right)^{*}\end{array}$ & $\begin{array}{l}\mathrm{Tm} \\
\left({ }^{\circ} \mathrm{C}\right)\end{array}$ & $\begin{array}{l}\text { Nome do } \\
\text { iniciador }\end{array}$ & $\begin{array}{c}\text { Tamanho } \\
\text { esperado do } \\
\text { fragmento } \\
\text { amplificado }\end{array}$ & Referência \\
\hline $\begin{array}{l}\text { Biossíntese de } \\
\text { proteínas } \\
\text { Sideróforos }\end{array}$ & $\begin{array}{l}\text { GAGAATGGATTACAGAGGAT (d) } \\
\text { TTATGAACGAACAGCCACTT (r) }\end{array}$ & 55,5 & $\begin{array}{l}\text { Sider-F } \\
\text { Sider-R }\end{array}$ & $1730 \mathrm{pb}$ & $\begin{array}{c}\text { Raddadi et } \\
\text { al., } 2008 .\end{array}$ \\
\hline $\begin{array}{l}\text { Fosfatase ácida } \\
\text { (solubilização } \\
\text { de fosfato) }\end{array}$ & $\begin{array}{l}\text { AAGAGGGGCATTACCACTTTATTA (d) } \\
\text { CGCCTTCCCAATCRCCATAAT (r) }\end{array}$ & 55,5 & $\begin{array}{l}\text { AcPho-F } \\
\text { AcPho-R }\end{array}$ & $734 \mathrm{pb}$ & $\begin{array}{c}\text { Raddadi et } \\
\text { al., } 2008 .\end{array}$ \\
\hline $\begin{array}{l}\text { Triptofano } 2- \\
\text { monooxigenase } \\
\text { (Auxina) }\end{array}$ & $\begin{array}{l}\text { GTGACAGCTTTCTATCGRAA (d) } \\
\text { GTCCTTGTTCTTCCCAAAATC (r) }\end{array}$ & 55 & $\begin{array}{l}\text { IAM 1-F } \\
\text { IAM 1-R }\end{array}$ & $220 \mathrm{pb}$ & $*$ \\
\hline $\begin{array}{l}\text { Triptofano 2- } \\
\text { monooxigenase } \\
\quad \text { (Auxina) }\end{array}$ & $\begin{array}{l}\text { GGAACATCTTTTAGCTGGAGT (d) } \\
\text { TATGCAACTCTTACTCCAGAC (r) }\end{array}$ & 55 & $\begin{array}{l}\text { IAM 2-F } \\
\text { IAM 2-R }\end{array}$ & $191 \mathrm{pb}$ & $*$ \\
\hline $\begin{array}{l}\text { Indole piruvato } \\
\text { descarboxilase } \\
\text { (auxina) }\end{array}$ & $\begin{array}{l}\text { GGATAAAATGCTWCTACATGCC (d) } \\
\text { CAGTGTAGGGATGRATTTCWAT (r) }\end{array}$ & 55,5 & $\begin{array}{l}\text { ipdC-F } \\
\text { ipdC-R }\end{array}$ & $350 \mathrm{pb}$ & $*$ \\
\hline
\end{tabular}

* Nos iniciadores degenerados, a sequência é dada de acordo com código para DNA degenerado: $\mathrm{K}=\mathrm{G}$ ou T; $\mathrm{M}$ $=\mathrm{A}$ ou $\mathrm{C} ; \mathrm{W}=\mathrm{T}$ ou $\mathrm{A} ; \mathrm{Y}=\mathrm{C}$ ou $\mathrm{T} ; \mathrm{N}=\mathrm{A}, \mathrm{C}, \mathrm{G}$ ou $\mathrm{T} ; \mathrm{R}=\mathrm{A}$ ou $\mathrm{G}$. Iniciadores desenhados. 


\subsubsection{Desenho dos iniciadores}

Apesar de já existir um iniciador para detecção do gene ipdC correlato a produção de auxina (RADDADI et al., 2008), fez-se necessário a construção dos genes iam e ipdC, tendo em vista que a produção de auxina pode ser originada de duas vias distintas (Figura 7).

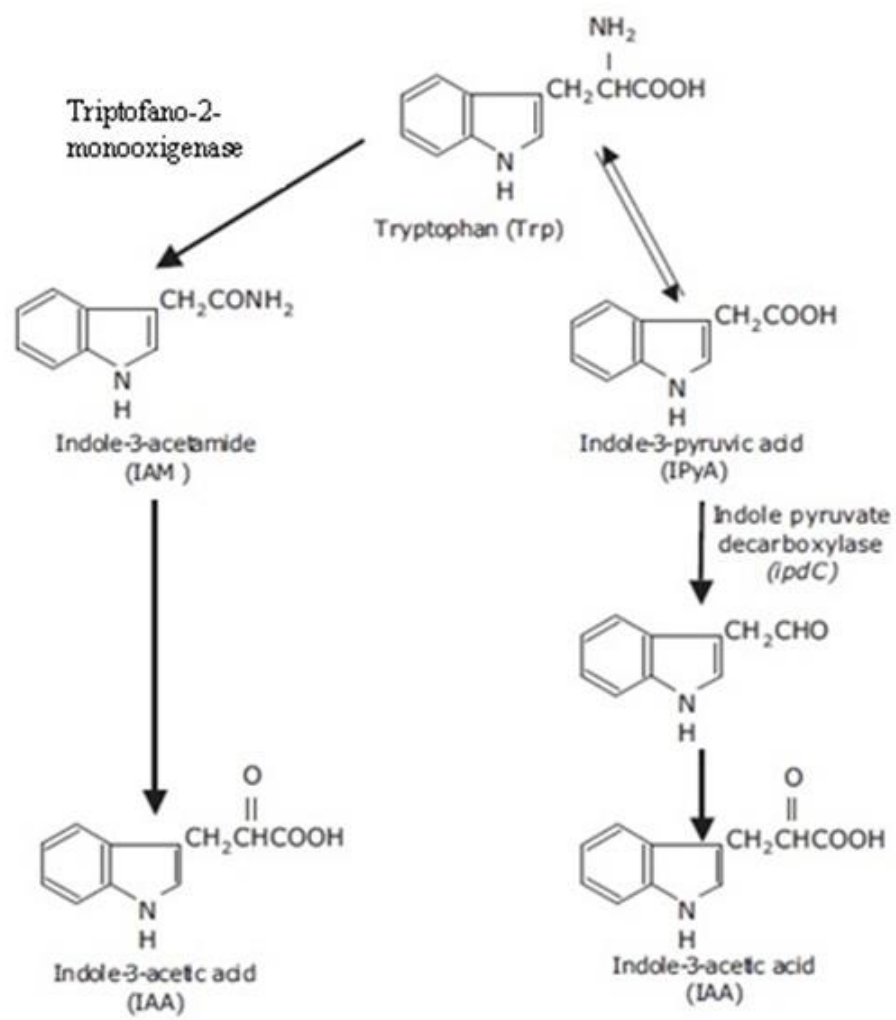

Figura 7 - Vias dependentes de triptofano para biossíntese de AIA (adaptado de Raddadi et al., 2008).

Os iniciadores específicos para a amplificação dos genes alvos foram desenhados com o auxílio do programa Vector NTI Advance 10 (Invitrogen). Foram desenhados para anelar internamente na sequência do gene alvo, de acordo com as sequências depositadas no GenBank (NCBI, 2012) (Tabela 6). 
Tabela 6- Característica dos iniciadores desenhados para a detecção dos genes iam1, iam2 e ipdC em estirpes de $B$. thuringiensis

\begin{tabular}{|c|c|c|c|c|}
\hline Gene alvo & $\begin{array}{l}\text { Sequência dos iniciadores } \\
\qquad\left(5^{\prime} \rightarrow 3^{\prime}\right)^{*}\end{array}$ & $\begin{array}{l}\mathrm{Tm} \\
\left({ }^{\circ} \mathrm{C}\right)\end{array}$ & $\begin{array}{l}\text { Nome do } \\
\text { iniciador }\end{array}$ & $\begin{array}{c}\text { Número de acesso ao Genbank das } \\
\text { sequências utilizadas }\end{array}$ \\
\hline $\begin{array}{l}\text { Triptofano 2- } \\
\text { monooxigenase }\end{array}$ & $\begin{array}{l}\text { GTGACAGCTTTCTATCGRAA (d) } \\
\text { GTCCTTGTTCTTCCCAAAATC (r) }\end{array}$ & 55 & Iaam 1 & $\begin{array}{l}\text { NC_020376.1 (1999427-2000890) } \\
\text { NC_016779.1 (1876211-1877674) }\end{array}$ \\
\hline $\begin{array}{l}\text { Triptofano 2- } \\
\text { monoxigenase }\end{array}$ & $\begin{array}{l}\text { GGAACATCTTTTAGCTGGAGT (d) } \\
\text { TATGCAACTCTTACTCCAGAC (r) }\end{array}$ & 55 & Iaam 2 & $\begin{array}{l}\text { NC_020376.1 (1908949-1901385) } \\
\text { NC_016779.1 (1787162-1788598) }\end{array}$ \\
\hline $\begin{array}{l}\text { Indole piruvato } \\
\text { descarboxilase }\end{array}$ & $\begin{array}{l}\text { GGATAAAATGCTWCTACATGCC (d) } \\
\text { CAGTGTAGGGATGRATTTCWAT (r) }\end{array}$ & 55,5 & IpdC & $\begin{array}{l}\text { NC_017200.1 (2484577-2486253) } \\
\text { NC_005957.1 (2363214-2364899) } \\
\text { NC_029238.1 (2576894-2578570) } \\
\text { NC_016771.1 (2369127-2370812) } \\
\text { NC_006274.1 (2361116-2362801) } \\
\text { NC_018491.1 (4403919-4405595) } \\
\text { NC_003909.8 (2399931-2401616) } \\
\text { NC_014171.1 (2326979-2328655) } \\
\text { NC_018693.1 (1645667-1647343) } \\
\text { NC_017208.1 (2404832-2406508) }\end{array}$ \\
\hline
\end{tabular}




\section{RESULTADOS E DISCUSSÃO}

\subsection{Criação massal de Helicoverpa armigera}

A identificação e a confirmação de que os insetos utilizados na criação massal eram $H$. armigera foi de extrema importância já que cada espécie possui diferente suscetibilidade às toxinas de Bt.

O perfil RLFP-PCR obtido foi semelhante ao encontrado por Behere et al. (2008). Utilizando-se os iniciadores para o gene citocromo oxidase subunidade I (COI) obteve-se um fragmento de amplificação de 511 pb e seguindo-se a digestão desse fragmento com a enzima de restrição BstZ17I, obteve-se um perfil de restrição com fragmentos de 318 pb e 193 pb e outro de 511 pb (Figura 8). O teste molecular confirmou que a criação massal estabelecida e os estudos realizados neste trabalho foram para a espécie $H$. armigera.

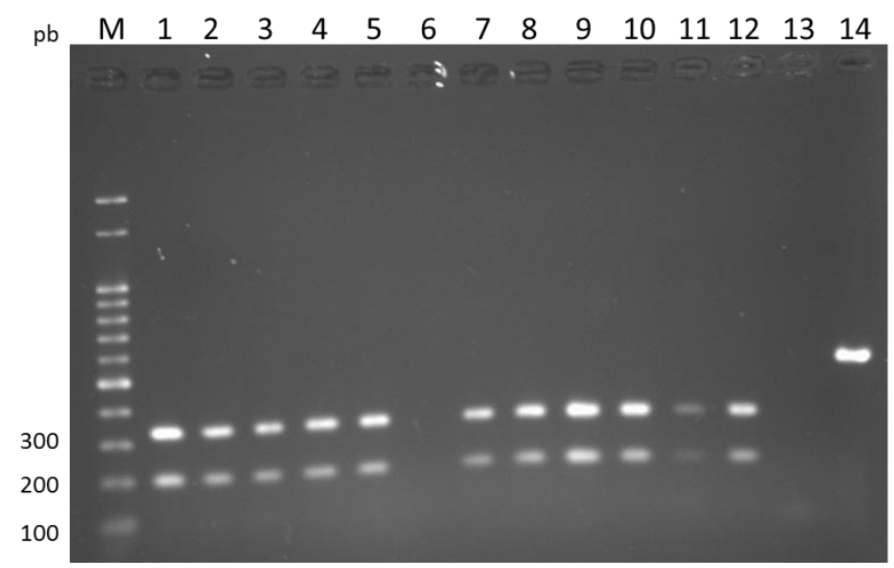

Figura 8 - Padrão de RFLP-PCR digerido com a enzima BstZ17I. Eletroforese em gel de agarose a 1,0\%, mostrando em M, marcador $100 \mathrm{pb}$ da Ludwing; $1-5$ e 7-12 produto de amplificação correspondente para $H$. armigera; 14: produto de amplificação correspondente para H. zea.

As lagartas de $H$. armigera eclodiram e cresceram nas condições de temperatura, umidade relativa do ar e fotoperíodo utilizado neste trabalho.

As fêmeas realizavam a maioria das posturas nos barbantes de algodão (Figura 9) e um pouco no papel toalha colocada no fundo da gaiola.

De acordo com Mensah (1996), as fêmeas procuram ovipositar na face adaxial das folhas ou sobre talos, flores, frutos e brotações terminais com superfícies pubescentes. Como 
o barbante imitava uma superfície pubescente, isso pode explicar a preferência pela oviposição.

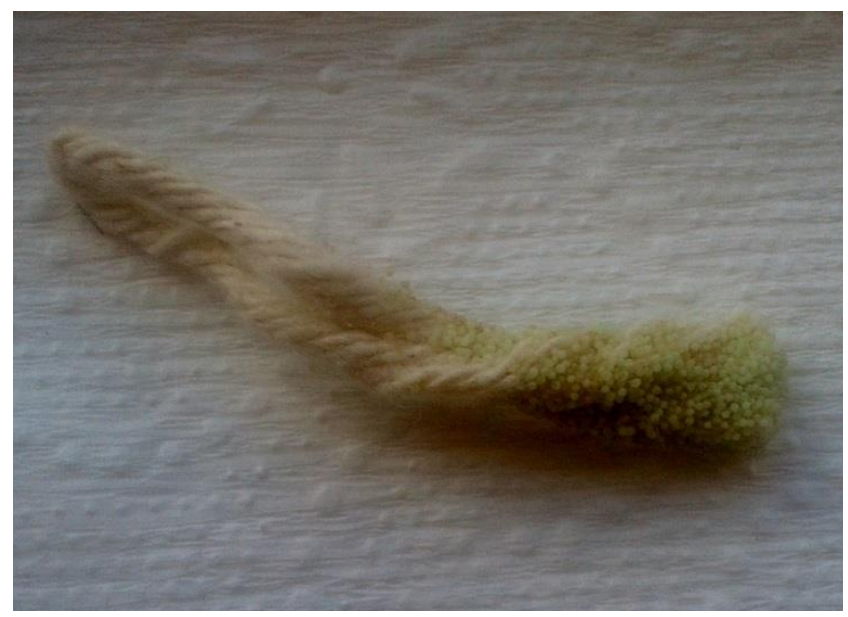

Figura 9 - Barbante de algodão com ovos de H. armigera.

O período de incubação dos ovos foi de 3 a 4 dias corrobando com Ali \& Choudhry (2009). O período larval durou aproximadamente 20 dias e a coloração variou de verde ao amarelo claro, marrom, avermelhado ou preto, cápsula cefálica de cor parda clara e linhas finas brancas laterais (Figura 10), como descrito por Czepak et al. (2013).

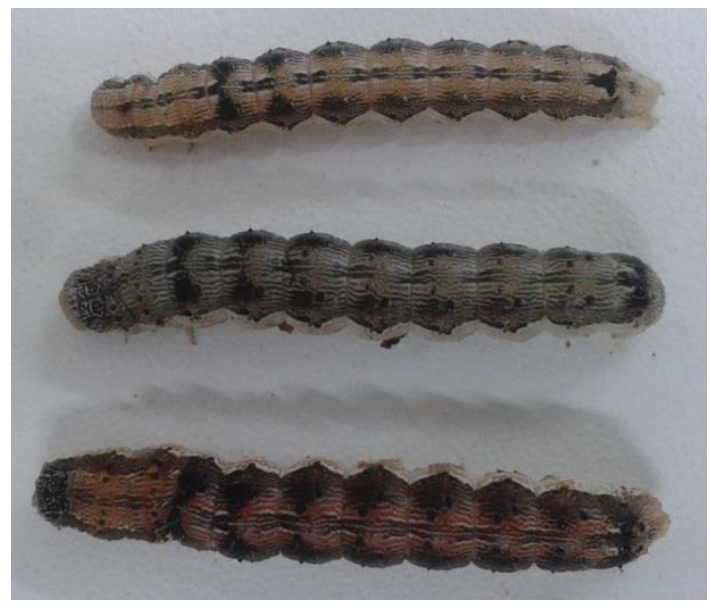

Figura 10 - Lagartas de H. armigera de diferentes colorações. 
As pupas apresentaram coloração marrom-mogno e superfície arredondada nas partes terminais como descrito por Ali \& Choudhry (2009). O período de pupa durou aproximadamente 10 dias.

As fêmeas têm o primeiro par de asas de cor marrom alaranjado ao passo que os machos têm seu primeiro par de asas de cor cinza esverdeado (CZEPAK et al., 2013), características encontradas nos adultos da criação, podendo ser verificado na Figura 11.

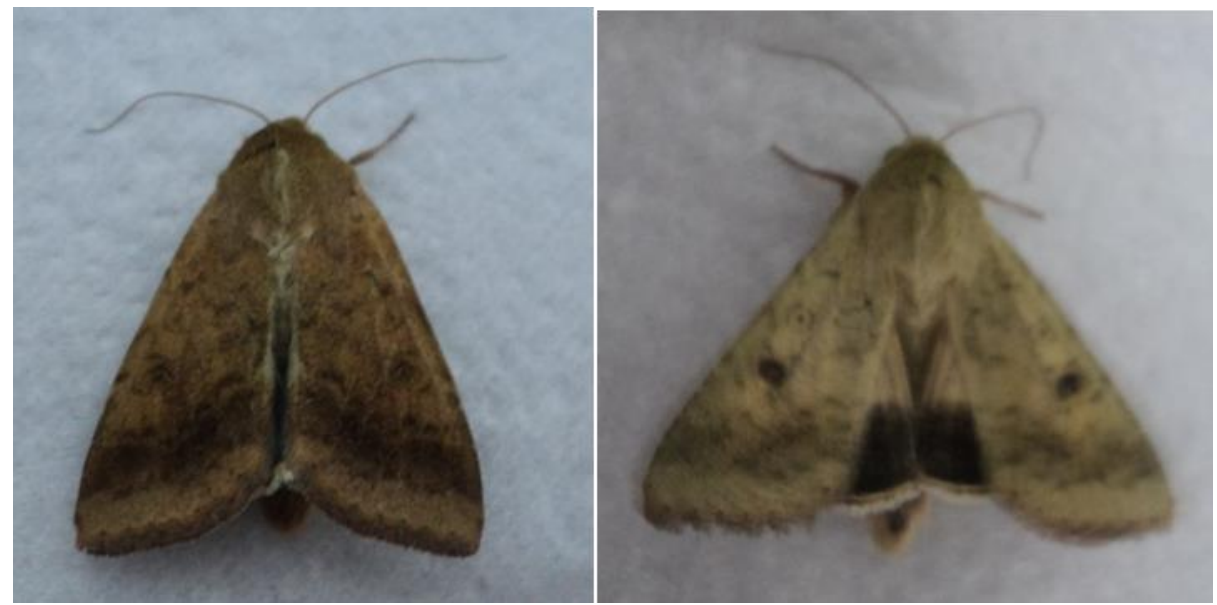

Figura 11 - Mariposas de H. armigera - fêmea (esquerda) e macho (direita).

A metodologia de criação desenvolvida permitiu a obtenção de indivíduos saídos de $H$. armigera em quantidade suficiente para a realização dos bioensaios com B. thuringiensis.

\subsection{Bioensaio seletivo}

Dentre as 100 estirpes testadas, 23 apresentaram 100\% de mortalidade contra lagartas de $H$. armigera. Pode-se observar que quinze estirpes tóxicas foram pertencentes aos sorotipos kurstaki (S607, S845, S1258, S1264, S1450-HD1, S1905, S2122, S2124), aizawai (S616, S1295), tolworthi (S1304), fokuokaensis (S608), sotto (S615), morrisoni (S1301), thuringiensis (S1269) e oito estirpes sem subespécie identificadas.

As outras 77 estirpes apresentaram mortalidade inferior a 100\%. A testemunha apresentou apenas $10 \%$ de mortalidade.

Estirpes pertencentes ao sorotipo kurstaki são consideradas as mais tóxicas para insetos da ordem Lepidoptera (AZZOUZ et al., 2014), porém as estirpes pertencentes ao 
sorotipo morrisoni (MACEDO et al., 2012; APAYDIN et al., 2008), aizawai (SHOJAADDINI et al., 2012), sotto (GUERCHICOFF et al., 2001), fokuokaensis (MELATTI et al., 2005) e thuringiensis (JAQUET et al., 1987), também apresentam alta atividade inseticida contra insetos lepidópteros, corroborando os resultados encontrados neste trabalho.

Entretanto as estirpes pertencentes aos sorotipos alesti, darmstadiensis, entomocidus, galleriae, japonensis, israelensis, kumomatoensis, kenyae, muju não apresentaram $100 \%$ de mortalidade.

B. thuringiensis subsp. israelensis possui atividade tóxica para diversos insetos da ordem Diptera (MONNERAT et al., 2006; BERRY et al., 2002). A subespécie darmstadiensis não foi tóxica quanto testada contra lagartas de Pieris brassicae e Heliothis virescens, porém foi tóxica para Spodoptera littoralis. Já a subespécie kenyae é toxica para $H$. virescens e não é tóxica para S. littoralis (JAQUET et al., 1987). Macedo et al. (2012), verificou que a subespécie galleriae possui toxicidade contra Diatreae saccharalis o que não foi observado nesse trabalho para $H$. armigera.

Os resultados da média de mortalidade de todas as estirpes pode ser visualizado na tabela 7.

Tabela 7 - Resultados de bioensaio seletivo contra H. armigera

\begin{tabular}{cccccc}
\hline Estirpes & Sorotipo & $\begin{array}{c}\text { Mortalidade } \\
(\boldsymbol{\%})\end{array}$ & Estirpes & Sorotipo & $\begin{array}{c}\text { Mortalidade } \\
(\%)\end{array}$ \\
\hline S29 & $\mathrm{Ns}$ & 51,5 & $\mathrm{~S} 1258$ & Kurstaki & 100 \\
S40 & $\mathrm{Ns}$ & 75 & $\mathrm{~S} 1261$ & $\mathrm{Ns}$ & 100 \\
S62 & Tolworthi & 71 & $\mathrm{~S} 1262$ & ostriniae & 71 \\
S93 & $\mathrm{Ns}$ & 100 & $\mathrm{~S} 1264$ & kurstaki & 100 \\
S165 & Israelensis & 62,5 & $\mathrm{~S} 1269$ & thuringiensis & 100 \\
S202 & Tochigiensis & 21 & $\mathrm{~S} 1271$ & alesti & 33 \\
S392 & $\mathrm{Ns}$ & 37,5 & $\mathrm{~S} 1272$ & $\mathrm{Ns}$ & 62,5 \\
S406 & $\mathrm{Ns}$ & 50 & $\mathrm{~S} 1275$ & $\mathrm{Ns}$ & 54 \\
S407 & $\mathrm{Ns}$ & 46 & $\mathrm{~S} 1285$ & $\mathrm{Ns}$ & 50 \\
S408 & $\mathrm{Ns}$ & 37 & $\mathrm{~S} 1286$ & $\mathrm{Ns}$ & 80 \\
S411 & $\mathrm{Ns}$ & 71 & $\mathrm{~S} 1287$ & $\mathrm{Ns}$ & 100 \\
S456 & Entomocidus & 37 & $\mathrm{~S} 1288$ & israelensis & 58 \\
S459 & Tolworthi & 25 & $\mathrm{~S} 1289$ & Ns & 100 \\
S467 & $\mathrm{Ns}$ & 80 & $\mathrm{~S} 1290$ & Ns & 92 \\
\hline
\end{tabular}

(Ns) não sorotipadas 
continuação Tabela 7 - Resultados de bioensaio seletivo contra H. armigera

\begin{tabular}{|c|c|c|c|c|c|}
\hline Estirpes & Sorotipo & $\begin{array}{c}\text { Mortalidade } \\
\qquad(\%)\end{array}$ & Estirpes & Sorotipo & $\begin{array}{c}\text { Mortalidade } \\
(\%)\end{array}$ \\
\hline $\mathrm{S} 490$ & Ns & 71 & S1291 & israelensis & 25 \\
\hline S511 & Ns & 71 & S1292 & israelensis & 37,5 \\
\hline S550 & Kurstaki & 75 & S1295 & aizawai & 100 \\
\hline S597 & Galleriae & 42 & S1301 & morrisoni & 100 \\
\hline S599 & Kenyae & 79 & S1304 & tolworthi & 100 \\
\hline S601 & $\mathrm{Ns}$ & 100 & S1307 & $\mathrm{Ns}$ & 100 \\
\hline S602 & Ns & 75 & S1342 & Ns & 50 \\
\hline S607 & Kurstaki & 100 & S1365 & pakistani & 71 \\
\hline S608 & Fokuokaensis & 100 & S1450 HD-1 & kurstaki & 100 \\
\hline S612 & Darmstadiensis & 33 & S1457 & kumomatoensis & 92 \\
\hline S615 & Sotto & 100 & S1530 & $\mathrm{Ns}$ & 29 \\
\hline S616 & Aizawai & 100 & S1704 & Ns & 12 \\
\hline S617 & Kenyae & 64,5 & S1806 & israelensis & 50 \\
\hline S655 & Alesti & 21 & S1905 & kurstaki & 100 \\
\hline S700 & Ostriniae & 29 & S1974 & $\mathrm{Ns}$ & 79 \\
\hline S711 & Japonensis & 33 & S1975 & $\mathrm{Ns}$ & 79 \\
\hline S728 & Thuringiensis & 33 & S1976 & Ns & 37 \\
\hline S755 & Ns & 42 & S1977 & Ns & 46 \\
\hline S763 & $\mathrm{Ns}$ & 50 & S1978 & Ns & 50 \\
\hline S764 & Kurstaki & 48 & S1979 & Ns & 100 \\
\hline S844 & Ns & 54 & S1982 & Ns & 58 \\
\hline S845 & Kurstaki & 100 & S1983 & Ns & 46 \\
\hline S907 & Ns & 54 & S1984 & Ns & 62 \\
\hline S1026 & Ns & 37 & S1985 & Ns & 54 \\
\hline S1067 & Ns & 71 & S1986 & Ns & 33 \\
\hline S1089 & Ns & 58 & S1989 & Ns & 58 \\
\hline S1092 & Ns & 67 & S1990 & $\mathrm{Ns}$ & 37 \\
\hline S1094 & Ns & 54 & S1995 & Ns & 67 \\
\hline S1166 & Мији & 75 & S2001 & Ns & 87 \\
\hline S1167 & Darmstadiensis & 54 & S2004 & Ns & 71 \\
\hline S1179 & Ns & 62,5 & S2005 & Ns & 96 \\
\hline S1185 & Entomocidus & 46 & S2006 & Ns & 58 \\
\hline S1191 & Ns & 100 & S2007 & Ns & 58 \\
\hline S1192 & Sotto & 50 & S2021 & Ns & 42 \\
\hline S1225 & Ns & 33 & S2122 & kurstaki & 100 \\
\hline S1257 & Ns & 46 & S2124 & kurstaki & 100 \\
\hline
\end{tabular}

(Ns) não sorotipadas 
Os produtos existentes no mercado são a maioria formulações baseadas nas estirpes $B$. thuringiensis subsp. kurstaki HD-1 (HARRISON \& BONNING, 2000), B. thuringiensis subsp. israelensis e B. thuringiensis subsp. azaiwai (BRAVO et al., 2011).

Este trabalho mostrou que lagartas de $H$. armigera são altamente susceptíveis a outras subespécies de $B$. thuringiensis além das presentes nos produtos biológicos já disponíveis no mercado, aumentando assim as possibilidades de controle e diminuindo o risco de selecionar insetos resistentes às toxinas de B. thuringiensis.

\subsection{Caracterização bioquímica e molecular de genes cry das estirpes de $B$. thuringiensis}

Foram caracterizadas de acordo com o seu perfil protéico e genes cry das 23 estirpes que apresentaram $100 \%$ de mortalidade à $H$. armigera .

Por meio da análise da eletroforese em gel de poliacrilamida (SDS-PAGE-10\%) da mistura de esporos-cristais (Figura 12), foi possível observar que 10 estirpes eram compostas de dois polipeptídios principais de aproximadamente 130 e $65 \mathrm{kDa}$ semelhantes entre si e ao perfil do padrão B. thuringiensis subsp. kurstaki HD-1 (HOFTE e WHITELEY, 1989). As outras estirpes apresentaram apenas a presença de um desses polipeptídios, sendo que 9 estirpes apresentaram apenas a proteína de $130 \mathrm{kDa}$ e as S93, S608 e S1289 apresentaram apenas a proteína de $65 \mathrm{kDa}$.

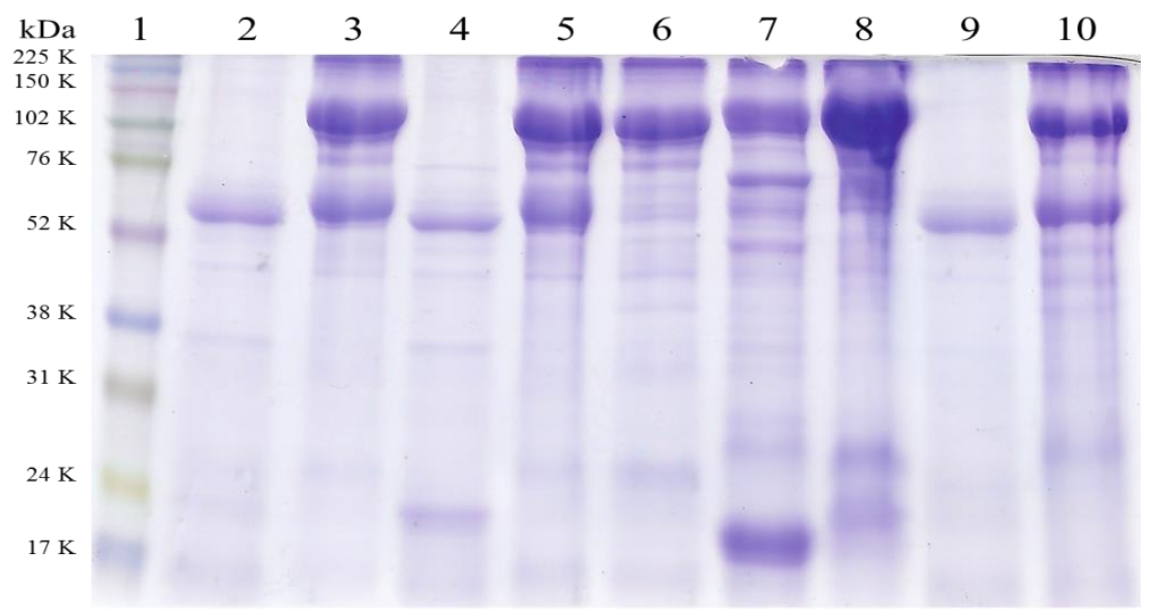

Figura 12 - Perfil protéico das estirpes selecionadas de B. thuringiensis. A preparação esporo/cristal das culturas foi submetida à eletroforese em gel de acrilamida 10\%. 1: marcador de massa molecular Rainbow (GE); 2: S93; 3: S607; 4: S608; 5: S1191; 6: S1264; 7: 1269; 8: S1287; 9: S1289; 10: S1304. 
Proteínas de massa molecular de $130 \mathrm{kDa}$ estão relacionadas com o padrão característico das proteínas da família Cry1, que são efetivas contra coleópteros e lepidópteros (BRAVO et al., 2004) e o perfil de 65 kDa é característico das proteínas da família Cry2, que é ativa contra lepidópteros e dípteros (CRICKMORE et al., 1998; BRAVO et al., 2004).

Foram obtidos por meio de PCR amplicons de tamanho esperados para a detecção de genes das classes cry1 e cry2, não sendo obtido nenhum resultado positivo para os outros iniciadores testados.

Os amplicons com maior frequência nas estirpes testadas foram correspondentes aos genes crylAa (13 estirpes), crylAb (19), crylAc (10), crylB (12), cry2Aa (14) e cry2Ab (17). Seis estirpes apresentaram amplicons para o gene crylE, quatro para crylF e três para cry1Ad, crylD e crylG, Apenas as estirpes S1295 e S2122 apresentaram amplicons para o gene $\operatorname{cry} 1 C$.

Os resultados do perfil protéico e da caracterização molecular das estirpes com mortalidade de $100 \%$ para $H$. armigera pode ser visualizado na tabela 8 .

Tabela 8 - Estirpe, sorotipo, conteúdo gênico e perfil protéico das estirpes de $B$. thuringiensis que apresentaram $100 \%$ de mortalidade à $H$. armigera

\begin{tabular}{|c|c|c|c|}
\hline Estirpes & Sorotipo & Conteúdo gênico & $\begin{array}{c}\text { Perfil protéico } \\
\text { (kDa) }\end{array}$ \\
\hline S93 & Ns & crylAa, crylAb, crylAc, cry $2 A a$ & 65 \\
\hline S601 & Ns & $\operatorname{cry} 1 B$ & 130 \\
\hline S607 & kurstaki & crylAa, cry $1 A b$, cry $1 A c$, cry $1 B$, cry $2 A a$, cry $2 A b$ & $130-65$ \\
\hline S608 & fokuokaensis & cry, $1 A a$, cry $1 A b$, cry $1 A c$, cry $1 E$, cry $2 A a$, cry $2 A b$ & 65 \\
\hline S615 & sotto & cry $1 A b$, cry $1 A c$, cry $1 B$, cry $1 G$, cry $2 A a$, cry $2 A b$ & $130-65$ \\
\hline S616 & aizawai & crylAa, crylAb, crylAd, crylE, cry $1 F$, cry $2 A b$ & $130-65$ \\
\hline S845 & kurstaki & $\operatorname{cry} 1 A a$, cry $1 B$, cry $2 A b$ & 130 \\
\hline S1191 & Ns & cry $1 A a$, cry $1 A b$, cry $1 A c$, cry $1 B$, cry $2 A a$, cry $2 A b$ & $130-65$ \\
\hline S1258 & kurstaki & cry $1 A a$, cry $1 A b$, cry $1 A c$, cry $1 B$, cry $2 A a$, cry $2 A b$ & $130-65$ \\
\hline S1261 & Ns & $\operatorname{cry} 1 A c$, cry $1 E$, cry $2 A a$, cry $2 A b$ & 130 \\
\hline S1264 & kurstaki & crylAb, crylAc, cry $2 A a$ & 130 \\
\hline S1269 & thuringiensis & $\operatorname{cry} l A c, \operatorname{cry} l B$ & 130 \\
\hline S1287 & Ns & crylAb, crylB, crylF, crylG & 130 \\
\hline S1289 & Ns & cry $1 A b$, cry $1 A d$, cry $2 A b$ & 65 \\
\hline S1295 & aizawai & crylAa, crylAb, cry $1 C$, cry $1 D$, cry $1 E$, cry $2 A b$ & 130 \\
\hline S1301 & morrisoni & crylAb, crylD, crylF, crylG & 130 \\
\hline S1304 & tolworthi & $\operatorname{cry} 1 A b$, cry $1 B$, cry $1 E$, cry $2 A a$, cry $2 A b$ & $130-65$ \\
\hline S1307 & Ns & cry $1 A a$, cry $1 A b$, cry $1 B$, cry $1 E$, cry $2 A a$, cry $2 A b$ & $130-65$ \\
\hline S1450 HD-1 & kurstaki & cry $1 A a$, cry $1 A b$, cry $1 A c$, cry $1 B$, cry $2 A a$, cry $2 A b$ & $130-65$ \\
\hline
\end{tabular}


continuação Tabela 8 - Estirpe, sorotipo, conteúdo gênico e perfil protéico das estirpes de $B$. thuringiensis que apresentaram $100 \%$ de mortalidade à $H$. armigera

\begin{tabular}{cccc}
\hline Estirpes & Sorotipo & Conteúdo gênico & $\begin{array}{c}\text { Perfil protéico } \\
\text { (kDa) }\end{array}$ \\
\hline S1905 & kurstaki & crylAa, crylAb, crylAc, crylB, cry2Aa, cry2Ab & $130-65$ \\
S1979 & Ns & crylAa, crylAb, crylAc, crylB, cry2Aa, cry2Ab & $130-65$ \\
S2122 & kurstaki & crylAa, crylAb, crylAd, crylC, crylD, crylF, cry2Ab & 130 \\
S2124 & kurstaki & crylAb, crylE, cry2Aa, cry2Ab & $130-65$ \\
\hline
\end{tabular}

As estirpes S607, S1191, S1258, S1905, S1979 apresentaram perfil protéico e gênico semelhantes ao da estirpe padrão S1450 Btk HD-1 (crylAa, crylAb, crylAc, crylB, cry2Aa e cry $2 A b$ ), sendo que apenas a S1191 e S1979 não são consideradas B. thuringiensis subsp. kurstaki por ainda não terem sido identificadas. Com o fechamento do Instituto Pasteur em 2000 a obtenção do anticorpo para sorotipagem tornou-se mais difícil, não permitindo identificação das subespécies das estirpes.

As proteínas Cry1Aa, Cry1Ab, Cry1Ac, Cry2Aa, Cry2Ab são descritas tóxicas para $H$. armigera (CHAKRABARTI et al., 1998; LIAO et al., 2002).

As duas estirpes que apresentaram amplicon para o gene crylC apresentaram também para o gene crylAa. Estudos observaram que a toxina Cry1C possui um sinergismo com a toxina Cry1Aa em lagartas de H. armigera (XUE et al., 2005; LI \& BOUWER, 2014).

Estudo realizado por Ben-Dov et al. (1997) encontrou em B. thuringiensis subsp. aizawai HD-133 a presença dos genes crylAa, crylAb, crylC, crylD, cry2Ab; $B$. thuringiensis subsp. tolworthi HDB-8 os genes crylAb, cry $2 A a$, cry $2 A b ; B$. thuringiensis subsp. thuringiensis HD-2 o gene crylB; B. thuringiensis subsp. kurstaki HD-1 os genes crylAa, crylAb, crylAc, cry $2 A a$, cry $2 A b$, corroborando com os resultados encontrados neste trabalho.

A proteína Cry1B, possui massa molecular de $140 \mathrm{kDa}$ e é tóxica aos lepidópteros e aos coleópteros (TAILOR et al., 1992). A proteína Cry1F já foi encontrada em $B$. thuringiensis subsp. aizawai e morrisoni (CRICKMORE et al., 2015) e subsp. kurstaki (MACEDO et al., 2012), corroborando com o resultado encontrado.

As proteínas Cry2Aa apresentam toxicidade aos lepidópteros e aos dípteros, enquanto a Cry2Ab possui atividade somente contra lepidópteros (Bravo et al., 2004).

Em pesquisas futuras bioensaios de dose devem ser realizados para a determinação da CL50 das 23 estirpes, bem como para as toxinas individualizadas e em conjunto, visando 
confirmar quais são responsáveis pela mortalidade das lagartas de $H$. armigera e avaliar se há um possível efeito sinérgico.

Novos bioinseticidas formulados com $B$. thuringiensis de diferentes subespécies e que contenham diferentes genes são importantes para o manejo da resistência de insetos.

\subsection{Determinação da capacidade de promoção de crescimento por estirpes de $\boldsymbol{B}$. thuringiensis}

As 100 estirpes de $B$. thuringiensis analisadas neste trabalho não apresentaram capacidade de fixação de nitrogênio, solubilização de fosfato e produção de sideróforos in vitro. $100 \%$ das amostras foram positivas para a produção de AIA. A quantidade de AIA variou de $1,17 \mu \mathrm{g} \mathrm{mL}^{-1}$ (estirpe S93) a 7,44 $\mu \mathrm{g} \mathrm{mL}^{-1}$ (estirpe 1983) (Tabela 9).

Das estirpes testadas 16 apresentaram produção de AIA entre 1 e $2 \mu \mathrm{g} \mathrm{mL} \mathrm{m}^{-1}, 52$ entre 2 e $3 \mu \mathrm{g} \mathrm{mL}^{-1}$ e 26 estirpes apresentaram entre 3 e $4 \mu \mathrm{g} \mathrm{mL}{ }^{-1}$. Apenas 6 estirpes apresentaram uma produção de AIA acima de $5 \mu \mathrm{g} \mathrm{mL}^{-1}$, sendo que dessas apenas as estirpe S1292 e S1983 produziram acima de $7 \mu \mathrm{g} \mathrm{mL} \mathrm{m}^{-1}$.

Tabela 9 - Caracterização bioquímica das estirpes de B. thuringiensis na produção de metabolitos secundários com capacidade de promoção de crescimento vegetal

\begin{tabular}{|c|c|c|c|c|c|c|c|c|c|}
\hline Estirpes & $\begin{array}{l}\text { Fixação de } \\
\text { Nitrogênio }\end{array}$ & $\begin{array}{l}\text { Solubilização } \\
\text { de fosfato }\end{array}$ & $\begin{array}{l}\text { Produção } \\
\text { de } \\
\text { sideróforos }\end{array}$ & $\begin{array}{c}\text { Produção } \\
\text { de } \\
\text { auxinas } \\
\left(\mu \mathrm{g} \mathrm{mL} \mathbf{L}^{-1}\right)\end{array}$ & Estirpes & $\begin{array}{c}\text { Fixação } \\
\text { de } \\
\text { Nitrogênio }\end{array}$ & $\begin{array}{l}\text { Solubilização } \\
\text { de fosfato }\end{array}$ & $\begin{array}{l}\text { Produção } \\
\text { de } \\
\text { sideróforos }\end{array}$ & $\begin{array}{c}\text { Produção } \\
\text { de } \\
\text { auxinas } \\
\left(\mu \mathrm{g} \mathrm{mL}^{-1}\right)\end{array}$ \\
\hline S29 & $\mathrm{N}$ & $\mathrm{N}$ & $\mathrm{N}$ & 1,17 & $\mathrm{~S} 1258$ & $\mathrm{~N}$ & $\mathrm{~N}$ & $\mathrm{~N}$ & 2,91 \\
\hline S40 & $\mathrm{N}$ & $\mathrm{N}$ & $\mathrm{N}$ & 1,70 & S1261 & $\mathrm{N}$ & $\mathrm{N}$ & $\mathrm{N}$ & 2,80 \\
\hline S62 & $\mathrm{N}$ & $\mathrm{N}$ & $\mathrm{N}$ & 2,78 & S1262 & $\mathrm{N}$ & $\mathrm{N}$ & $\mathrm{N}$ & 2,82 \\
\hline S93 & $\mathrm{N}$ & $\mathrm{N}$ & $\mathrm{N}$ & 3,12 & S1264 & $\mathrm{N}$ & $\mathrm{N}$ & $\mathrm{N}$ & 2,96 \\
\hline S165 & $\mathrm{N}$ & $\mathrm{N}$ & $\mathrm{N}$ & 3,26 & S1269 & $\mathrm{N}$ & $\mathrm{N}$ & $\mathrm{N}$ & 3,37 \\
\hline S202 & $\mathrm{N}$ & $\mathrm{N}$ & $\mathrm{N}$ & 2,85 & S1271 & $\mathrm{N}$ & $\mathrm{N}$ & $\mathrm{N}$ & 1,79 \\
\hline S392 & $\mathrm{N}$ & $\mathrm{N}$ & $\mathrm{N}$ & 2,10 & $\mathrm{~S} 1272$ & $\mathrm{~N}$ & $\mathrm{~N}$ & $\mathrm{~N}$ & 2,87 \\
\hline S406 & $\mathrm{N}$ & $\mathrm{N}$ & $\mathrm{N}$ & 2,19 & S1275 & $\mathrm{N}$ & $\mathrm{N}$ & $\mathrm{N}$ & 2,26 \\
\hline S407 & $\mathrm{N}$ & $\mathrm{N}$ & $\mathrm{N}$ & 3,16 & S1285 & $\mathrm{N}$ & $\mathrm{N}$ & $\mathrm{N}$ & 4,51 \\
\hline S408 & $\mathrm{N}$ & $\mathrm{N}$ & $\mathrm{N}$ & 2,98 & S1286 & $\mathrm{N}$ & $\mathrm{N}$ & $\mathrm{N}$ & 2,53 \\
\hline S411 & $\mathrm{N}$ & $\mathrm{N}$ & $\mathrm{N}$ & 3,39 & S1287 & $\mathrm{N}$ & $\mathrm{N}$ & $\mathrm{N}$ & 2,62 \\
\hline S456 & $\mathrm{N}$ & $\mathrm{N}$ & $\mathrm{N}$ & 3,40 & S1288 & $\mathrm{N}$ & $\mathrm{N}$ & $\mathrm{N}$ & 5,97 \\
\hline S459 & $\mathrm{N}$ & $\mathrm{N}$ & $\mathrm{N}$ & 2,20 & S1289 & $\mathrm{N}$ & $\mathrm{N}$ & $\mathrm{N}$ & 3,72 \\
\hline S467 & $\mathrm{N}$ & $\mathrm{N}$ & $\mathrm{N}$ & 3,42 & S1290 & $\mathrm{N}$ & $\mathrm{N}$ & $\mathrm{N}$ & 5,12 \\
\hline S490 & $\mathrm{N}$ & $\mathrm{N}$ & $\mathrm{N}$ & 2,69 & S1291 & $\mathrm{N}$ & $\mathrm{N}$ & $\mathrm{N}$ & 4,92 \\
\hline
\end{tabular}

(N) resultado negativo 
continuação Tabela 9 - Caracterização bioquímica das estirpes de B. thuringiensis na produção de metabolitos secundários com capacidade de promoção de crescimento vegetal

\begin{tabular}{|c|c|c|c|c|c|c|c|c|c|}
\hline Estirpes & $\begin{array}{l}\text { Fixação de } \\
\text { Nitrogênio }\end{array}$ & $\begin{array}{c}\text { Solubilização } \\
\text { de fosfato }\end{array}$ & $\begin{array}{l}\text { Produção } \\
\text { de } \\
\text { sideróforos }\end{array}$ & $\begin{array}{c}\text { Produção } \\
\text { de } \\
\text { auxinas } \\
\left(\mu \mathrm{g} \mathrm{mL} \mathbf{L}^{-1}\right)\end{array}$ & Estirpes & $\begin{array}{c}\text { Fixação } \\
\text { de } \\
\text { Nitrogênio }\end{array}$ & $\begin{array}{l}\text { Solubilização } \\
\text { de fosfato }\end{array}$ & $\begin{array}{l}\text { Produção } \\
\text { de } \\
\text { sideróforos }\end{array}$ & $\begin{array}{c}\text { Produção } \\
\text { de } \\
\text { auxinas } \\
\left(\mu \mathrm{g} \mathrm{mL}^{-1}\right)\end{array}$ \\
\hline S511 & $\mathrm{N}$ & $\mathrm{N}$ & $\mathrm{N}$ & 3,26 & S1292 & $\mathrm{N}$ & $\mathrm{N}$ & $\mathrm{N}$ & 7,18 \\
\hline S550 & $\mathrm{N}$ & $\mathrm{N}$ & $\mathrm{N}$ & 1,55 & S1295 & $\mathrm{N}$ & $\mathrm{N}$ & $\mathrm{N}$ & 2,71 \\
\hline S597 & $\mathrm{N}$ & $\mathrm{N}$ & $\mathrm{N}$ & 2,11 & S1301 & $\mathrm{N}$ & $\mathrm{N}$ & $\mathrm{N}$ & 2,35 \\
\hline S599 & $\mathrm{N}$ & $\mathrm{N}$ & $\mathrm{N}$ & 3,19 & S1304 & $\mathrm{N}$ & $\mathrm{N}$ & $\mathrm{N}$ & 5,82 \\
\hline S601 & $\mathrm{N}$ & $\mathrm{N}$ & $\mathrm{N}$ & 2,29 & S1307 & $\mathrm{N}$ & $\mathrm{N}$ & $\mathrm{N}$ & 2,82 \\
\hline S602 & $\mathrm{N}$ & $\mathrm{N}$ & $\mathrm{N}$ & 2,85 & S1342 & $\mathrm{N}$ & $\mathrm{N}$ & $\mathrm{N}$ & 2,05 \\
\hline S607 & $\mathrm{N}$ & $\mathrm{N}$ & $\mathrm{N}$ & 2,98 & S1365 & $\mathrm{N}$ & $\mathrm{N}$ & $\mathrm{N}$ & 2,31 \\
\hline S608 & $\mathrm{N}$ & $\mathrm{N}$ & $\mathrm{N}$ & 3,14 & S1450 & $\mathrm{N}$ & $\mathrm{N}$ & $\mathrm{N}$ & 3,64 \\
\hline S612 & $\mathrm{N}$ & $\mathrm{N}$ & $\mathrm{N}$ & 2,09 & S1457 & $\mathrm{N}$ & $\mathrm{N}$ & $\mathrm{N}$ & 2,84 \\
\hline S615 & $\mathrm{N}$ & $\mathrm{N}$ & $\mathrm{N}$ & 3,24 & S1530 & $\mathrm{N}$ & $\mathrm{N}$ & $\mathrm{N}$ & 2,40 \\
\hline S616 & $\mathrm{N}$ & $\mathrm{N}$ & $\mathrm{N}$ & 3,99 & S1704 & $\mathrm{N}$ & $\mathrm{N}$ & $\mathrm{N}$ & 2,62 \\
\hline S617 & $\mathrm{N}$ & $\mathrm{N}$ & $\mathrm{N}$ & 2,52 & S1806 & $\mathrm{N}$ & $\mathrm{N}$ & $\mathrm{N}$ & 3,51 \\
\hline S655 & $\mathrm{N}$ & $\mathrm{N}$ & $\mathrm{N}$ & 2,08 & S1905 & $\mathrm{N}$ & $\mathrm{N}$ & $\mathrm{N}$ & 2,74 \\
\hline S700 & $\mathrm{N}$ & $\mathrm{N}$ & $\mathrm{N}$ & 2,26 & S1974 & $\mathrm{N}$ & $\mathrm{N}$ & $\mathrm{N}$ & 3,91 \\
\hline S711 & $\mathrm{N}$ & $\mathrm{N}$ & $\mathrm{N}$ & 2,95 & S1975 & $\mathrm{N}$ & $\mathrm{N}$ & $\mathrm{N}$ & 5,02 \\
\hline S728 & $\mathrm{N}$ & $\mathrm{N}$ & $\mathrm{N}$ & 2,95 & S1976 & $\mathrm{N}$ & $\mathrm{N}$ & $\mathrm{N}$ & 4,46 \\
\hline S755 & $\mathrm{N}$ & $\mathrm{N}$ & $\mathrm{N}$ & 2,73 & S1977 & $\mathrm{N}$ & $\mathrm{N}$ & $\mathrm{N}$ & 4,13 \\
\hline S763 & $\mathrm{N}$ & $\mathrm{N}$ & $\mathrm{N}$ & 3,18 & S1978 & $\mathrm{N}$ & $\mathrm{N}$ & $\mathrm{N}$ & 2,27 \\
\hline S764 & $\mathrm{N}$ & $\mathrm{N}$ & $\mathrm{N}$ & 1,97 & S1979 & $\mathrm{N}$ & $\mathrm{N}$ & $\mathrm{N}$ & 3,17 \\
\hline S844 & $\mathrm{N}$ & $\mathrm{N}$ & $\mathrm{N}$ & 3,63 & S1982 & $\mathrm{N}$ & $\mathrm{N}$ & $\mathrm{N}$ & 2,41 \\
\hline S845 & $\mathrm{N}$ & $\mathrm{N}$ & $\mathrm{N}$ & 3,13 & S1983 & $\mathrm{N}$ & $\mathrm{N}$ & $\mathrm{N}$ & 7,44 \\
\hline S907 & $\mathrm{N}$ & $\mathrm{N}$ & $\mathrm{N}$ & 2,85 & S1984 & $\mathrm{N}$ & $\mathrm{N}$ & $\mathrm{N}$ & 2,17 \\
\hline S1026 & $\mathrm{N}$ & $\mathrm{N}$ & $\mathrm{N}$ & 2,52 & S1985 & $\mathrm{N}$ & $\mathrm{N}$ & $\mathrm{N}$ & 3,03 \\
\hline S1067 & $\mathrm{N}$ & $\mathrm{N}$ & $\mathrm{N}$ & 3,38 & S1986 & $\mathrm{N}$ & $\mathrm{N}$ & $\mathrm{N}$ & 1,83 \\
\hline S1089 & $\mathrm{N}$ & $\mathrm{N}$ & $\mathrm{N}$ & 2,96 & S1989 & $\mathrm{N}$ & $\mathrm{N}$ & $\mathrm{N}$ & 4,96 \\
\hline S1092 & $\mathrm{N}$ & $\mathrm{N}$ & $\mathrm{N}$ & 3,17 & S1990 & $\mathrm{N}$ & $\mathrm{N}$ & $\mathrm{N}$ & 2,03 \\
\hline S1094 & $\mathrm{N}$ & $\mathrm{N}$ & $\mathrm{N}$ & 2,02 & S1995 & $\mathrm{N}$ & $\mathrm{N}$ & $\mathrm{N}$ & 2,50 \\
\hline S1166 & $\mathrm{N}$ & $\mathrm{N}$ & $\mathrm{N}$ & 2,77 & S2001 & $\mathrm{N}$ & $\mathrm{N}$ & $\mathrm{N}$ & 2,87 \\
\hline S1167 & $\mathrm{N}$ & $\mathrm{N}$ & $\mathrm{N}$ & 3,27 & S2004 & $\mathrm{N}$ & $\mathrm{N}$ & $\mathrm{N}$ & 4,94 \\
\hline S1179 & $\mathrm{N}$ & $\mathrm{N}$ & $\mathrm{N}$ & 2,93 & S2005 & $\mathrm{N}$ & $\mathrm{N}$ & $\mathrm{N}$ & 4,58 \\
\hline S1185 & $\mathrm{N}$ & $\mathrm{N}$ & $\mathrm{N}$ & 2,16 & S2006 & $\mathrm{N}$ & $\mathrm{N}$ & $\mathrm{N}$ & 4,78 \\
\hline S1191 & $\mathrm{N}$ & $\mathrm{N}$ & $\mathrm{N}$ & 2,59 & S2007 & $\mathrm{N}$ & $\mathrm{N}$ & $\mathrm{N}$ & 2,71 \\
\hline S1192 & $\mathrm{N}$ & $\mathrm{N}$ & $\mathrm{N}$ & 3,99 & S2021 & $\mathrm{N}$ & $\mathrm{N}$ & $\mathrm{N}$ & 2,92 \\
\hline S1225 & $\mathrm{N}$ & $\mathrm{N}$ & $\mathrm{N}$ & 1,63 & S2122 & $\mathrm{N}$ & $\mathrm{N}$ & $\mathrm{N}$ & 3,12 \\
\hline S1257 & $\mathrm{N}$ & $\mathrm{N}$ & $\mathrm{N}$ & 2,31 & S2124 & $\mathrm{N}$ & $\mathrm{N}$ & $\mathrm{N}$ & 4,93 \\
\hline
\end{tabular}

(N) resultado negativo 
Estudo realizado por Felestrino (2013) com diferentes isolados dentre eles Bacillus spp. não obteve nenhum isolado com capacidade de solubilização de fosfato in vitro utilizando a mesma metodologia deste trabalho. Wang et al. (2014), utilizando outra metodologia verificou em uma estirpe de $B$. thuringiensis a capacidade de solubilização de $\mathrm{P}$ e eficácia na solubilização de $\mathrm{AlPO}_{4}$ (até $321 \mathrm{mg} \mathrm{mL}^{-1}$ ) in vitro.

Williams et al., (2012), estudando a estirpe de B. thuringiensis subsp. kurstaki ATCC33679 observou que esta produzia catecol um tipo de sideróforos em maiores quantidades quanto cultivada a uma temperatura de $25^{\circ} \mathrm{C}$, este resultado foi encontrado utilizando uma metodologia diferente.

Trabalhos relacionados à detecção da produção de metabólitos secundários com capacidade de promoção de crescimento vegetal por estirpes de B. thuringiensis são poucos, por isso as metodologias escolhidas para este trabalho são as mais utilizadas para os outros microrganismos.

Pedrinho (2009) atribuiu à baixa atividade da nitrogenase dos isolados testados ao fato de que estes foram purificados e cultivados por longo período em meio com fonte de nitrogênio, sendo que a regulação metabólica pode levar a perda da atividade enzimática, uma vez que a eficiência do processo de fixação de nitrogênio demanda muita energia do metabolismo bacteriano e que a qualidade e quantidade da fonte de carbono utilizada no meio de cultura podem influenciar a ausência da atividade enzimática da nitrogenase.

Assim, também se faz necessário realizar o teste de fixação de nitrogênio utilizando outras metodologias e a identificação molecular do gene nif- $H$ nas estirpes de $B$. thuringiensis avaliadas neste trabalho.

Resultados semelhante com estirpes de B. thuringiensis foi encontrado por Raddadi et al. (2008) que observou uma produção de AIA entre 1,53 a $9,71 \mu \mathrm{g} \mathrm{mL}^{-1}$, confirmando que estirpes de Bt são capazes de produzir AIA in vitro.

Bergamaschi (2006) verificou a produção de ácido indol-acético in vitro por diferentes isolados de bactérias do solo e obteve uma produção de AIA variando de 0,70 a $10,70 \mu \mathrm{g} \mathrm{mL}^{-}$ ${ }^{1}$. Silveira (2008) verificou uma produção de AIA entre 0,96 e 29, $45 \mu \mathrm{g} \mathrm{mL}^{-1}$, em diferentes isolados sendo alguns do gênero Bacillus. Trabalho realizado por Pedraza et al. (2004) obteve uma produção de AIA mais alta de $27,36 \mu \mathrm{g} \mathrm{mL} \mathrm{m}^{-1}$ com a estirpe UAP14 Azospirillum brasilense. Ambos os estudos foram realizados com a adição de L-triptofano e os resultados encontrados semelhantes a este trabalho. 
Valores semelhantes de produção de AIA foram encontrados por Kuss (2006) que verificou que todos os isolados testados produziram entre 2,79 e $13,47 \mu \mathrm{g} \mathrm{mL}^{-1}$, porém em um meio de cultura sem adição de L-triptofano. Confirmando que existem rotas diferentes para a produção de auxinas por microrganismos.

Beneduzi et al. (2008), verificou em isolados do gênero Bacillus que alguns produziam alta quantidade de AIA, além de produzir sideróforos e fixar nitrogênio e também promover uma aumento significativo nas raízes e parte aérea de arroz irrigado, bem como o acréscimo de $30 \%$ em relação a testemunha.

A quantidade de AIA produzida por bactérias depende da multiplicação bacteriana, atividade metabólica e da expressão dos genes que codificam as enzimas da rota biossintética de AIA (LAMBRECHT et al., 2000).

Das 100 estirpes analisadas 45 apresentaram amplicons esperados para todos os genes avaliados (Tabela 10), sendo que 71 estirpes apresentaram amplicons de tamanhos esperados para o gene codificador da enzima fosfatase ácida (Figura 13), 57 foram positivos para os genes da via de síntese de sideróforos (Figura 14).

Os genes envolvidos nas rotas de biossíntese do hormônio AIA se mostraram mais frequentes em estirpes de $\mathrm{Bt}$, sendo que das estirpes analisadas 91 foram positivos para a presença do gene ipdC (Figura 15), 97 para o genes iam1 e 93 para o gene iam2.

Tabela 10 - Caracterização molecular das estirpes de B. thuringiensis para a presença dos genes de promoção de crescimento vegetal

\begin{tabular}{|c|c|c|c|c|c|c|c|c|c|c|c|}
\hline Estirpes & $\begin{array}{c}\text { Gene } \\
\text { fosfatase } \\
\text { ácida }\end{array}$ & $\begin{array}{c}\text { Gene } \\
\text { sideróforos }\end{array}$ & $\begin{array}{l}\text { Gene } \\
\text { ipdC }\end{array}$ & $\begin{array}{l}\text { Gene } \\
\text { iam1 }\end{array}$ & $\begin{array}{l}\text { Gene } \\
\text { iam2 }\end{array}$ & Estirpes & $\begin{array}{c}\text { Gene } \\
\text { fosfatase } \\
\text { ácida }\end{array}$ & $\begin{array}{c}\text { Gene } \\
\text { sideróforos }\end{array}$ & $\begin{array}{l}\text { Gene } \\
\text { ipdC }\end{array}$ & $\begin{array}{l}\text { Gene } \\
\text { iam1 }\end{array}$ & $\begin{array}{l}\text { Gene } \\
\text { iam2 }\end{array}$ \\
\hline S29 & + & + & + & + & + & S1258 & + & + & + & + & - \\
\hline S40 & + & - & + & + & + & S1261 & + & - & + & + & + \\
\hline S62 & + & + & + & + & + & $\mathrm{S} 1262$ & + & + & + & + & + \\
\hline S93 & + & - & + & + & + & S1264 & + & + & + & + & + \\
\hline S165 & + & - & + & + & + & S1269 & - & - & + & + & + \\
\hline S202 & + & + & + & + & - & $\mathrm{S} 1271$ & - & - & + & + & + \\
\hline S392 & - & - & + & - & - & $\mathrm{S} 1272$ & - & - & + & + & - \\
\hline S406 & + & - & + & + & + & $\mathrm{S} 1275$ & - & - & + & + & + \\
\hline S407 & + & + & + & + & + & S1285 & - & - & + & + & + \\
\hline S408 & + & + & + & + & + & S1286 & - & - & + & + & + \\
\hline S411 & + & + & + & + & + & S1287 & + & - & + & + & + \\
\hline
\end{tabular}

(-) amostras que não apresentaram produto de amplificação para o gene testado; (+) amostras que apresentaram produto de amplificação para o gene testado. 
continuação Tabela 10 - Caracterização molecular das estirpes de B. thuringiensis para a presença dos genes de promoção de crescimento vegetal

\begin{tabular}{|c|c|c|c|c|c|c|c|c|c|c|c|}
\hline Estirpes & $\begin{array}{c}\text { Gene } \\
\text { fosfatase } \\
\text { ácida }\end{array}$ & $\begin{array}{c}\text { Gene } \\
\text { sideróforos }\end{array}$ & $\begin{array}{l}\text { Gene } \\
\text { ipdC }\end{array}$ & $\begin{array}{l}\text { Gene } \\
\text { iam1 }\end{array}$ & $\begin{array}{l}\text { Gene } \\
\text { iam2 }\end{array}$ & Estirpes & $\begin{array}{c}\text { Gene } \\
\text { fosfatase } \\
\text { ácida }\end{array}$ & $\begin{array}{c}\text { Gene } \\
\text { sideróforos }\end{array}$ & $\begin{array}{l}\text { Gene } \\
\text { ipdC }\end{array}$ & $\begin{array}{l}\text { Gene } \\
\text { iam1 }\end{array}$ & $\begin{array}{l}\text { Gene } \\
\text { iam2 }\end{array}$ \\
\hline S456 & - & + & - & + & - & S1288 & + & + & - & + & + \\
\hline S459 & + & + & + & + & + & S1289 & + & + & + & + & + \\
\hline S467 & + & - & + & + & + & S1290 & + & + & + & + & + \\
\hline S490 & + & + & + & + & + & S1291 & + & + & - & + & + \\
\hline S511 & + & + & + & + & + & S1292 & - & + & - & + & + \\
\hline S550 & + & - & - & + & + & S1295 & + & + & + & + & + \\
\hline S597 & + & + & + & + & + & S1301 & + & + & + & + & + \\
\hline S599 & + & + & + & + & + & S1304 & + & + & + & + & + \\
\hline S601 & + & - & + & + & + & S1307 & + & - & + & + & + \\
\hline S602 & + & + & + & + & + & S1342 & + & - & + & + & + \\
\hline S607 & + & - & + & + & + & S1365 & - & - & + & + & + \\
\hline S608 & - & - & + & + & + & $\mathrm{S} 1450$ & + & + & + & + & + \\
\hline S612 & + & + & + & + & + & S1457 & + & - & + & + & - \\
\hline S615 & + & + & + & + & + & S1530 & + & + & + & - & + \\
\hline S616 & + & + & + & + & + & S1704 & - & - & + & + & + \\
\hline S617 & + & - & + & + & + & S1806 & + & + & - & + & + \\
\hline S655 & + & + & + & + & + & S1905 & + & - & + & + & + \\
\hline S700 & + & + & + & + & + & S1974 & - & - & + & + & + \\
\hline S711 & + & + & + & + & + & S1975 & - & - & + & + & + \\
\hline S728 & + & + & + & + & + & S1976 & - & - & + & + & - \\
\hline S755 & + & + & + & + & + & S1977 & - & + & + & + & + \\
\hline S763 & + & + & + & + & + & S1978 & - & - & + & + & + \\
\hline S764 & + & + & + & + & + & S1979 & + & + & + & + & + \\
\hline S844 & - & + & + & + & + & S1982 & + & + & + & + & + \\
\hline S845 & + & + & + & + & + & S1983 & + & - & + & + & + \\
\hline S907 & + & - & + & + & + & S1984 & - & - & + & - & + \\
\hline S1026 & - & - & + & + & + & S1985 & - & - & - & + & + \\
\hline S1067 & + & + & + & + & + & S1986 & - & - & + & + & + \\
\hline S1089 & + & - & + & + & + & S1989 & + & - & + & + & + \\
\hline S1092 & + & + & + & + & + & S1990 & - & - & - & + & + \\
\hline S1094 & + & + & + & + & + & S1995 & - & - & + & + & + \\
\hline S1166 & - & - & + & + & + & S2001 & + & + & + & + & + \\
\hline S1167 & - & + & - & + & + & S2004 & + & + & + & + & + \\
\hline S1179 & - & - & - & + & + & S2005 & + & + & + & + & + \\
\hline
\end{tabular}

(-) amostras que não apresentaram produto de amplificação para o gene testado; (+) amostras que apresentaram produto de amplificação para o gene testado. 
continuação Tabela 10 - Caracterização molecular das estirpes de B. thuringiensis para a presença dos genes de promoção de crescimento vegetal

\begin{tabular}{cccccccccccc}
\hline Estirpes & $\begin{array}{c}\text { Gene } \\
\text { fosfatase } \\
\text { ácida }\end{array}$ & $\begin{array}{c}\text { Gene } \\
\text { sideróforos }\end{array}$ & $\begin{array}{c}\text { Gene } \\
\text { ipdC }\end{array}$ & $\begin{array}{c}\text { Gene } \\
\text { iam1 }\end{array}$ & $\begin{array}{c}\text { Gene } \\
\text { iam2 }\end{array}$ & Estirpes & $\begin{array}{c}\text { Gene } \\
\text { fosfatase } \\
\text { ácida }\end{array}$ & $\begin{array}{c}\text { Gene } \\
\text { sideróforos }\end{array}$ & $\begin{array}{c}\text { Gene } \\
\text { ipdC }\end{array}$ & $\begin{array}{c}\text { Gene } \\
\text { iam1 }\end{array}$ & $\begin{array}{c}\text { Gene } \\
\text { iam2 }\end{array}$ \\
\hline $\mathrm{S} 1185$ & + & + & + & + & + & $\mathrm{S} 2006$ & + & + & + & + \\
$\mathrm{S} 1191$ & + & + & + & + & + & $\mathrm{S} 2007$ & + & + \\
$\mathrm{S} 1192$ & - & + & - & + & + & $\mathrm{S} 2021$ & + & + & - & - & + \\
$\mathrm{S} 1225$ & + & + & + & + & + & $\mathrm{S} 2122$ & + & + \\
$\mathrm{S} 1257$ & - & - & - & + & + & $\mathrm{S} 2124$ & + & + & + & + \\
\hline
\end{tabular}

(-) amostras que não apresentaram produto de amplificação para o gene testado; (+) amostras que apresentaram produto de amplificação para o gene testado.

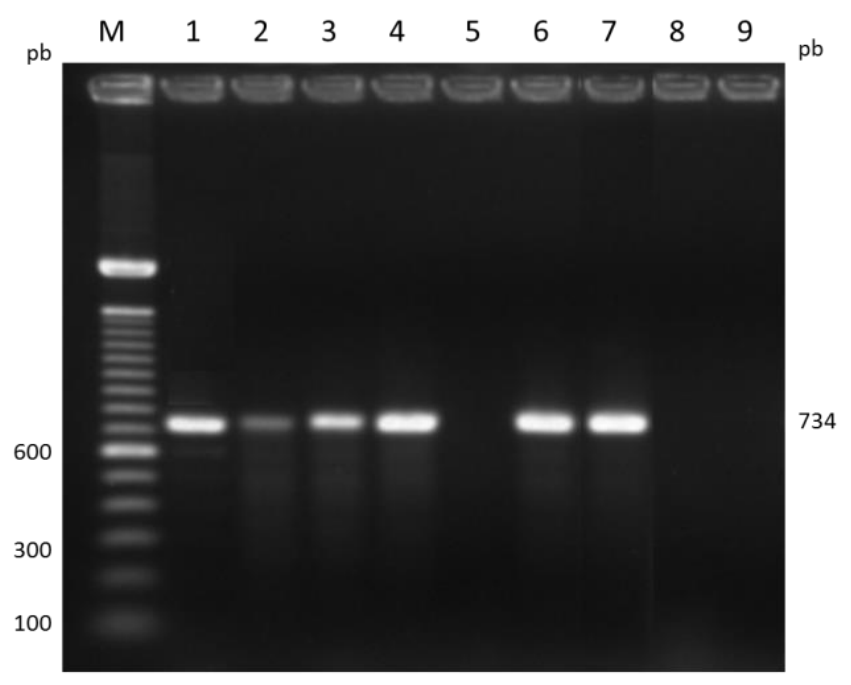

Figura 13 - Produtos de PCR obtidos para o gene fosfatase ácida. Eletroforese em gel de agarose $(1,5 \%)$ mostrando em M: marcador de peso molecular 100 bp DNA Ladder da Invitrogen; 1: S62; 2: S602; 3: S1191; 4: S1225; 5: S1271; 6: S1450; 7: S2124; 8: S1365; 9: controle negativo. 


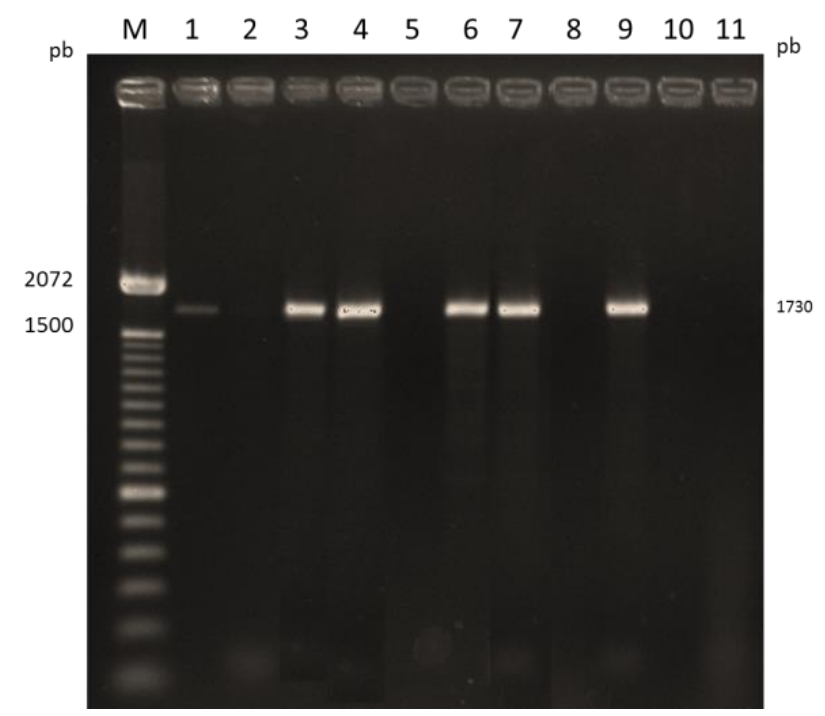

Figura 14 - Produtos de PCR obtidos para o gene biossíntese de sideróforos. Eletroforese em gel de agarose (1,5\%) mostrando em M: marcador de peso molecular 100 bp DNA Ladder da Invitrogen; 1: S62; 2: S608; 3: S1191; 4: S1225; 5: S1271; 6: S1450; 7: S2124; 8: S1365; 9: S1979; 10: S1985; 11: controle negativo.

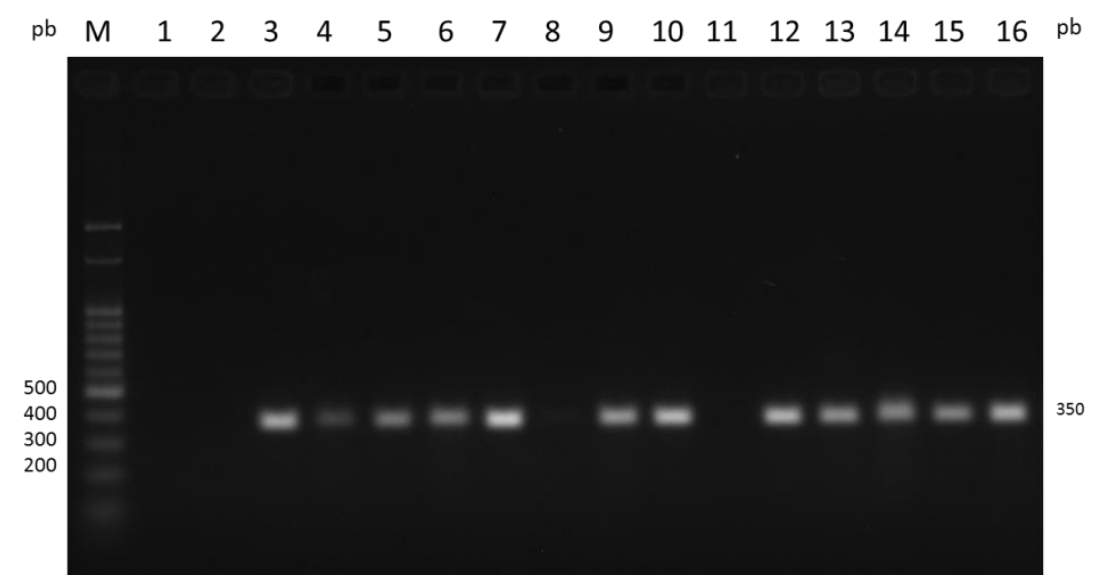

Figura 15 - Produtos de PCR obtidos para o gene ipdC. Eletroforese em gel de agarose (1,5\%) mostrando em M: marcador de peso molecular 100 bp DNA Ladder (Ludwig); 1: controle negativo; 2: S456; 3: S1089; 4: S1092; 5: S1094; 6: S1261; 7: S1264; 8: S1179; 9: S1983; 10: S1984; 11: S1985; 12: S1995; 13: S2001; 14: S2004; 15: S2005; 16: S2124.

Raddadi et al., (2008) verificaram em algumas estirpes de $B$. thuringiensis a presença dos genes de biossíntese de sideróforos, fosfatase ácida e ipdC, sendo que algumas estirpes foram produtoras de AIA in vitro mas não apresentaram amplicons para o gene ipdC, 
confirmando que a produção de AIA por bactérias pode ser também pelo presença do gene iam, corroborando os resultados encontrados neste trabalho.

A presença dos genes fosfatase ácida e sideróforos em estirpes de B. thuringiensis mostra a necessidade de novos testes in vitro utilizando outras metodologias, a fim de determinar a melhor forma de detectar a produção de metabólitos secundários por esta espécie.

Considerando-se que a expressão de um gene resulta em um custo metabólico e que a expressão de genes está sob controle de sinais endógenos e exógenos (SALEEM et al., 2010), são necessários estudos mais detalhados das condições ideais para a expressão dos genes de promoção de crescimento por estirpes de $B$. thuringiensis.

Trabalhos recentes mostram que estirpes de B. thuringiensis possuem potencial para serem utilizados como inoculante para a promoção de crescimento vegetal (WANG et al, 2014; SANTANA, 2014; TANUJA et al., 2013; BAI et al., 2003; GOMES et al., 2003). Este trabalho mostrou que além de produzir auxinas possui também potencial para solubilização de fosfato e produção de sideróforos pela presença de genes.

Araujo \& Guerreiro (2010) e Mehnaz \& Lazarovits (2006) demonstraram que o isolado que expressou a maior produção de AIA in vitro não foi a que promoveu o maior crescimento das plantas, demonstrando assim que é necessária uma avaliação das estirpes de B. thuringiensis em in vivo.

A identificação das características relacionadas com a promoção de crescimento vegetal por PGPR in vitro não apresenta necessariamente correlação com as interações in vivo (SMYTH et al., 2011), porém a caracterização bioquímica in vitro não podem ser negligenciadas devido ao grande número de isolados nos estudos de bioprospeção (BENEDUZI et al., 2008; GOES et al., 2012).

Bactérias capazes de promover o crescimento vegetal em culturas de importância econômica estão começando a ter uma relevância mais ampla nos sistemas de produção agrícola (SENTHILKUMAR et al., 2011).

Os resultados obtidos são promissores, no entanto há que se considerar a avaliação das estirpes em casa de vegetação e em campo, para poder afirmar o seu potencial como inoculante agrícola no Brasil. 


\section{CONCLUSÃO}

Existem estirpes de $B$. thuringiensis altamente tóxicas a $H$. armigera e com potencial para a promoção de crescimento vegetal. 


\section{CONSIDERAÇÕES FINAIS E PERSPECTIVAS}

- Estirpes de B. thuringiensis são efetivas contra H. armigera, sendo necessário realizar bioensaios para determinar a CL50 e realizar ensaios de sinergismos das proteínas presentes nas estirpes, além de identificar os possíveis receptores para as proteínas de Bt.

- B. thuringiensis são produtoras de auxina in vitro e algumas possuem os genes fosfatase ácida e sideróforos, mostrando a necessidade de realizar novos testes in vitro para a detecção da solubilização de fosfato e produção de sideróforos.

- Estirpes de B. thuringiensis possuem potencial para a promoção de crescimento vegetal, sendo necessário realizar ensaios em casa de vegetação para selecionar a melhor estirpe para teste em campo.

- Realizar testes simultâneos utilizando B. thuringiensis como promotor de crescimento e controle de $H$. armigera de forma sistêmica em culturas de interesse econômico. 


\section{REFERÊNCIAS}

ALI, A.; CHOUDHURY, R. A. Some biological characteristics of Helicoverpa armigera on chickpea. Tunisian Journal of Plant Protection, v. 4, n. 1, p. 99-106, 2009.

APAYDIN, O.C.; INAR, C., TURANLI, F., HARSA, S., GUNES, H. Identification and bioactivity of native strains of Bacillus thuringiensis from grain-related habitats in Turkey. Biol Control, v. 45, p. 21-28, 2008.

ARAUJO, F.F.; GUERREIRO, R.T. Bioprospecção de isolados de Bacillus promotores de crescimento de milho cultivado em solo autoclavado e natural. Ciênc. agrotec., Lavras, v. 34, n. 4 , p. $837-844,2010$.

AZZOUZ, H.; KEBAILI-GHRIBI, J.; DAOUD, F.; ABDELMALAK, N.; ENNOURI, K.; BELGUITH-BEN HASSAN, N.; TOUNSI, S.; ROUIS, S. Selection and characterization of Bacillus thuringiensis strains toxic against pyralid stored-product pests. Journal of applied entomology, 2014.

BAI, Y.X., ZHOU, X., SMITH, D.L. Enhanced Soybean plant growth resulting from coinoculation of Bacillus strains with Bradyrhizobium japonicum. Crop Science, v. 43, p. 1774-1781, 2003.

BEHERE, G.T.; TAY, W.T.; RUSSELL, D.A.; BATTERHAM, P. Molecular markers to discriminate among four pest species of Helicoverpa (Lepidoptera: Noctuidae). Bulletin of Entomological Research, v.98, p.599-603, 2008.

BEN-DOV, E.; ZARITSKY, A.; DAHAN, E.; BARAK, Z.; SINAI, R.; MANASHEROB, R.; KHAMRAEV, A.; TROITSKAYA, E.; DUBITSKY, A.; BEREZINA, N.; MARGALITH, Y. Microbiology Extended Screening by PCR for Seven cry-Group Genes from Field-Collected Strains of Bacillus thuringiensis. Applied and Environmental Microbiology, v. 63, 1997.

BENEDUZI, A.; PERES, D.; VARGAS, L. K.; BODANESE-ZANETTINI, M. H.; PASSAGLIA, L. M. P. Evaluation of genetic diversity and plant growth promoting activities of nitrogen-fixing Bacilli isolated from rice fields in south Brazil. Applied Soil Ecology, v. 39, p. 311-320, 2008. 
BERGAMASCHI, C. Ocorrência de bactérias diazotróficas associadas a raízes e colmos de cultivares de sorgo. Dissertação de Mestrado, Universidade Federal do Rio Grande do Sul, Porto Alegre, 2006.

BERRY, C.; O’NEIL, S.; BEN-DOV, E.; JONES, A.F.; MURPHY, L.; QUAIL, M.A.; HOLDEN, M.T.; HARRIS, D.; ZARITSKY, A.; PARKHILL, J. Complete sequence and organization of pBtoxis, the toxin-coding plasmid of Bacillus thuringiensis subsp. israelensis. Appl. Environ. Microbiol. v. 68, p. 5082-5095, 2002.

BRAVO, A.; GÓMEZ, I.; CONDE, J.; MUÑOZ-GARAY, C.; SÁNCHEZ, J.; ZHUANG, M.; GILL, S. S.; SOBERÓN, M. Oligomerization triggers differential binding of a pore-forming toxin to a different receptor leading to efficient interaction with membrane microdomains. Biochemistry Biophysical Acta, v. 1667, p. 38-46, 2004.

BRAVO, A.; LIKITVIVATANAVONG, S.; GILL, S.S.; SOBERÓN, M. Bacillus thuringiensis: a story of a successful bioinsecticide. Insect Biochem Mol Biol, v. 41, p. 423431, 2011.

BRAVO, A.; SARABIA, S.; LOPEZ, L.; ONTIVEROS, H.; ABARCA, C.; ORTIZ, A.; ORTIZ, M.; LINA, L.; VILLA-LOBOS, F.J.; GUADALUPE, P.NUNEZ-VALDEZ, M.E.; SOBERÓN, M.; QUINTERO, R. Characterization of cry genes in Mexican Bacillus thuringiensis strain collection. Applied and Environmental Microbiology, v.64, p. 49654972, 1998.

BUTT, B. A., CANTU, E. Sex determination of lepidopterous pupae, ARS. United States Departament of Agriculture, Washington. v. 7, p. 33-75, 1962.

CATTELAN, A.J. Métodos quantitativos para determinação de características bioquímicas e fisiológicas associadas com bactérias promotoras de crescimento vegetal. Londrina: Embrapa Soja, p. 36, 1999 (Embrapa Soja. Documentos, 139).

CERON, J.; ORTIZ, A.; QUINTERO, R.; GUERECA, L.; BRAVO, A. Specific PCR primers directed to identify cryI and cryIII genes within a Bacillus thuringiensis strain collection. Applied and Environmental Microbiology, Birmingham, v. 61, p. 3826-3831, 1995 
CHAKRABARTI, S.K.; MANDAOKAR, A.; KUMAR, P.A.; SHARMA, R.P. Efficacy of lepidopteran specific $\delta$-endotoxins of Bacillus thuringiensis against Helicoverpa armigera. $\mathbf{J}$. Invertebr. Pathol, v. 72, p. 336-337, 1998.

CRICKMORE, N.; ZEIGLER, D. R.; SCHNEPF, E.; VAN RIE, J.; LERECLUS, D.; BAUM, J.; BRAVO, A.; DEAN, D. H. Bacillus thuringiensis toxin nomenclature. Disponível em: http://www.biols.susx.ac.uk/Home/Neil_Crickmore/Bt/. Acesso em: 30 janeiro 2015.

CRICKMORE, N.; ZEIGLER, D.R.; FEITELSON, J.; SCHNEPF, E.; VAN RIE, J.; LERECLUS, D.; BAUM, J.; DEAN, D.H. Revision of the nomenclatura for the Bacillus thuringiensis pesticidal Crystal proteins. Microbiol. Molec. Biol. Rev. v. 62, p. 807-813, 1998.

CZEPAK, C.; ALBERNAZ, K.C.; VIVAN, L.M.; GUIMARÃES, H.O.; CARVALHAIS, T. Primeiro registro de ocorrência de Helicoverpa armigera (Hübner) (Lepidoptera: Noctuidae) no Brasil. Pesquisa Agropecuária Tropical, v.43, p.110-113, 2013.

FELESTRINO, E.B. Isolamento e caracterização bioquímica e molecular de microrganismo associados à interação Langsdorffia hypogaea - Hospedeira-Rizosfera. Dissertação de Mestrado. Universidade Federal de Ouro Preto, Ouro Preto, 2013.

GOES, K.C.G.P.; FISHER, M.L.C.; CATTELAN, A.J.; NOGUEIRA, M.A.; CARVALHO, C.G.P.; OLIVEIRA, A.L. M. Biochemical and molecular characterization of high population density bacteria isolated from sunflower. Journal of Microbiology and Biotechnology, v. 22, p. 437-447, 2012.

GOMES, A.M.A.; MARIANO, R.L.R.; SILVEIRA, E.B.; MESQUITA, J.C.P. Isolamento, seleção de bactérias e efeito da utilização de Bacillus spp. na produção de mudas orgânicas de alface. Horticultura Brasileira, Brasília, v. 21, n. 4, p. 699-703, outubro-dezembro 2003.

GORDON, S.A.; WEBER, R.P. Colorimetric estimation of indoleacetic acid. Plant Physiology, v. 26, p. 192-195, 1950.

GREENE, G.L.; LEPPLA, N.C.; DICKERSON, W.A. Velvetbean caterpillar: a rearing procedure and artificial medium. Journal of Economic Entomology, v. 69, n. 4, p. 487-488, 1976. 
GUERCHICOFF, A.; DELECLUSE, A.; RUBINSTEIN, C. The Bacillus thuringiensis cyt toxins Genes for Hemolytic Endotoxins Constitute a Gene Family. Applied and Environmental Microbiology, v. 67, n. 3, p. 1090-1096, 2001.

HARRISON, R.L.; BONNING, B.C. Genetic engineering of biocontrol agents for insects. In: Biology and biotechnology control of insect pests. Edited by Jack E. Rechaige and Nancy A. Rechagl. By CRC Press LLC. p. 243-280, 2000.

HOFTE, H., WHITELEY, H.R. Insecticidal crystal protein of Bacillus thuringiensis. Microbiol. Rev. v.53, n.2, p. 242-255, 1989.

IBARRA, J.; RINCÓN, C.; ORDÚZ, S.; NORIEGA, D.; BENINTENDE, G.; MONNERAT, R.G.; REGIS, L.; OLIVEIRA, C.M.F.; LANZ, H.; RODRIGUEZ, M.H.; SÁNCHEZ, J.; PEÑA, G.; BRAVO, A. Diversity of Bacillus thuringiensis strains from Latin America with insecticidal activity against different mosquito species. Applied and Environmental Microbiology, v. 69, p. 5269-5274, 2003.

JAQUET, F.; HUTTER, R.; LUTHY, P. Specificity of Bacillus thuringiensis DeltaEndotoxin. Applied And Environmental Microbiology, p. 500-504, 1987.

KUSS, A.V. Fixação de nitrogênio por bactérias diazotróficas em cultivares de arroz irrigado. Tese de Doutorado. Universidade Federal de Santa Maria, Santa Maria, 2006.

LAEMMLI, U.K. Cleavage of structural proteins during the assembly of the head of bacteriophage T4. Nature: 227, 680-685, 1970.

LAMBRECHT, M.; OKON, Y.; BROEK, A.V.; VANDERLEYDEN, J. Indole-3-acetic acid: a reciprocal signaling molecule in bacteria-plant interactions. Trends Microbiol, v.8, p. 298$300,2000$.

LECADET, M.M.; CHAUFAUX, J.; RIBIER, J.E.; LERECLUS, D. Construction of novel Bacillus thuringiensis strains with diferente insecticidal activities by transduction and transfomation. Applied and Environmental Microbiology, v. 58, p. 840-849, 1991.

LI, H.; BOUWER, G. Evaluation of the synergistic activities of Bacillus thuringiensis Cry proteins against Helicoverpa armigera (Lepidoptera: Noctuidae). Journal of Invertebrate Pathology, v. 121, p. 7-13, 2014. 
LIAO, C.; HECKEL, D.G.; AKURST, R. Toxicity of Bacillus thuringiensis insecttidal proteins for Helicoverpa armigera and Helicoverpa punctigera (Lepidoptera: Noctuidade), major pests of cotton. Journal of Invertebrate Pathology, 2002, volume 80, p 55-63.

MACEDO, C.L.; MARTINS, E.S.; MACEDO, L.L.P.; SANTOS, A.C.; PRAÇA, L.B.; GÓIS, L.A.B.; MONNERAT, R.G. Seleção e caracterização de estirpes de Bacillus thuringiensis eficiente contra Diatrea saccharalis (Lepidoptera: Crambidae). Pesq. Agropec. Bras., v.47, n.12, p.1759-1765, 2012.

MEHNAZ, S.; LAZAROVITS, G. Inoculation effects of Pseudomonas putida, Gluconacetobacter azotocaptans and Azospirillum lipoferum on corn plant growth under greenhouse conditions. Microbial Ecology, v.51, p.326-335, 2006.

MELlATI, V.; BATISTA, A.; DEMO, C.; PRAÇA, L.; BROD, C.; MONNERAT, R.G. Determinação da susceptibilidade de Spodoptera frugiperda à diferentes subspecies de Bacillus thuringiensis. Brasília: Embrapa Recursos Genéticos e Biotecnologia. Boletim de Pesquisa e Desenvolvimento n. ${ }^{\circ} 88,2005$.

MENSAH, R. K. Supresssion of Helicoverpa spp. (Lepidoptera: Noctuidae) oviposition by use of the natural enemy food supplement Envirofeast. Australian Journal of Entomology, v. 35, n. 4, p. 323-329, Nov. 1996.

MONNERAT, R.G., PRAÇA, L.B., MARTINS, E.S., DUMAS, V.D., RAMOS, F.R., BERRY, C. Atividade de toxinas individuais de Bacillus thuringiensis serovar israelensis contra larvas do Bicudo do Algodoeiro, Anthonomus grandis (Coleoptera: Cuculionidae). Brasília: Embrapa Recursos Genéticos e Biotecnologia. Boletim de Pesquisa e Desenvolvimento n. ${ }^{\circ} 141,12$ p., 2006.

MONNERAT, R.G.; BATISTA, A. C.; MEDEIROS, P. T. S.; MARTINS, E.; MELATTI, V.; PRAÇA, L.; DUMAS, V.; DEMO, C.; GOMES, A. C. M.; FALCAO, R.; BROD, C. S.; SILVA-WERNECK, J. O.; BERRY, C. Characterization of Brazilian Bacillus thuringiensis strains active against Spodoptera frugiperda, Plutella xylostella and Anticarsia gemmatalis. Biological Control, v. 41, p. 291-295, 2007. 
MONNERAT, R.G.; SILVA, S.F.; SILVA-WERNECK, J.O. Catálogo do banco de germoplasma de bactérias do gênero Bacillus. Brasília: Embrapa-Cenargen, 2001. 65p. (Documentos, 60)

PEDRAZA, R.O.; RAMIREZ-MATA, A.; XIQUI, M.L.; BACA, B.E. Aromatic amino acid aminotransferase activity and indole-3-acetic acid production by associative nitrogen-fixing bacteria. FEMS Microbiol Lett, v. 233(1), p. 15-21, 2004.

PEDRINHO, E.A.N. Isolados e caracterização de bactérias promotoras de crescimento em milho (Zea mays). Tese de doutorado. Universidade Estadual Paulista, Jaboticabal, 2009.

RADDADI, N.; CHERIF, A.; BOUDABOUS, A.; DAFFONCHIO, D. Screening of plant growth promoting traits of Bacillus thuringiensis. Annals of Microbiology, v.58, n.1, p.47$52,2008$.

RODRIGUES NETO, J.; MALAVOLTA JUNIOR, V. A.; VICTOR, O. Meio simples para o isolamento e cultivo de Xanthomonas campestris pv. citri tipo B. Summa Phytopathologica, Campinas, v. 12, n. 1-2, p. 16, 1986.

SALEEM, M.; LAMKEMEYER, T.; SCHÜTZENMEISTER, A.; MADLUNG, J.; SAKAI, H.; PIEPHO, H. P.; NORDHEIM, A.; HOCHHOLDINGER, F. Specification of cortical parenchyma and stele of maize primary roots by asymmetric levels of auxin, cytokinin, and cytokinin-regulated proteins. Plant Physiology, v. 152, p. 4-18, 2010.

SANTANA, F.S.C. Bacillus thuringiensis como endofíticos em algodão: avaliação na promoção de crescimento e controle de Spodoptera frugiperda. Dissertação de Mestrado, Universidade de Brasília, Brasília, 2014.

SELDIN, L.; VAN ELSAS, I. D.; PENIDO, E. G. C. Buciffus azotofixans sp. nov., a nitrogenfixing species form Brazilian soils and grass roots. Internacional Journal of Systemic Bacteriology, v. 34, p. 451-456, 1984.

SENTHILKUMAR, M.; ANANDHAM, R.; MADHAIYAN, M.; VENKATESWARAN, V.; AS, T. Endophytic bacteria: perspectives and applications in agricultural crop production, In: D.K. Maheshwari (Ed.), Bacteria in Agrobiology: Crop Ecosystems, vol. XII, Springer, p. 61-96, 2011. 
SHOJAADDINI, M.; LOPEZ, M.J.; MOHARRAMIPOUR, S.; KHODABAN- DEH, M.; TALEBI, A.A.; VILANOVA, C.; LATORRE, A.; PORCAR, M.A. Bacillus thuringiensis strain producing epizootics on Plodia interpunctella: a case study. J Stored Prod Res, v. 48, p. 52-60. 2012.

SILVA-WERNECK, J.O.; MONNERAT, R. Metodologias para caracterização de isolados de Bacillus thuringiensis. Brasília: Embrapa-Cenargen, 2001. 5p. (Circular Técnica, 10).

SILVEIRA, E.L. Inoculações de bactérias promotoras de crescimento no cultivo de arroz em solução nutritiva. Tese de Doutorado. Universidade Estadual Paulista, Jaboticabal, 2008.

SMYTH, E. M.; MCCARTHY, J.; NEVIN, R.; KHAN, M. R.; DOW, J. M.; O’GARA, F.; DOOHAN, F. M. In vitro analyses are not reliable predictors of the plant growth promotion capability of bacteria; a Pseudomonas fluorescens strain that promotes the growth and yield of wheat. Journal of Apllied Microbiology, v. 111, p. 683-692, 2011.

SYLVESTER-BRADLEY, R.; ASAKAWA, N.; LATORRACA, S.; MAGALHÃES, F. M. M.; OLIVEIRA, L. A.; PEREIRA, R. M. Levantamento quantitativo de microrganismos solubilizadores de fosfato na rizosfera de gramíneas e leguminosas forrageiras na Amazônia. Acta Amazônica, v.1, p.12-22, 1982.

TAILOR, R.; TIPPET, J.; GIBB, G.; PELlS, S.; PIKE, D.; JORDAN, L.; ELY, S. Identification and characterization of a novel Bacillus thuringiensis $\delta$-endotoxin entomocidal to coleopteran and lepidopteran larvae. Molecular Microbiology, v. 6, n. 9, p. 1211-1217, 1992.

TANUJA, R.; BISHT, S.C.; MISHRA, P.K. Ascending migration of endophytic Bacillus thuringiensis and assessment of benefits to different legumes of N.W. Himalayas. European Journal of Soil Biology, v.56, p.56-64, 2013.

WANG. T.; LIU, M.; LI H. f Acta Agriculturae Scandinavica, Section B - Soil \& Plant Science. v. 64, 2014

WILLIAMS, K.M.; MARTIN, W.E.; SMITH, J.; WILLIAMS, B.S.; GARNER, B.L. Production of protocatechuic acid in Bacillus thuringiensis ATCC33679. Int. J. Mol. Sci. v.13, p.3765-3772, 2012. 
XUE, J.L.; CAI, Q.-X.; ZHENG D.-S.; YUAN, Z.-M. The synergistic activity between Cry1Aa and Cry1C from Bacillus thuringiensis against Spodoptera exigua and Helicoverpa armigera. Letters in Applied Microbiology, 2005, 40, 460-465. 